Papers and Proceedings of the Royal Society of Tasmania,. Volume 112, 1978

(ms. received 5.8.1975)

\title{
SOME COMMON COHPONENTS OF THE PLANKTON OF THE SOUTHEASTERN COASTAL WATERS OF TASMANIA
}

\author{
by Nyan Taw \\ Department of Zoology, University of Tasmania
}

(with 99 text-figures)

\section{ABSTRACT}

Zooplankton species found during studies of the zooplankton of the southeastern coastal waters of Tasmania are recorded, and discussed taxonomically where appropriate. A brief account is given of the distribution of the 71 pelagic copepods, eight euphausids, one sergestid, 11 chaetognaths and seven pelagic tunicates. Except for two copepod species which are assigned only to a genus, the remaining are positively identified to species level. Amongst the species recorded, 22 copepods are new to Australian waters whereas 38 copepods, one euphausid and two chaetognaths are new records for Tasmanian waters. Keys to the copepod genera and species are also given.

\section{INTRODUCTION}

The knowledge of Tasmanian marine plankton fauna, especially the copepods, is based almost exclusively upon materials collected by a few expeditions. The earliest contribution was from the Australian Antarctic Expedition (1911-1914) which operated a station off Maria Island and a station off the west coast of Tasmania. The Discovery Investigation Expeditions (1925-1927) operated a few stations around Tasmanian waters and another two stations were occupied by the British, Australian and New Zealand Antarctic Research Expedition (1929-1931) in southern Tasmanian waters.

Thomson (1947) and Thompson (1948) reported on the extensive studies of chaetognaths and pelagic tunicates respective1y, found in the plankton hauls made by the C.S.I.R. Research Vessel "Warren" where the stations extended from the southern Queens1and coast to South Australia and Tasmania.

Recently, the knowledge of Tasmanian euphausids was supplemented by a few stations operated around Tasmanian waters by Bradbury (1972) during his study on the seasonal distribution of Euphausiidae in the southern ocean adjacent to Australia.

Da11 (1957a \& b, 1958) reported the distribution of zooplankton, main1y copepods, from the north and northeast of Tasmania. Kott (1957) reported the occurrence and composition of zooplankton on the material collected off New South Wales coast and Tasman Sea. Ong (1967) studied the zooplankton on the Derwent Estuary and recorded a few species.

The most extensive work on Australian marine plankton was done by Dakin and Colefax $(1933,1940)$ on the plankton samples collected off the coast of New South Wales.

Apart from these few studies, no detailed or lengthy study has been made on the Tasmanian marine and estuarine zooplankton. In particular, the copepod fauna, an important part of the marine plankton has not been investigated in detail.

The present paper provides a list, with figures, and key, of the major and common zooplankton groups found in the samples collected in the southeastern coastal waters of Tasmania. A more detailed account of their distribution has been presented by Nyan Taw (1975b). 


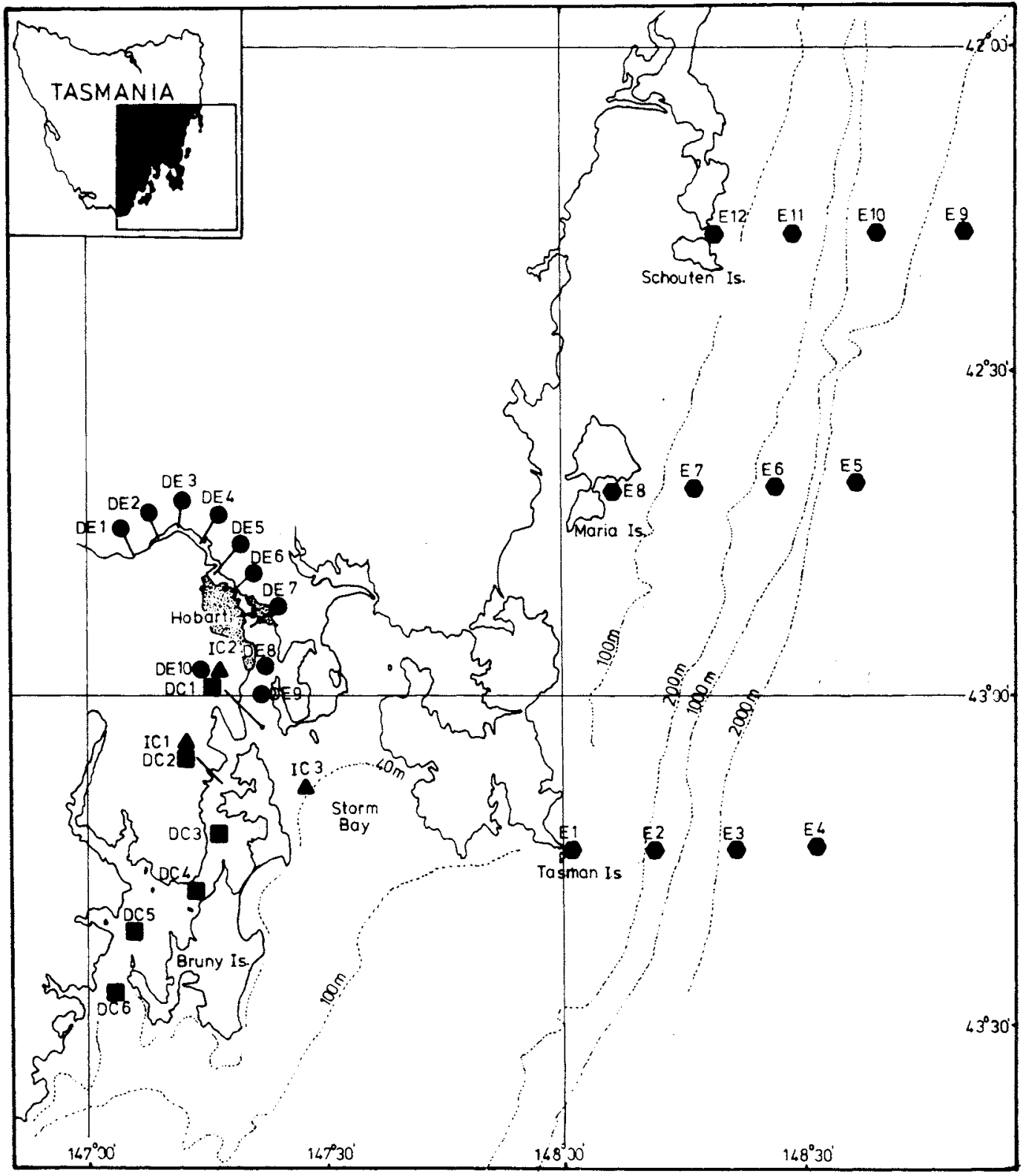

(E) - indicates east-coast day stations: samples taken over a period of 2 years (June 1971 to Nay 1973) during which a total of 10 cruises were made approximately 1 to 3 months apart.

(IC) - indicates inshore coastal day and night stations: sampled once a

(DC) - indicates D Entrecastreaux Channel day stations: sampled once every 2 months for a period of a year (August 1972 to July 1973).

$(D E)$ - indicates Derwent Estuary day stations: sampled during 2 cruises (October 1973 and April 1974).

FIG. 1. - Zooplankton stations in the southeast coastal waters of Tasmania. 
Source of Material and Methods

The systematic account of the zooplankton presented in this paper was from the zooplankton samples collected in the southeastern coastal waters of Tasmania (fig. 1). The plankton samples were collected for four different studies, namely:

i. Water masses study off the east coast of Tasmania - stations indicated by the prefix 'E' (day stations; samples taken over a period of 2 years - June 1971 to May 1973 - during which a total of 10 cruises were made approximately 1 to 3 months apart),

ii. A comparative study on the seasonal diurnal vertical distribution of zooplankton in the inshore coastal waters of southeastern Tasmania - stations indicated by the prefix 'IC' (day and night stations; samples once a month for a period of a year August 1971 to July 1972),

iii. A study on the zooplankton of D'Entrecasteaux Channel - stations indicated by the prefix 'DC' (day stations; sampled once every 2 months for a period of a year August 1972 to July 1973), and,

iv. A study on the zooplankton of the Derwent Estuary - stations indicated by the prefix 'DE' (day stations; sampled during 2 cruises - October 1973 and April 1974).

Except for the comparative study of zooplankton in the inshore coastal waters, oblique tows were made in collecting the plankton samples: bottom to surface in D'Entrecasteaux Channel and Derwent Estuary zooplankton studies and $50 \mathrm{~m}$ to surface in shallow water stations and $100 \mathrm{~m}$ to surface in deep water stations in the East Coast water masses study. The plankton samples were preserved in approximately 5\% formalin after each collection.

The East Coast water mass study plankton collections were made from F.R.V. "Penghana". The Zoology Department Research vessel "Neotrigonia" was used to collect the plankton samples for the remaining studies.

For taxonomic work on planktonic crustacea, the formalin preserved animal was immersed in a liquid mixture of glycerine and water having the ratio of $1: 2$ respectively. The mixed media containing the animal was kept in an oven $\left(60^{\circ} \mathrm{C}\right)$ for about an hour, during which time the water in the mixed liquid evaporated and the animal was cleared and left in the pure glycerine. Thus the whole animal may be observed and studied from several angles.

The animal was dissected in the glycerine medium with a pair of minutent needles. The dissected parts were mounted in polyvinyl alcohol mounting fluid for detailed microscopic examination. A camera lucida was used to draw the animals and the parts dissected. Both compound and phase contrast microscopes were used in examining the whole animal and the parts dissected.

For salps and chaetognaths a dark-field condenser (Heron 1969) was used in identifying the specimens.

To be able to present a brief account of the occurrence of the zooplankton species, the study area is divided into four regions. The east coast area is divided according to the nomenclature given by Miller (1950) as coastal and oceanic, the oceanic waters being the region beyond $200 \mathrm{~m}$ depth, and as such the stations in that area will be referred to as 'Oceanic' in giving the occurrence of a species. The remaining stations in the east coast is referred to as 'Coastal'. The stations occupied during the D'Entrecasteaux Channel zooplankton study and the comparative study of zooplankton in the inshore coastal waters are referred to as 'Inshore Coastal', due to the fact that the area is well inside the coastal region. The Derwent Estuary zooplankton study stations are divided according to Guiler's (1955) zonation such as freshwater to tidal and marine, in the present study they will be referred to as 'Estuarine' and 'Inshore Coastal' respectively. 
The following 1 ist shows the stations in their appropriate regions:

OCEANIC - E2, E3, E4, E5, E6, E9 \& E10.

COASTAL $\quad-E 1, E 7, E 8, E 11$, E E12.

INSHORE COASTAL - IC1, IC2, IC3, DC1, DC2, DC3, DC4, DC5, DC6, DE7, DE8, DE9, \& DE10. ESTUARINE - DE1, DE2, DE3, DE4, DE5, \& DE6.

If a species occurred five times or less, the stations where it was found are given, but if it occurred more than five times it will be assigned to the appropriate region or water mass.

\section{Systematics}

A total of 98 zooplankton species were recorded. The species consisted of 71 copepods, eight euphausids, one sergestid, 11 chaetognaths and seven pelagic tunicates. Except for two copepod species which were assigned only to a genus, the remaining were positively identified to specific level. Of all the species recorded, 22 copepod species are new to the Australian waters whereas 38 copepods, one euphausid and two chaetognaths are new records for Tasmanian waters.

The keys to copepod genera and species given are designed for the identification of the genera and species found in the present study area of the southeastern coastal waters of Tasmania. The key to the copepod genera was based on the keys given by Wilson (1932), Rose (1933), Dakin and Colefax (1940) and Bradford (1972).

The previous distributional records of the species given are derived from studies in the southern ocean, Australian region and major studies on the other oceans.

\section{COPEPODA}

Key to the Genera of Order Calanoida

1. Endopodites of 1 egs 3 and 4,3 segmented $\ldots \ldots \ldots 2$

Endopodites of legs 3 and 4,2 segmented $\ldots \ldots \ldots 35$

2. Endopodites of 1 st $1 \mathrm{eg}, 3$ segmented $\ldots \ldots \ldots 3$

Endopodites of $1 \mathrm{st} 1 \mathrm{eg}, 2$ segmented $\ldots \ldots \ldots 13$

Endopodites of 1 st $1 \mathrm{eg}, 1$ segmented $\ldots \ldots \ldots 17$

3. Circular brown knob on right or left side of 1 st. segment of metasome; 5 th leg uniramous, 2-4 segments in female, 5 segments in male and asymmetrical.

No such circular brown knob

$$
\text { ....... } 4
$$
Fleuromama. of \&

4. Basal segment of endopodite of 2 nd. 1 eg deeply invaginated; with spines on the side of the invagination; female 5th. leg uniramous; 3-4 segments; male 5th. legs, 5 segments.

No such invagination or spines present $\ldots \ldots \ldots \ldots$

$$
\text { Metridia. of } \& \text { o }
$$

5. 3rd expodite of $3 \mathrm{rd}$. and $4 \mathrm{th}$. legs with one lateral spine, one at distal corner, and one terminal $\ldots \ldots \ldots 6$ 3 rd. expodite of $3 \mathrm{rd}$. and 4 th 1 egs with two lateral spines, one distal, and one terminal $\ldots \ldots \ldots 10$

6. Terminal spines of $3 \mathrm{rd}$. expodites of $3 \mathrm{rd}$ and 4 th 1 egs with both margins smooth $\ldots \ldots \ldots 7$ Terminal spines of this segment with one or both margins pectinate, denticulate, or setaceous $\ldots \ldots . . . .99$

7. Forehead conical, slightly crested, male 5th. legs prehensile. Forehead not conical or crested $\ldots \ldots \ldots$.... 8 Calanoides. of

8. Inner margin of $1 \mathrm{st}$. basipodite of $5 \mathrm{th}$. 1egs smooth; 2 nd. legs, with a recurved spine at the outer distal border of the 1st expodite segment; left 5 th. 1 eg in 
Nyan Taw

male modified; 1st. antennae exceeds the body length by a few segments or exceeds the body length by half. Neocalanus.

$\sigma^{A} \&$ \& Inner margin of 1st basipodite of 5 th legs smooth; 2nd legs, without a recurved spine at the outer distal border of the 1st. exopodite segment; left 5 th. 1 eg in male modified; 1st antennae exceeds the body length by half.

Mesocalanus.

$\sigma^{\pi} \&$ \&

Inner margin of 1 st basipodite of 5 th legs serrated (toothed); 2nd. 1egs without a recurved spine at the outer distal border of the 1st. exopodite segment; $1 \mathrm{eft}$ 5 th leg little modified in males; 1st antennae exceeds the body length by a few segments. catanus.

$\sigma^{7} \&$ \&

9. 5th legs uniramous in female, 3 or 4 segmented; biramous in male, the endopod ${ }^{+}$ rudimentary or 1 acking, exopod 2 or 3 segmented, right uncinate. Pseudodioptomis. of \&

5 th. legs biramous in both sexes; asymmetrical with well developed endopodite ${ }^{+}$in male; symmetrical, a curved serrated or smooth spine-1ike process on the inner middle segment of endopodite; 1st. basipodite of $4 \mathrm{th}$. leg with a sword-1ike spine in female (except in $G$. symetricus). Gladioferens of \& 5 th legs biramous in both sexes; asymmetrical in male exopodite 3 segmented forming a long narrow curved claw; symmetrical in female with toothed process on the inner middle segment of endopodite, two lobes on the 1 ast metasomal segment projected posteriorly in females. Boeckelza.

of

10. Left and sometimes right furcal ramus with one seta thicker than the others and greatly elongated; rami of 2 nd. antennae approximately equal 1 ength; middle segment of the exopodite of 5 th. legs in female with smooth inner spine; 2nd basipodite of right 5th. leg in male with sausage-shaped process; all setae of 2nd maxilla transformed into stout spines. Heterorhabdus. Setae of furcal rami neither thicker nor elongated $\ldots . . . . .11$

11. Females only; 1 st antennae symmetrical; 5 th. legs biramous, symetrical with plumed setae, and with rami 3 segmented; middle segment of exopodite of 5 th. legs with large inner spine; end segment with denticulate terminal spine, exopodite of 2nd. antennae 6 segmented.

Males only; 1st. antennae asymmetrical

Centropages. .........

12

12. Right 1st. antenna modified, geniculate; 1eft exopodite of 5 th. leg 2 segmented, right 3 segmented; endopodites symmetrical and 3 segmented; exopodite of 2 nd antenna 6 segmented, its basal segment often very short. Centropages.

Left 1st. antenna geniculate; 5th. legs asymmetrical, rami of left 3 segmented, the right 2 segmented; distal segment of right exopodite shuts down against proximal one to form a chela. Lucicutia.

13. Both rami of 5 th. legs symmetrical, 3 segmented and armed with plumose setae; exopod of 1st. antennae 8 segmented; 5 th. and 6 th. metasomal segments fused. Lucicutia. 오 5th. legs asymnetrical in both sexes; uniramous and 3 segmented in female; ${ }^{+}$eft leg uniramous, right biranous both strongly modified in male; 2nd. maxilla bears unusually long, strong denticulate spine which reaches forward as far as the eyes. $\quad$ SuZcamus. of \& Endopodite of $5 \mathrm{th}$. legs rudimentary or lacking; sometimes the whole leg is wanting on one or both sides. $\ldots \ldots \ldots \ldots 14$

14. Furcal rami only three times as long as wide or 1 ess; middie segments of endopodite of $3 \mathrm{rd}$ and 4 th legs with 2 setae and end segment with 7 setae ........ 15

Furcal rami as above; middle segment of endopodite of $3 \mathrm{rd}$. and 4 th. legs with one seta, end segment with 5 setae ........ 16

15. End seta of exopodite of 2 nd., 3rd. and 4 th. legs with its outer margin smooth in both sexes; outer margin of 2 nd., $3 \mathrm{rd}$. and 4 th. 1 eg of exopodite not toothed; 5 th legs uniramous; 3 or 4 segmented in females; in male, right 5 th. leg 4 segmented, left 5 segmented. 
Outer margin of the exopodite of 2 nd, 3rd. and 4th. legs toothed; 5 th. legs present in both male and female, 2 segmented and uniramous in female, in male, right leg 2 segmented, left leg 5 segmented; exopodite of 2 nd. antenna shorter than endopodite and 7 segmented. Paracalanus. of $q$

16. Exopodite of 1st. legs 2 segmented; female 5 th. legs uniramous, 3 segmented; left male 5 th. leg biramous, right uniramous with only one segment. Rhinealanus. of \& Exopodite of 1st. legs 3 segmented; 5 th. legs absent in females; endopodite of 2nd. antenna longer than exopodite; end spines of the exopodite of 2 nd. to 4 th. legs with smooth margins; male 5th. legs uniramous. Eucalanus. of \&

17. Endopodite of 2 nd. legs 3 segmented; exopodite of 2 nd. antennae half as long as endopodite; abdomen 3 segmented in female, 4 segmented in male; 5 th. legs alike in both sexes, symmetrical and 5 segmented. Endopodite of 2 nd. 1 eg 2 segmented Endopodite of 2 nd. 1 eg 1 segmented Mecynocera. of \&

18. Posterior surface of the rami of 3 rd and 4 th. legs armed with spines ............. 13

Posterior surface of the rami of 3 rd and 4 th legs smooth ... 23

19. Metasome wide, always globular in shape Phaenna Metasome elongated, elliptical in shape $\ldots \ldots \ldots \ldots . . .20$

20. 5th. legs present, males on $1 y \quad \ldots \ldots \ldots \ldots 21$ 5 th legs absent, females only $\ldots \ldots \ldots \ldots 22$

21. 5th. legs biramous on one side on 1y; 2nd. maxilla with worm-like appendages without spiny hooked setae; squat and thick stylet. Scolecithrix. 5 th legs biramous on both sides; $1 \mathrm{eft}$ endopodite of 5 th. leg much 1onger than exopodite with one segment, right endopodite with one segment.

$$
\text { Racovitzonus. }
$$

22. 3rd. exopodite segment of 2 nd, $3 \mathrm{rd}$. and 4 th 1 egs with 4 internal setae; posterior corner of metasome rounded; genital segment projecting ventrally.

\section{Scolecithmix.}

3 rd, exopodite segment of 2nd., 3rd. and 4th. 1egs with 4 internal setae; genital segment without ventral projection; rostrum with two small points; second maxilla with special terminal setae.

Racovitzanus. of

23. Basal segments and exopodite of 2 nd. and 3rd. legs much broader than in 4th. 1eg; distal margin of 2 nd. basal segment with strong teeth; terminal setae of exopodite of $3 \mathrm{rd}$. 1eg broad and blade-1ike; female 5th. 1egs uniramous, 3 segmented; male 5 th legs uniramous, left 5 segmented, right 1 to 3 segmented.

CZausocalanus. of \& 0 Basal segments and exopodites of 2 nd. and $3 \mathrm{rd}$. legs do not show the above differences with the 4 th. legs $\ldots \ldots . \ldots 24$

24. 1st. and 2nd. marginal setae of $3 \mathrm{rd}$. and 4 th. legs comb-like. Ctenocalanus. of \&

1st. and 2nd. marginal setae of 3 rd. and 4 th. legs norma1......... 25

25. 5th legs present asymmetrical.

5 th legs absent

$\ldots \ldots \ldots+26$

$\ldots \ldots \ldots 27$

26. Endopodite of 1st. leg with 2 external spines; right 5 th 1 eg absent.

Endopodite of 1st. leg with 3 external spines; rostrum absent. Aetideus.

Chiridius.

27. Head without spine; exopodite of $3 \mathrm{rd}$. segment of $3 \mathrm{rd}$. and 4 th. legs with 4 inner setae; inner margin of basipodite segment 1 of 4 th. 1 eg naked or setose; posterior corner of metasome rounded; genital segment more or less asymmetrical with a lateral or ventral spine. Undeuchaeta. $q$ Head without spine; exopodite of segment 3 of $3 \mathrm{rd}$ and 4 th. 1 eg with 4 inner setae; inner margin of basipodite segment 1 of 4 th. 1 eg naked or setose; posterior corner of metasome terminated by a sharp point.

$\ldots \ldots \ldots 28$

28. Rostrum absent; exopodite of 2 nd. antenna longer than endopod; exopodite of 1 st. 


\section{Nyan Taw}

leg with 3 external spines; 2nd. maxilla without worm-like appendages.

Chiridius.

Rostrum thick, the two points separated down at the base; exopodite of $1 \mathrm{st}^{+}$leg with 2 external spines.

29. Head without medium dorsal spine; 5th. leg absent. Aetideus.

Head without medium dorsal spine; 5 th.

30. Posterior corner of metasome extended to a strong point; 1st. basipodite of 4 th. leg without spines or spinules; rostrum absent. Chiriaius. Posterior corner of metasome rounded or bluntly pointed. ........ ${ }_{3}^{0}$

31. 1st. basipodite of $4 \mathrm{th}$. leg with one or many spines or spinules on the internal margin; endopodite of 2nd. antenna at the most half the length of exopodite; exopodite of 1 st. 1 eg 2 segmented. Euchirella o $1 \mathrm{st}$. basipodite of $4 \mathrm{th}$. leg without spines or spinules; both branches of $2 \mathrm{nd}$. antenna nearly equal; maxilliped smaller, about as long as the head; two of the furcal setae always naked and usually much longer than others.

Euchaeta.

2. 5th. leg present on only one side, without endopodite or with very smal1 exopodite.

5 th leg with endopodite we11 developed. Aetideus.

33. Exopodite of left $5 \mathrm{th}$. leg terminated by one very 1 ong, very thin segment, often stylet-shaped; exopodite of right 5 th $1 \mathrm{eg}$ end in short pincers; right endopodite always rudimentary, 1st. antenna with very long isolated setae.

These features absent. Euchaeta. ........

34. Exopodite of left 5th. leg ends in a short pointed segment with a tuft of hairs on the inside; left endopodite less than half the length of right endopodite, basal segment very swollen. Undeuchaeta.

Exopodite of left 5 th. leg rarely pointed; either without hairs, or when hairs present never arranged in tufts; exopodite of 1st. leg with 2 segments; endopodite of 2nd. antenna at most half the length of exopodite. Euchirezza.

35. Head with a pair of dorsal lenses; endopodite of 1st. 1egs with 2 segments; 5 th. legs biramous in female, rami 1 segmented; in male right 5th. leg uniramous with chela. Labidocera.

No dorsal lenses; 5th. legs uniramous in both sexes. ....... 36

36. Maxilliped 3-4 segmented; exopodite of 2 nd. antennae shorter than the distal segment of endopodite; 2nd. maxilla with long spiny bristles on proximal and distal parts. Maxilliped 7 segmented.

Acartia. ơ \& .......... 37

37. Furca at least six times as long as wide; maxilliped twice as long as 2 nd. $\operatorname{maxilla.}$ Temora.

Furca at the most four times as long as wide; maxilliped shorter than 2nd. maxilla; 2nd. maxilla with short bristles on the proximal part and long scythelike bristles on the distal part; proximal basal segment of maxilliped with few short bristles. Candacia.

\section{Order CALANOIDA}

\section{Family CALANIDAE}

\section{Catonus australis Brodsky, 1959}

$$
\text { (figs } 2 a-d \text { ) }
$$

Previous Tasmanian Records: South of Tasmania (44 $05^{\prime} \mathrm{S}, 147^{\circ} 35^{\prime} \mathrm{E}$ ) (Vervoort, 1957); Mouth of River Derwent, D'Entrecasteaux Channel (Ong 1967, 1970; Ong and Lake 1970) as Calanus he Zgolandicus.

Occurrence: Inshore Coastal, Coastal and Oceanic. 
Notes

The species encountered in the present study agrees with Brodsky's (1959, 1961) description of Calanus austratis. This species was recorded by Ong $(1967,1970)$, Ong and Lake (1970) as C. helgolandicus. However, examination of the photographs (plate 19, lateral view of adult female and plate 20, serrated margin of the first basipodite of female 5th. legs) of Ong (1967) reveals that the number of teeth on the first basipodite of female 5th. legs was less than 17 on either side and the teeth were pointed and triangular.

Figure Explanations:

(a) male whole animal, lateral view,

(b) female whole animal, lateral view,

(c) male fifth leg, posterior aspect,

(d) female fifth leg, posterior aspect.

$$
\begin{gathered}
\text { Calanus minor (Claus, 1863) } \\
\text { (figs } 3 a-d)
\end{gathered}
$$

Previous Tasmanian Records: Ni1.

Occurrence: Inshore Coastal, Coastal and Oceanic.

Figure Explanations:

(a) male whole animal dorsal view,

(b) male fifth leg, posterior aspect,

(c) female last metasomal segment and urosome lateral view,

(d) female fifth leg, posterior aspect.

$$
\begin{gathered}
\text { Calanoides carinatus (Kroyer, 1849) } \\
\text { (figs 4a - c) }
\end{gathered}
$$

Previous Tasmanian Records: South of Tasmania ( $44^{\circ} 05^{\prime} \mathrm{S}, 147^{\circ} 35^{\prime} \mathrm{E}$ ) (Vervoort, 1957).

Occurrence: Inshore Coastal, Coastal and Oceanic.

Figure Explanations:

(a) female whole anima1, dorsal view,

(b) female fifth $1 \mathrm{eg}$, posterior aspect,

(c) female whole animal, lateral view.

\section{Mesocalanus tenuicomis (Dana, 1848)} (figs $5 \mathrm{a}-\mathrm{d}$ )

Previous Tasmanian Records: Ni1.

Occurrence: Inshore Coasta1, Coastal and Oceanic.

Figure Explanations:
(a) female whole animal, lateral view,
(b) male fifth leg, posterior aspect,
(c) female fifth 1 eg, posterior aspect,
(d) female urosome, ventral view.

$$
\text { Neocalanus robustion (Giesbrecht, 1891) }
$$

Previous Tasmanian Records: Nil.

$$
\text { (figs } 6 \mathrm{a}-\mathrm{e})
$$

Occurrence: Coastal and Oceanic.

Figure Explanations:
(a) female whole animal, dorsal view,
(b) female first leg, anterior aspect,
(c) female last metasomal segment and urosome, lateral view,
(d) female second leg showing first endopodite and first exopodite, posterior aspect,
(e) female second maxilla, lateral view.

$$
\begin{gathered}
\text { Neocalanus tonsus (Brady, 1883) } \\
\text { (figs 7a - d) }
\end{gathered}
$$


Nyan Taw
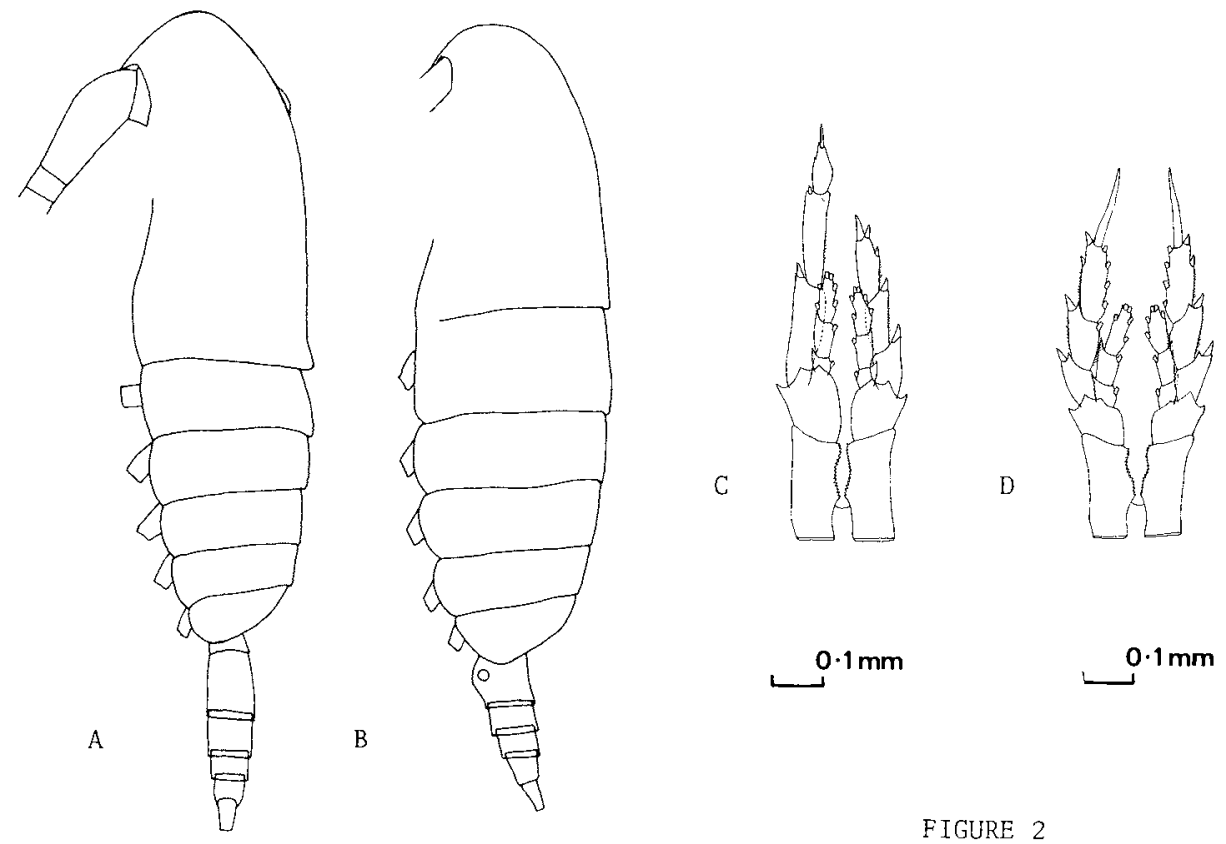

FIGURE 2
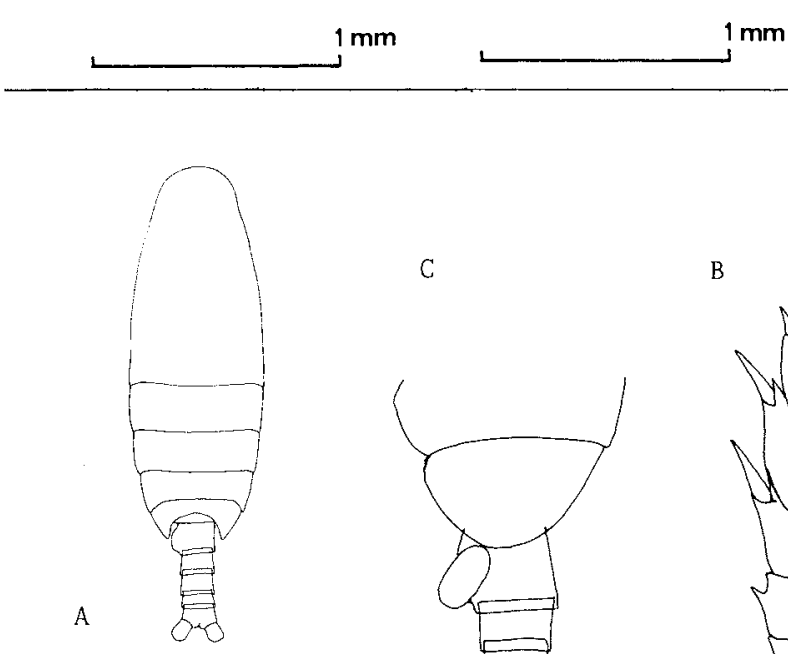

$1 \mathrm{~mm}$

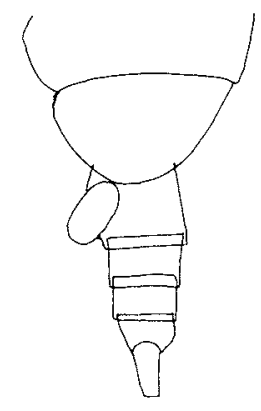

B

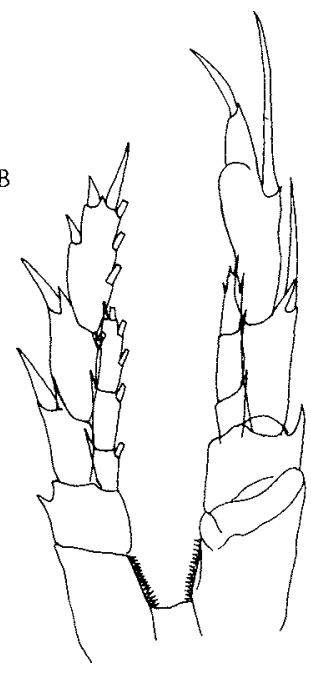

D

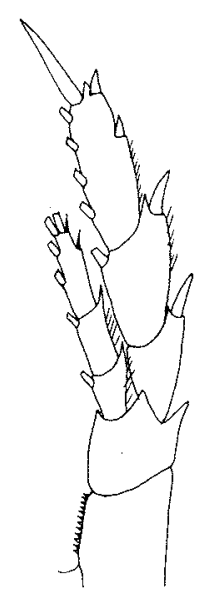

$0.1 \mathrm{~mm}$
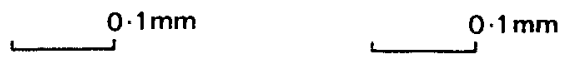

FIGURE 3 

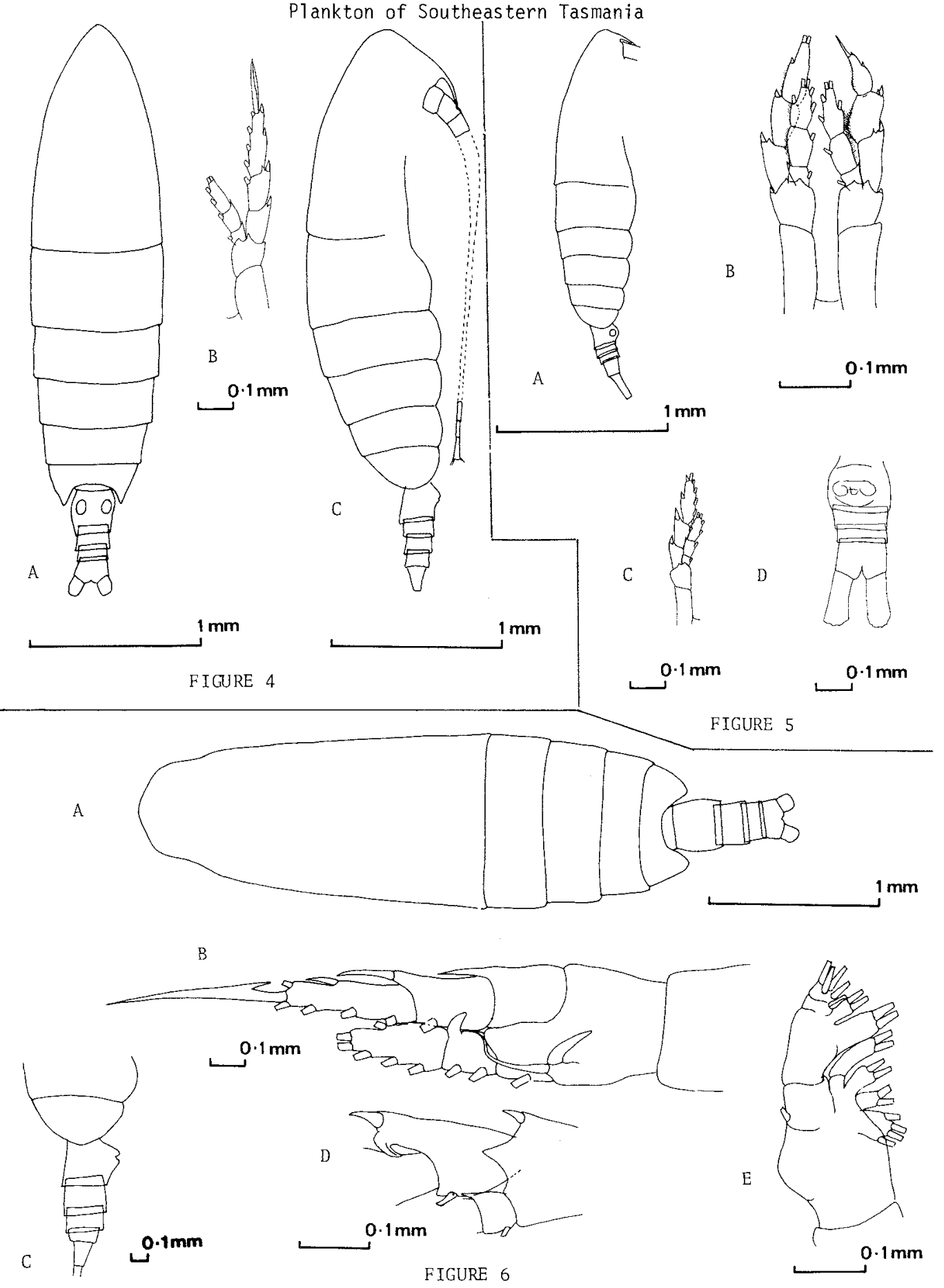


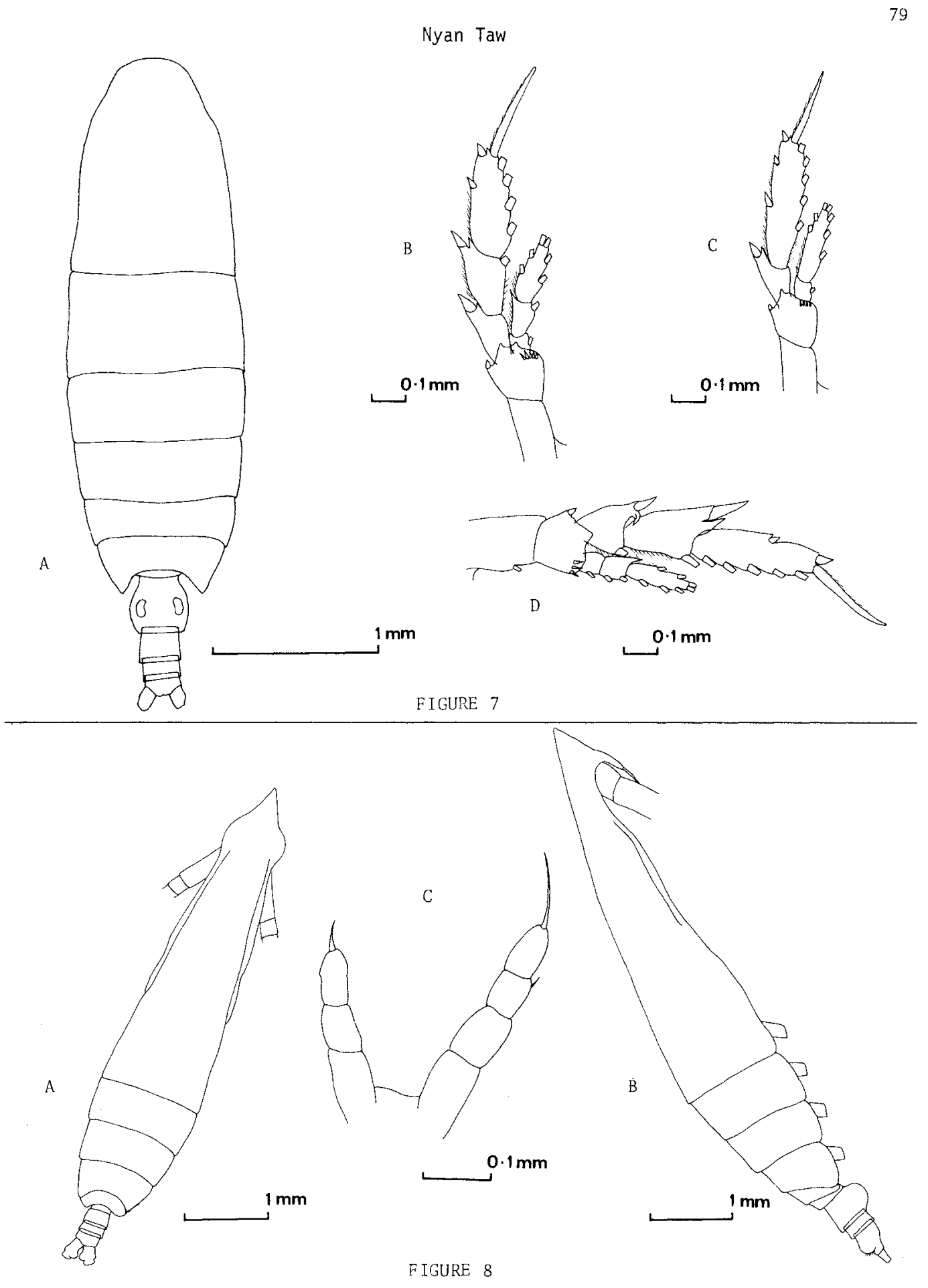




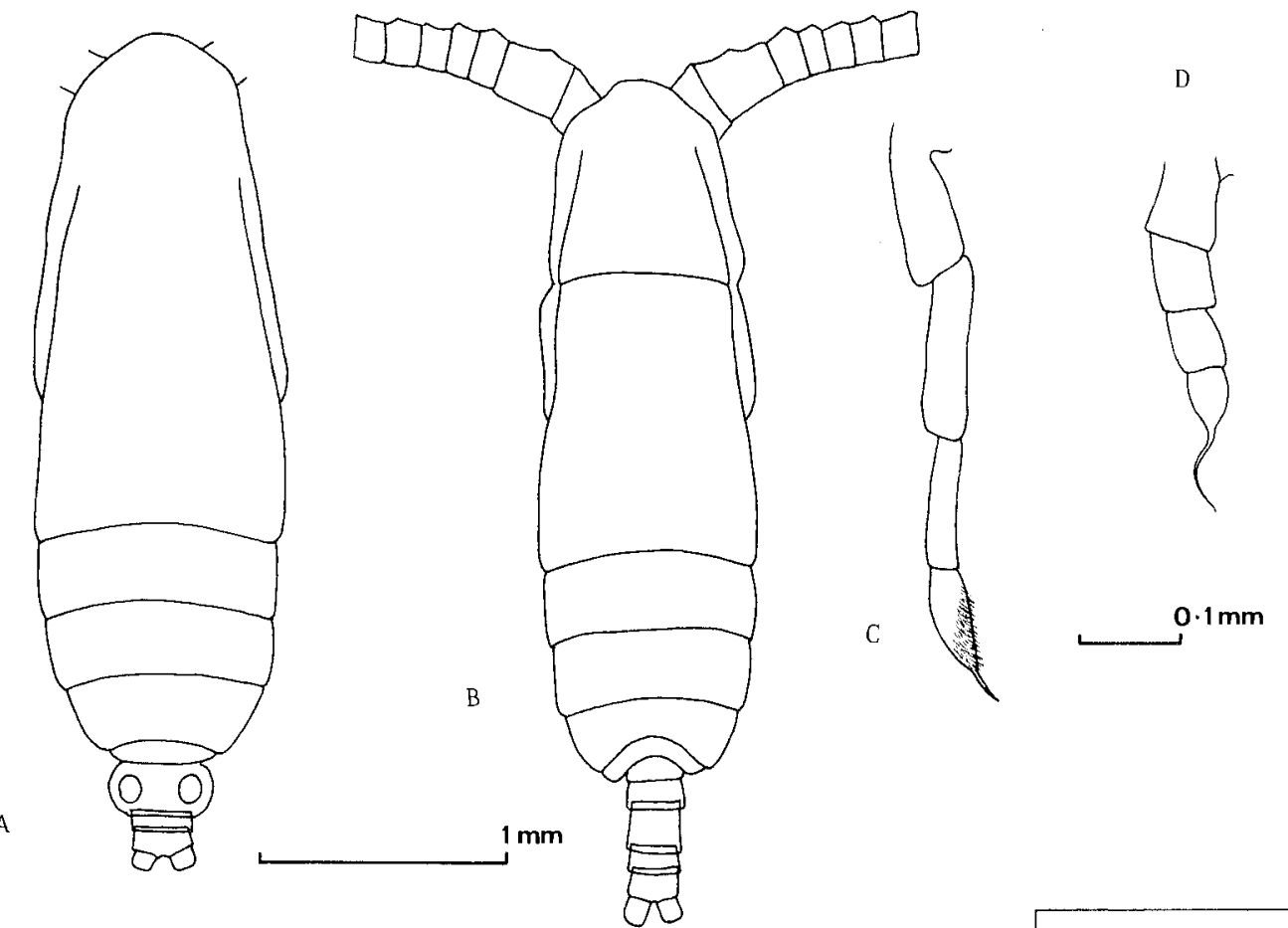

F IGURE 9
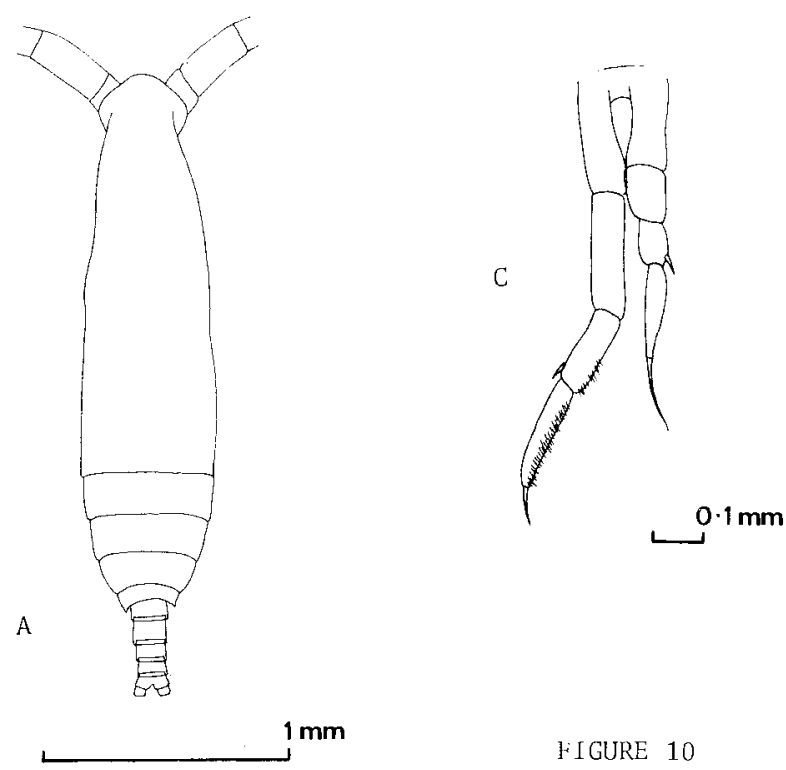

B

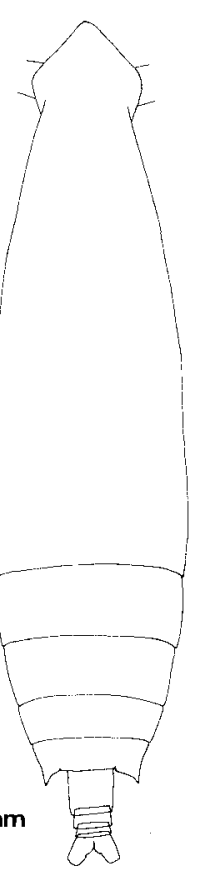

kIGURE 10

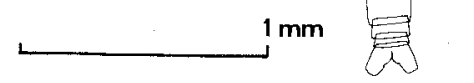


Reference Specimen: Tranter, C.S.I.R.0., Cronu11a, Bott1e No. 18, Sample No. South Coast N.S.W.

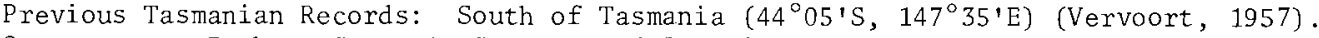
Occurrence: Inshore Coasta1, Coastal and Oceanic.

Figure Explanations:

(a) female whole animal, dorsal view,

(b) female fifth leg, posterior aspect,

(c) female fifth leg of fifth copepodite stage, posterior aspect.

(d) female second $1 \mathrm{eg}$, posterior aspect.

\section{Family EUCALANIDAE \\ Genus Eucazonus}

Key to the Species

Female - Urosome with $3-4$ segments, the last of which is fused with the furca; genital aperture on the ventral surface, which is longer and broader than the following segment; fifth legs absent.

Ma1e - Urosome with five segments; genital aperture on the left side of the first segment; fifth legs asymmetrical. Key to the Females of the Species

1. Urosome 4 segmented. Urosome 3 segmented.

E. elongatus .......... 2

2. Forehead flatly rounded, genital segment onion shaped, much broader than long; tooth lacking on outer margin of second endopodite of second to fourth legs.

Forehead triangular, metasome elongated.

E. crassus $\ldots \ldots+\ldots, \ldots$

3. Forehead triangular and very elongate; furcal rami broader than long. E. Zongiceps

Forehead triangular and elongate; furcal rami as 1 ong as broad or longer.

$$
\text { Key to the Males of the Species }
$$

1. Both fifth legs present

E. attenuatus

Only left fifth leg present

$\begin{array}{lllll}\cdots & \cdots & \ldots & \ldots & 2\end{array}$

$\ldots \ldots \ldots$

2. Forehead triangular, bluntly rounded anteriorly; posterior corner of the last metasomal segment pointed.

E. eZongatus

3. Forehead triangular, very elongated and pointed anteriorly metasome elongate.

Forehead flatly rounded, metasome not elongate.
E. Zongiceps
E. crassus

Eucalanus attenuatus (Dana, 1848)

(figs $8 a-c)$

Previous Tasmanian Records: Nil.

Occurrence: Coastal and Oceanic.

Figure Explanations:

(a) immature male whole animal, dorsal view,

(b) female whole animal, 1ateral view,

(c) immature male fifth leg.

\section{EucaZomus crassus (Giesbrecht, 1902)}

Previous Tasmanian Records: Nil.

$$
\text { (figs } 9 a-d)
$$

Occurrence: Coasta1 and Oceanic.

Figure Explanations:

(a) female whole animal, dorsal view,

(b) male whole animal, dorsal view,

(c) male fifth leg,

(d) immature male fifth leg. 
Previous Tasmanian Records: South of Tasmania (44 ${ }^{\circ} 05^{\prime} \mathrm{S}, 147^{\circ} 35^{\prime} \mathrm{E}$ ) (Vervoort, 1957). Occurrence: Coastal and Oceanic.

Figure Explanations:

(a) male whole animal, dorsal view,

(b) female whole animal, dorsal view,

(c) male fifth leg.

Eucalanus Zongiceps Matthews, 1925

$$
\text { (figs } 11 \mathrm{a}-\mathrm{d} \text { ) }
$$

Previous Tasmanian Records: South of Tasmania (44 $05^{\prime}$ S, $\left.147^{\circ} 35^{\prime} \mathrm{E}\right)$ (Vervoort, 1957). Occurrence: Coastal and Oceanic.

Figure Explanations:

(a) male whole animal, lateral view,

(b) female whole animal, dorsal view,

(c) male head, lateral view,

(d) male fifth leg.

Mecynocera clausi Thompson, 1888

$$
\text { (figs } 12 \mathrm{a} \& \mathrm{~b} \text { ) }
$$

Previous Tasmanian Records: South of Tasmania (44 $05^{\prime} \mathrm{S}, 147^{\circ} 35^{\prime} \mathrm{E}$ ) (Vervoort, 1957). Figure Explanations:

(a) female whole animal, lateral view,

(b) female fifth leg.

\section{Rhincalanus nasutus (Geisbrecht, 1888)}

$$
\text { (figs } 13 a-c)
$$

Previous Tasmanian Records: South of Tasmania ( $44^{\circ} 05^{\prime} \mathrm{S}, 147^{\circ} 35^{\prime} \mathrm{E}$ ) (Vervoort, 1957). Occurrence: Coastal and Oceanic.

Figure Explanations:

(a) female whole animal, dorsal view,

(b) male fifth leg,

(c) female fifth leg.

Family PARACALANIDAE

Genus Calocalanus

Key to the Females of the Species

1. Urosome 2 segmented; body stout; genital segment onion shaped, broader than 1ong; female fifth leg 4 segmented with four or five apical setae; furcal rami two times as long as wide and widely divergent; length $0.88-1.2 \mathrm{~mm}$.

$$
\text { C. pavo }
$$

Urosome 3 segmented; body stout or slender; genital segment onion shaped or normal; furcal rami as long as wide. $\ldots . . . . \ldots 2$

2. Metasome slender and fusiform; genital segment longer than broad; fifth legs four segmented with three apical setae; furcal rami parallel. C. tenuis Metasome stout or little slender; genital segment onion shaped; fifth legs three segmented; furcal rami slightly divergent.

$\ldots \ldots \ldots 3$

3. Metasome stout; genital segment partly covering the second segment; fifth legs with one terminal setae.

Metasome little slender, fifth legs with two terminal setae.

$$
\text { C. styziremis }
$$

C. contractus 


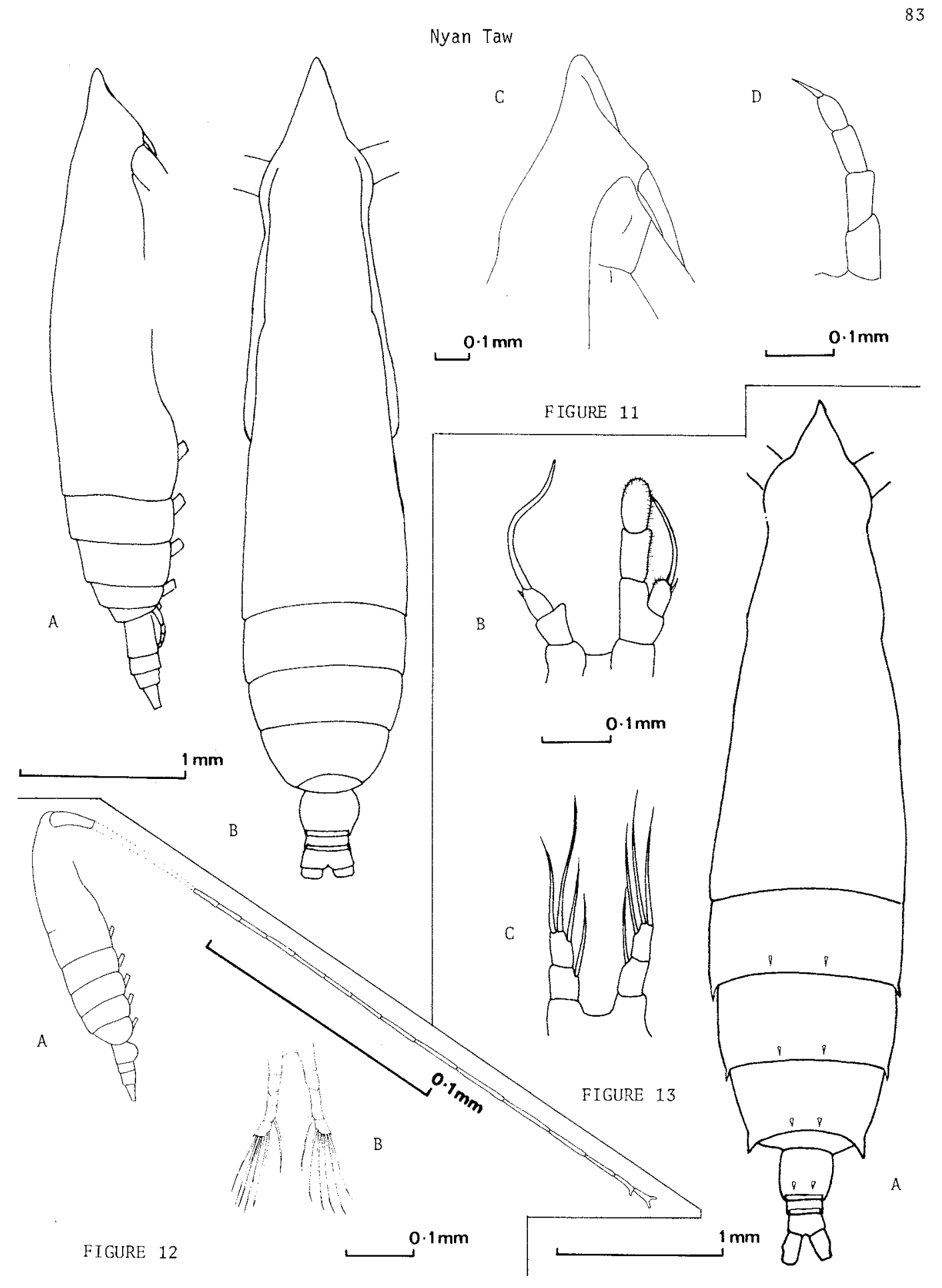




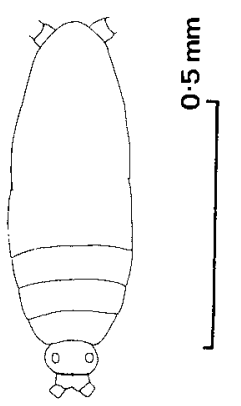

A

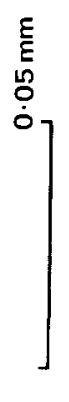

B

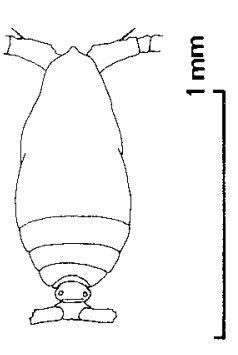

A

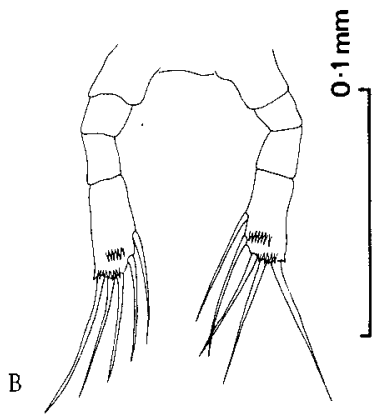

FIGURE 14

FIGURE 15

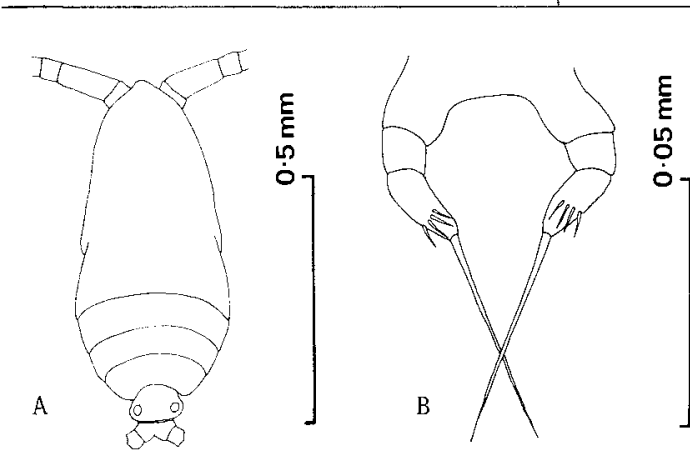

FIGURE 16

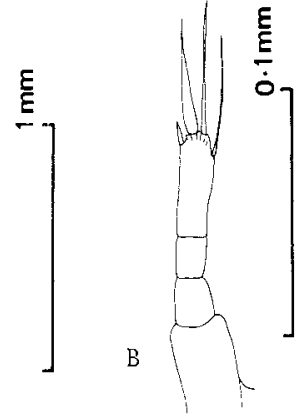

FIGURE 17

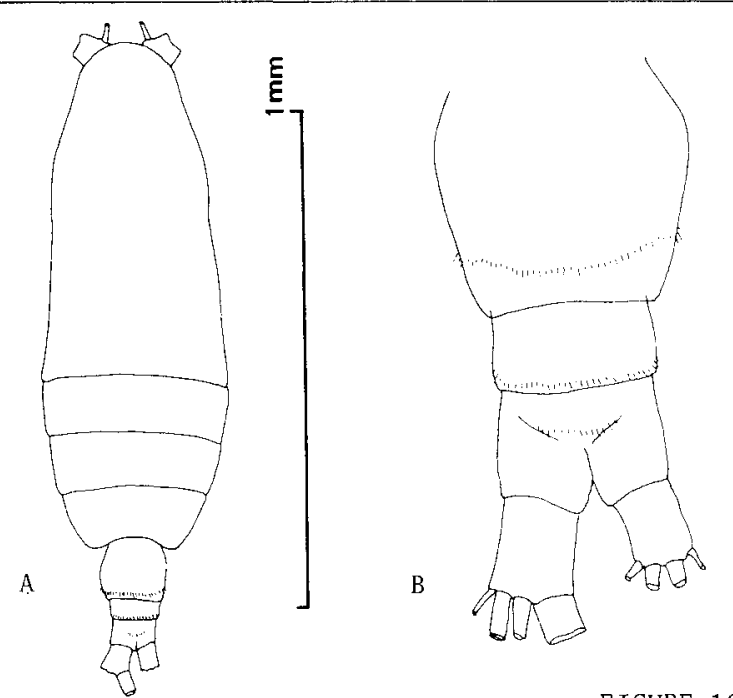

FIGURE 18

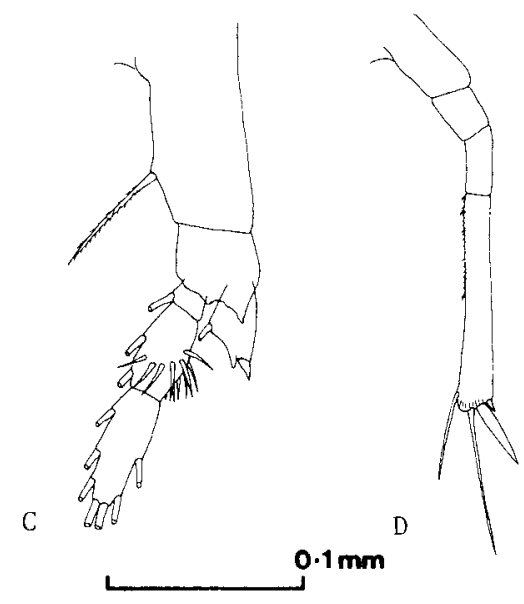




\section{Nyan Taw}

Calocalanus contractus (Farran, 1936)

Previous Tasmanian Records: Nil. (Figs 14a \& b)

Figure Explanations:

(a) female whole animal, dorsal view,

(b) female fifth leg.

Calocalonus pavo (Dana, 1848)

(figs $15 \mathrm{a} \& \mathrm{~b}$ )

Previous Tasmanian Records: Nil.

Occurrence: Inshore Coastal, Coastal and Oceanic.

Figure Explanations:

(a) female whole animal, dorsal view,

(b) female fifth leg.

CalocaZanus styZiremis (Giesbrecht, 1888)

Previous Tasmanian Records: Nil.

(figs 16 a \& b)

Occurrence: Inshore Coasta1, Coastal and Oceanic.

Figure Explanations:

(a) female whole animal, dorsal view,

(b) female fifth $1 \mathrm{eg}$.

Catocatonus tenuis (Farran, 1926)

(figs $17 a \& b$ )

Previous Tasmanian Records: Nil.

Occurrence: Inshore Coastal, Coastal and Oceanic.

Figure Explanations:

(a) female whole animal, dorsal view,

(b) female fifth leg.

Previous Tasmanian Records: Nil.

Leptocalanus plumulosus (C1aus, 1863)

(figs $18 \mathrm{a}-\mathrm{d}$ )

Occurrence: Inshore Coastal, Coastal and Oceanic.

Figure Explanations:

(a) female whole animal, dorsal view,

(b) female urosome, dorsa1 view,

(c) third leg (without distal expodite segment),

(d) female fifth leg.

Paracalanus parvus (C1aus, 1863)

(figs $19 a-g$ )

Previous Tasmanian Records: South of Tasmania ( $44^{\circ} 05^{\prime} \mathrm{S}, 147^{\circ} 35^{\prime} \mathrm{E}$ ) (Vervoort, 1957 ).

Occurrence: Estuarine, Inshore Coastal, Coastal and Oceanic.

Figure Explanations:

(a) male whole animal, lateral view,

(b) male fourth leg, posterior aspect,

(c) male fifth leg,

(d) female second leg, posterior aspect,

(e) female whole animal, lateral view,

(f) female mandible,

(g) female fifth leg. 
Key to adult females of the Species

1. In lateral view ventral profile of genital segment conspicuously protruberant anterior to genital pores; rostrum short, slender and curved in lateral view.

$$
\text { C. jobei }
$$

In lateral view ventral profile of genital segment not conspicuously protruberant anterior to genital pore.

$$
\ldots \ldots \ldots 2
$$

2. Third segment of fifth legs less than 2.0 times as long as first segment of the same leg $\ldots \ldots \ldots 3$ Third segment of fifth legs more than 2.0 times as long; as first segment of the same leg.

$$
\ldots \ldots \ldots 5
$$

3. Forehead usually strongly vaulted spiniform of the second basipodite of the third leg narrow and uniformly taped from the base. C. laticeps Forehead not vaulted; spiniform processes of the second basipodite of the third leg thick and not uniformly tapered from base $\ldots . . . .4$

4. In lateral view rostrum slender and curved, in lateral view forehead broady rounded, protruberant above rostrum; in lateral view the dorsal lobe of seminal receptacle large and originates from the anterior part of the ventral lobe and is directed dorsoanteriorly.

C. ingens

In lateral view rostrum thick and usually curved ventroposteriorly; in lateral view forehead broadly rounded but not markedly protruberant above rostrum; in lateral view dorsal often inconspicuous, 1 ong and slender, usually directed dorsally or dorso-anteriorly. C. mastigophorus

5. In lateral view dorsal lobe of seminal receptical arising from anterior edge of ventral lobe (fig. 20d); dorsal lobe not bulb shaped; the spiniform processes thick and not uniformly tapered from base.

C. arcuicornis

In lateral view dorsal lobe of seminal receptical bulb shaped, constricted in the region of attachment to ventral lobe; furcal ramus more than 1.52 times as long as wide first antennae segment 2 more than 1.40 times as 1 ong as segment 24. C. Brevipes

In lateral view dorsal lobe of seminal receptical bulb shaped, constricted in the region of attachment to ventral lobe; furcal ramus less than 1.52 times as long as wide first antennae segment 2 less than 1.40 times as 1 ong as segment 24.

C. parapergens

\section{Clausocatanus areuicomis (Dana, 1849)}

$$
\text { (figs } 20 a-e)
$$

Previous Tasmanian Records: Nil.

Occurrence: Inshore coastal (The occurrence in the Coastal and Oceanic waters was not determined due to the difficulties involved in identification).

Figure Explanations:

(a) female whole animal, lateral view,

(b) female rostrum,

(c) female second basipodite of third leg, posterior aspect,

(d) female last metasomal segment and genital segment, lateral view,

(e) female fifth leg.

Clausocatanus brevipes Frost and Fleminger, 1968

$$
\text { (figs 21a - e) }
$$

Reference Specimen: Frost, C.S.I.R.0., Cronul1a, Bottle No. 39, Sample No. Thala Dan $5 \mathrm{H}$.

Previous Tasmanian Records: Nil.

Occurrence: A few specimens ( 6 in number) identified were taken from only one station 
Nyan Taw

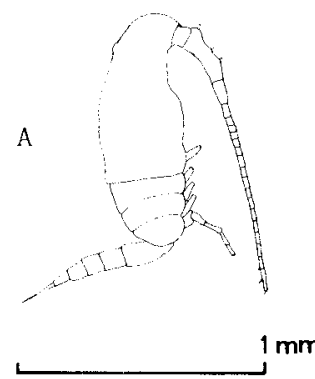

B.

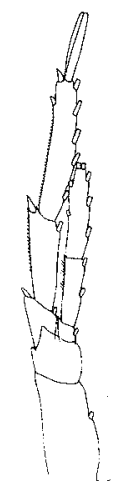

$0.1 \mathrm{~mm}$

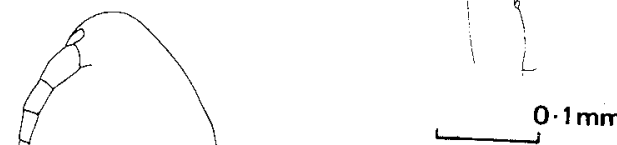

E

$1 \mathrm{~mm}$

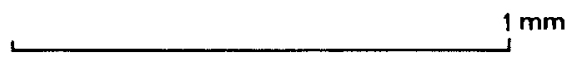

FIGURE 19

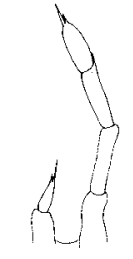

$0.1 \mathrm{~mm}$
D
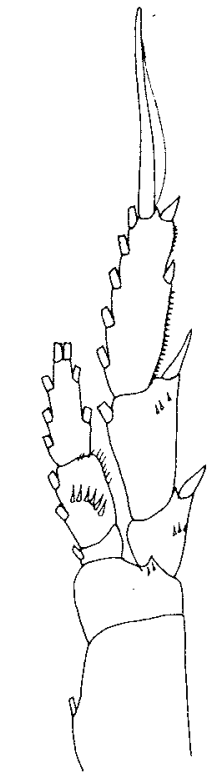

$0.1 \mathrm{~mm}$

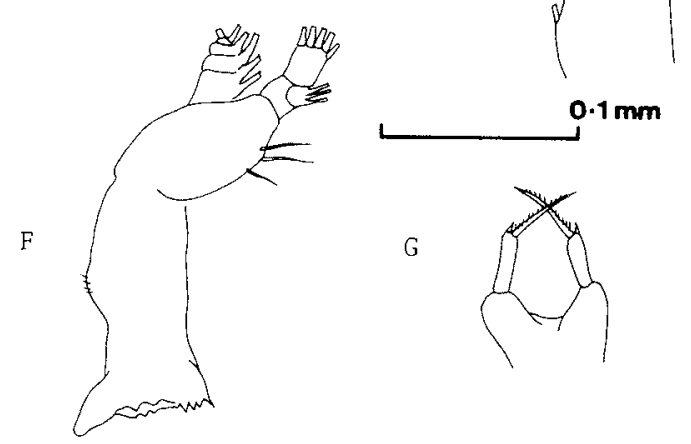

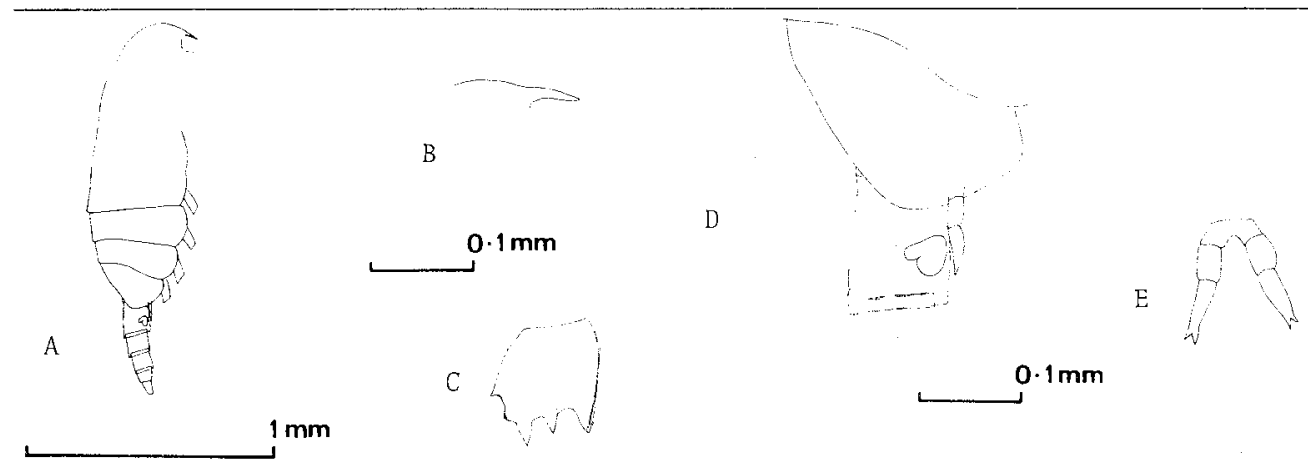

FIGURE 20 
Plankton of Southeastern Tasmania
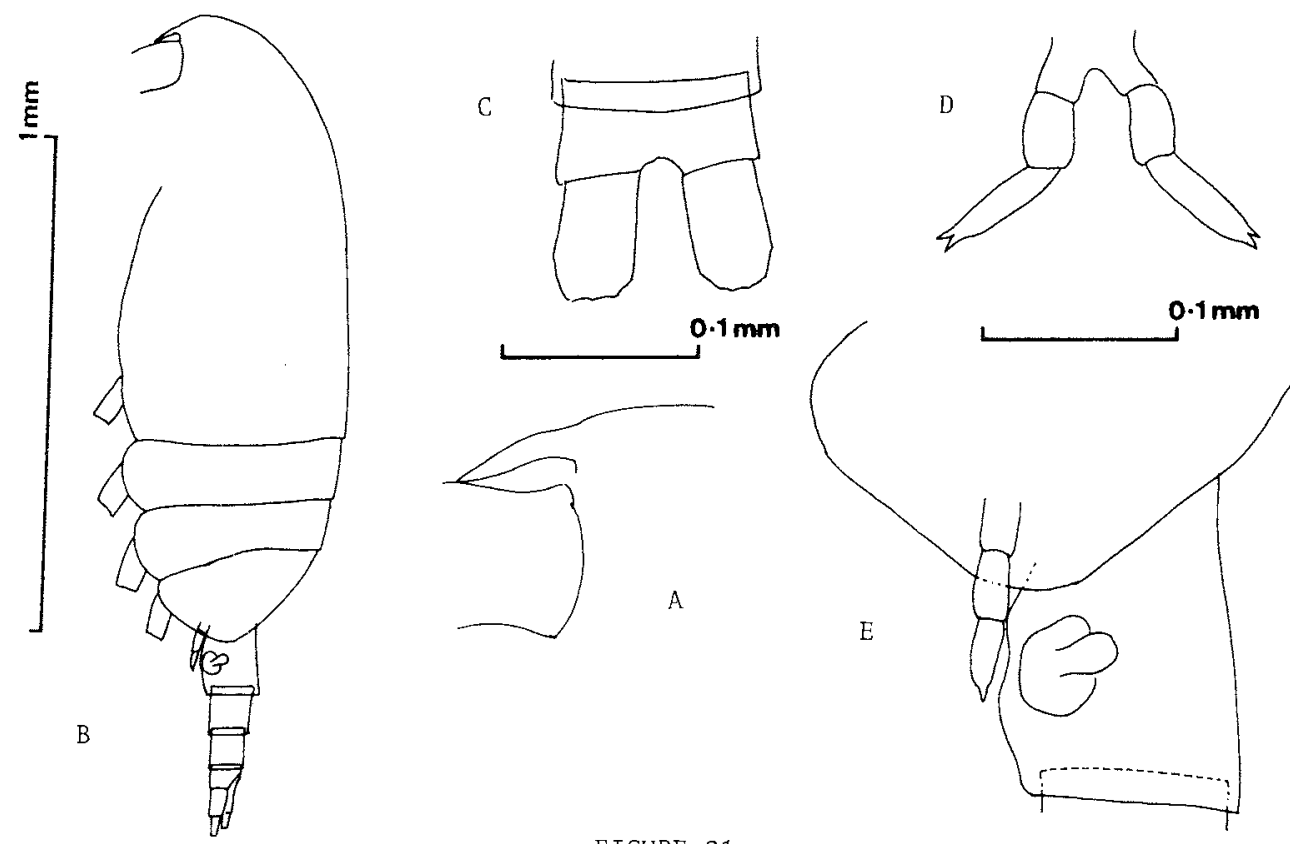

FIGURE 21
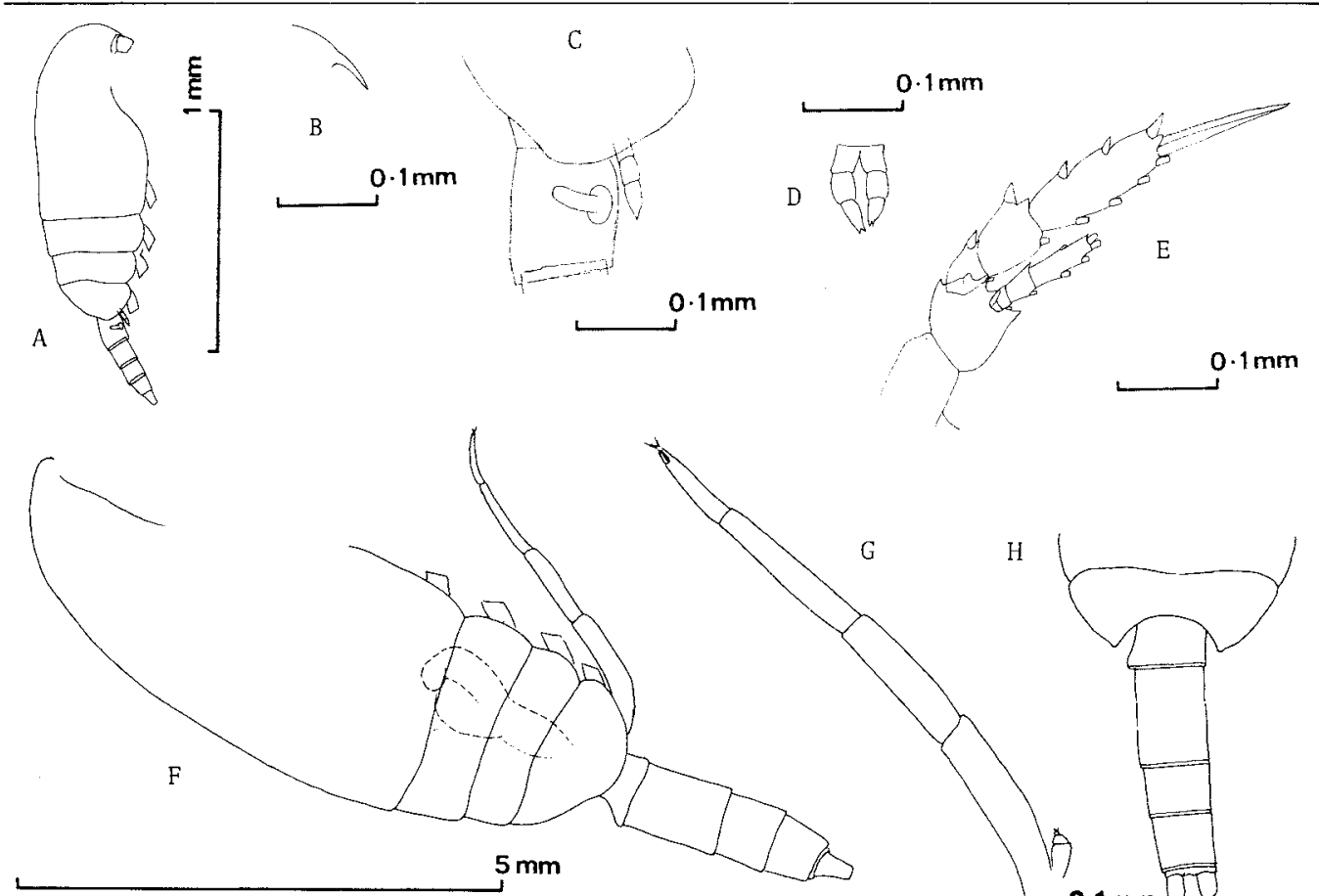

FIGURE 22

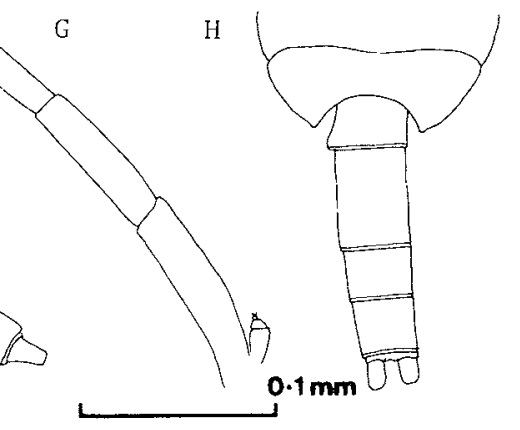




\section{Nyan Taw}

(St. E2, Nov. 1972). (The occurrence in the Coastal and Oceanic waters was not determined due to the difficulties involved in identification).

Figure Explanations:

(a) female rostrum, lateral view,

(b) female whole animal, lateral view,

(c) female furcal rami, dorsal view,

(d) female fifth leg,

(e) female last metasomal segment and genital segment, lateral view.

Clausocazanus ingens Frost and Fleminger, 1968

(figs $22 \mathrm{a}-\mathrm{h}$ )

Reference Specimens: Frost, C.S.I.R.o., Cronulla, Bottle No. 38, Sample No. Thala Dan $5 \mathrm{H}$.

Previous Tasmanian Records: Nil.

Occurrence: Inshore coastal, Coastal and Oceanic.

Figure Explanations:

(a) female whole anima1, lateral view,

(b) female rostrum, lateral view,

(c) female last metasomal segment and genital segment, lateral view,

(d) female fifth $1 \mathrm{eg}$,

(e) female third leg, posterior aspect,

(f) male whole animal, lateral view,

(g) male fifth $1 \mathrm{eg}$,

(h) ma1e last metasomal segment and urosome, dorsal view.

Clausocatanus jobei Frost and Fleminger, 1968

(figs $23 a-c)$

Reference Specimen: Frost, C.S.I.R.o., Cronulla, Bottle No. 39, Sample No. Patanela $2107 \mathrm{E}$.

Previous Tasmanian Records: Nil.

Occurrence: Inshore coastal. (The occurrence in the Coastal and Oceanic waters was not determined due to the difficulties involved in identification).

Figure Explanations:

(a) female whole animal, lateral view,

(b) female last metasomal segment and genital segment, lateral view,

(c) female fifth leg.

CZausocazanus Zaticeps Farran, 1929

(figs $24 a-e)$

Reference Specimen: Vervoort, C.S.I.R.0., Cronulla, Bottle No. 32, Sample No. Wm. Barondz A004.

Previous Tasmanian Records: South of Tasmania (44 $\left.05^{\prime} \mathrm{S}, 147^{\circ} 35^{\prime} \mathrm{E}\right)$ (Vervoort, 1957). Occurrence: Coastal and Oceanic.

Figure Explanations:

(a) female anterior of the head, lateral view,

(b) female whole animal (another specimen), lateral view,

(c) female second basipodite of third $1 \mathrm{eg}$, posterior aspect,

(d) female urosome, dorsal view,

(e) female fifth leg.

Clausocalanus mastigophoms (C1aus, 1863)

(figs $25 \mathrm{a}-\mathrm{d}$ )

Reference Specimen: Frost, C.S.I.R.O., Cronulla, Bottle No. 40, Sample No. 1133E. Previous Tasmanian Records: Ni1.

Occurrence: Inshore coastal. (The occurrence in the Coastal and Oceanic waters was not determined due to the difficulties involved in identification). 
90

\section{Plankton of Southeastern Tasmania}

Figure Explanations:

(a) female whole animal, lateral view,

(b) female second basipodite of third leg, posterior aspect,

(c) female last metasomal segment and genital segment, lateral view,

(d) female fifth $1 \mathrm{eg}$.

Clausocalanus parapergens Frost and F1eminger, 1968

$$
\text { (figs 26a - e) }
$$

Reference Specimen: Frost, C.S.I.R.O., Cronulla, Bottle No. 41, Sample No. 1178E. Previous Tasmanian Records: Nil.

Occurrence: Inshore coastal. (The occurrence in the Coastal and Oceanic waters was not determined due to the difficulties involved in identification).

Figure Explanations:

(a) female first antenna,

(b) female whole animal, lateral view,

(c) female furcal rami, dorsal view,

(d) female fifth leg,

(e) female seminal recepticle, lateral view.

Ctenocalanus vanus Giesbrecht, 1888

figs $27 a-e)$

Previous Tasmanian Records: Nil.

Occurrence: Inshore coasta1, Coastal and Oceanic.

Distribution: Off the French Coast (Rose 1933); Southeastern Australian waters (Dakin and Colefax 1933, 1940); off Kaikoura, New Zealand (Bradford 1970, 1972); Hauraki Gulf, New Zealand (Jillett 1971).

Figure Explanations:

(a) female whole animal, dorsal view,

(b) male whole animal, dorsal view,

(c) female fourth leg, posterior aspect,

(d) female lateral serrated spines of the third exopodite of the fourth leg,

(e) male fifth leg.

Family AETIDEIDAE

Aetideus pseudarmatus Bradford, 1971

Previous Tasmanian Records: Nil.

Occurrence: Station E9, November 1972 - 1 female.

Figure Explanations:

(a) female whole animal, lateral view,

(b) female last metasomal segment and genital segment, lateral view,

(c) female mandible,

(d) female fourth leg.

Chiridius gracizis Farran, 1908

$$
\text { (figs } 29 \mathrm{a}-\mathrm{d} \text { ) }
$$

Previous Tasmanian Records: South of Tasmania ( $44^{\circ} 05^{\prime} \mathrm{S}, 147^{\circ} 35^{\prime} \mathrm{E}$ ) (Vervoort 1957). Occurrence: Station E1, November, 1972 - 6 females.

Figure Explanations:
(a) female whole animal, dorsal view,
(b) female second leg,
(c) female fourth leg,
(d) mandible and palp. 
Nyan Taw
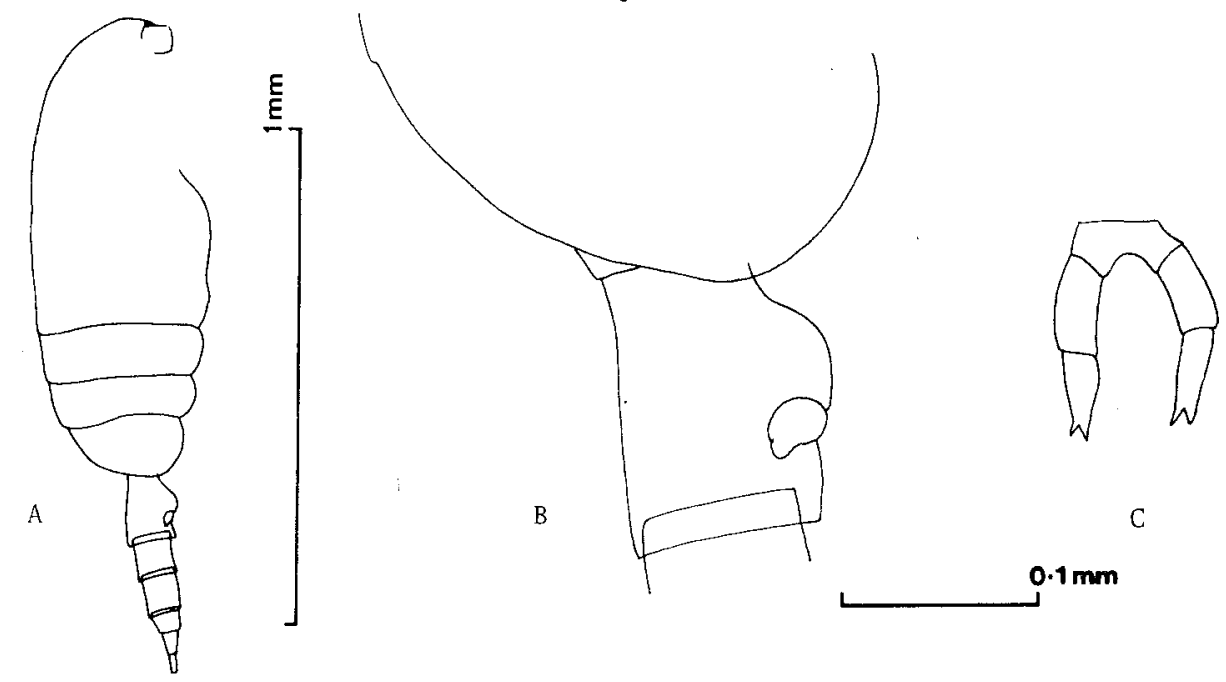

B

FIGURE 23

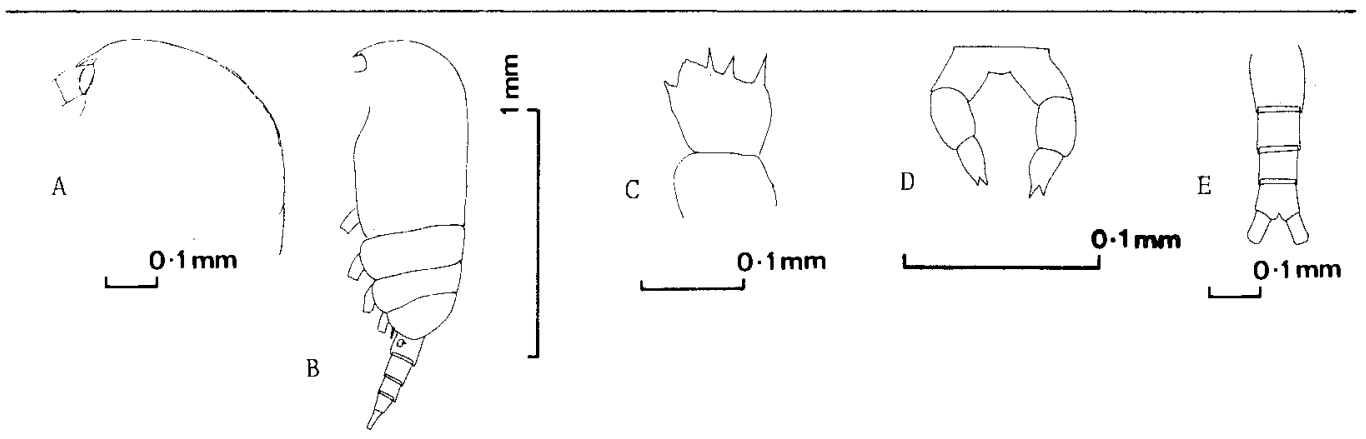

FIGURE 24
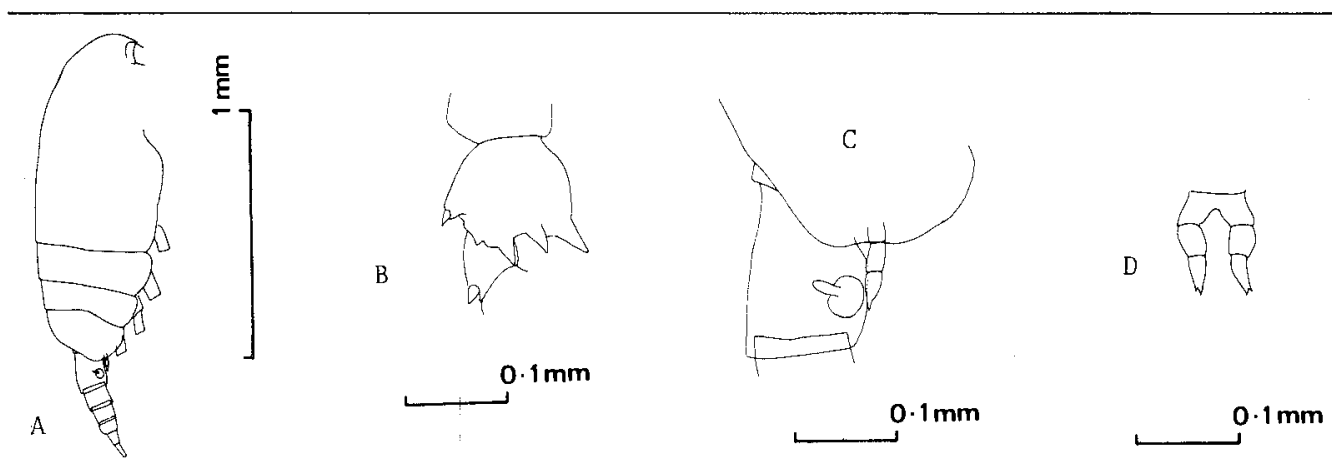

FIGURE 25 


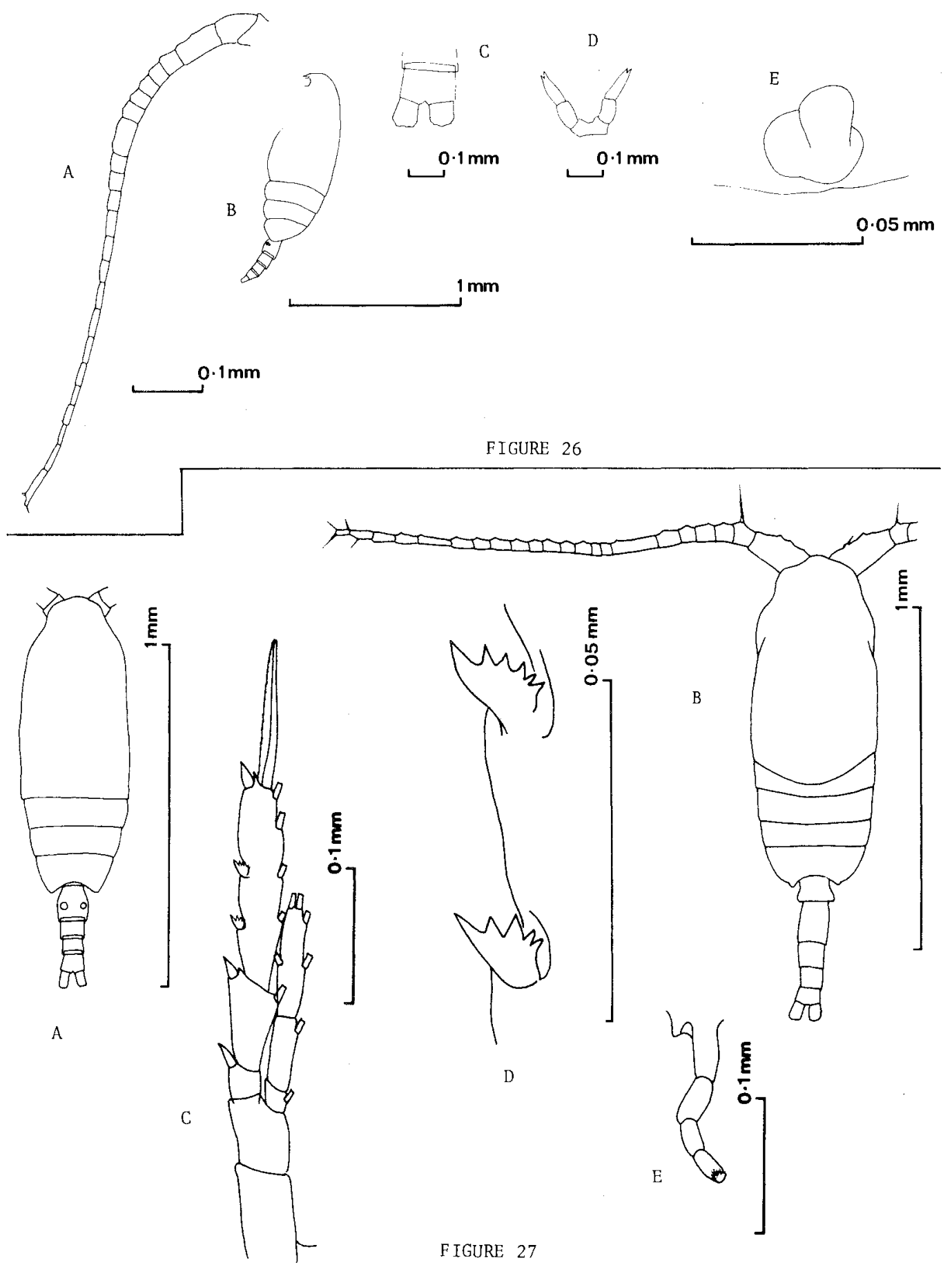


Nyan Taw
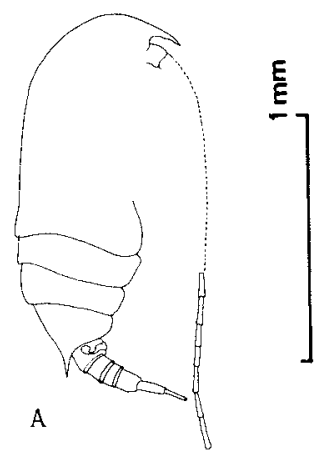

B
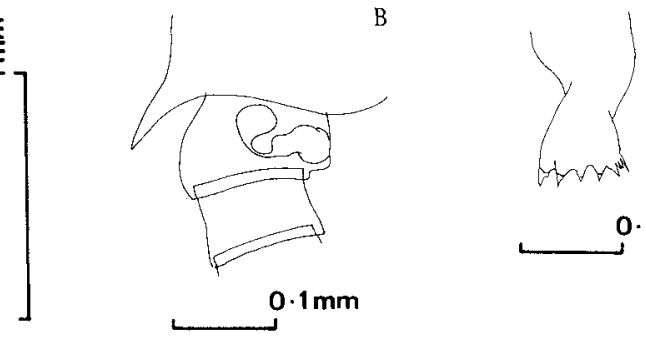

C

FIGURE 28

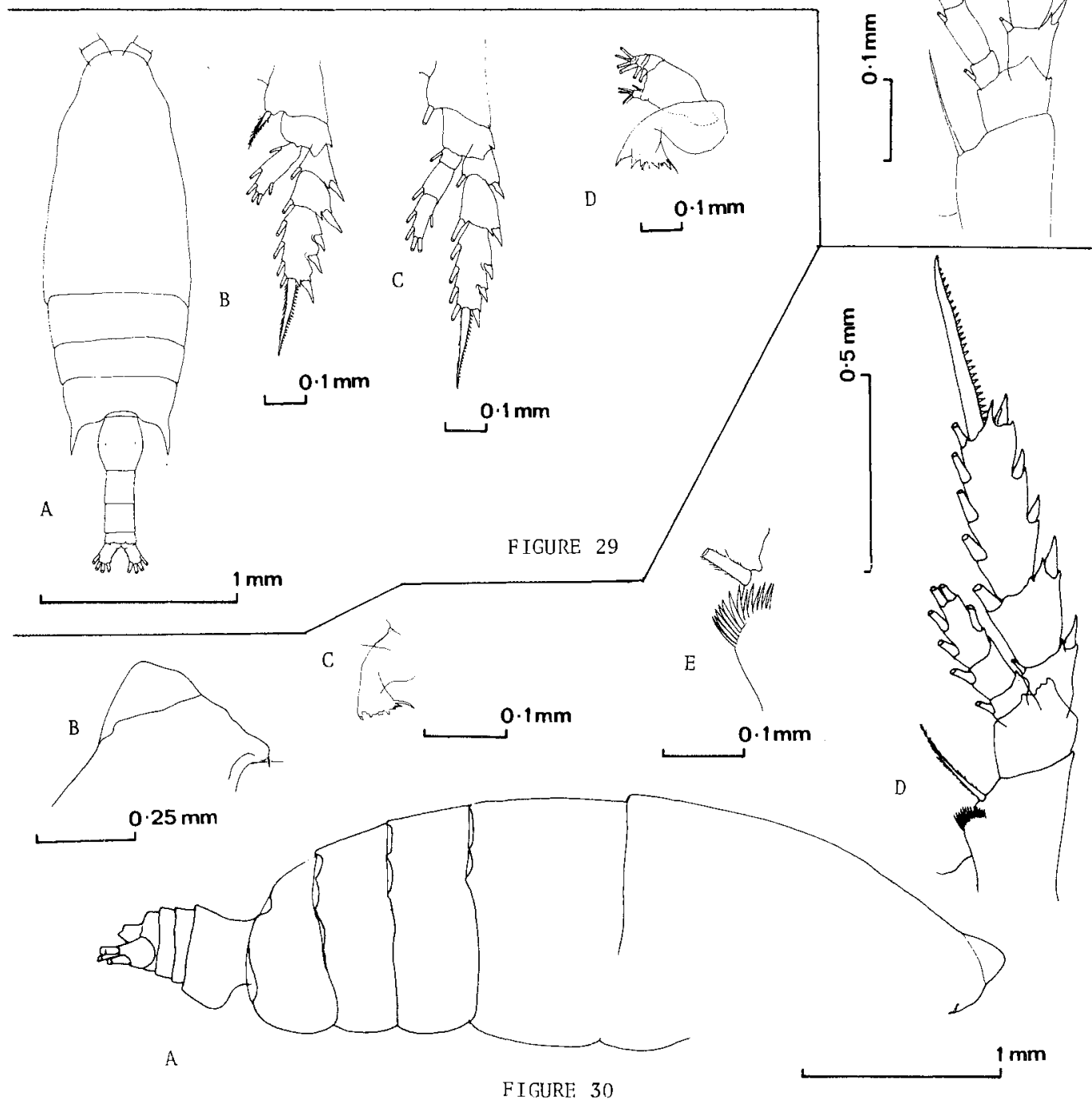


Plankton of Southeastern Tasmania
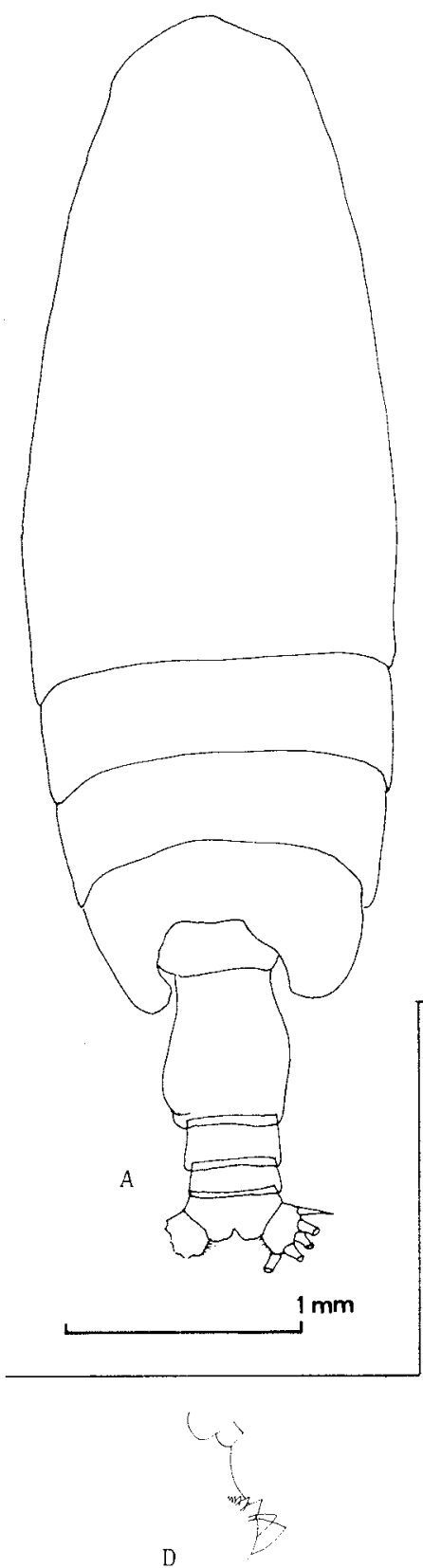

$0.1 \mathrm{~mm}$
B
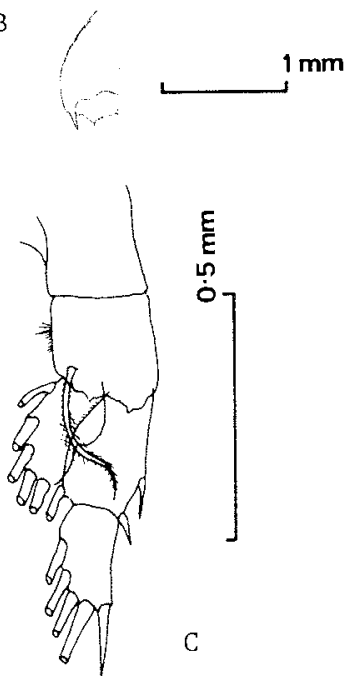

FIGURE 31

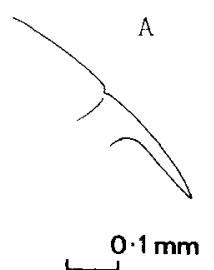

$0.1 \mathrm{~mm}$
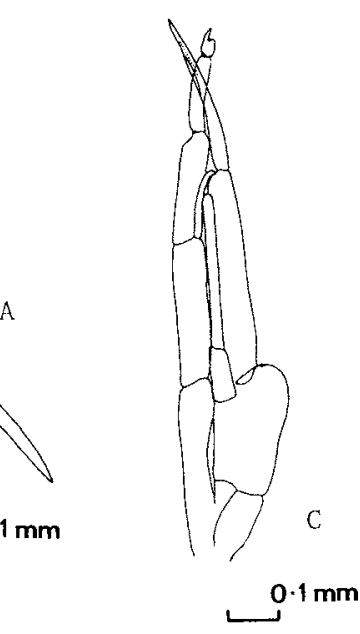
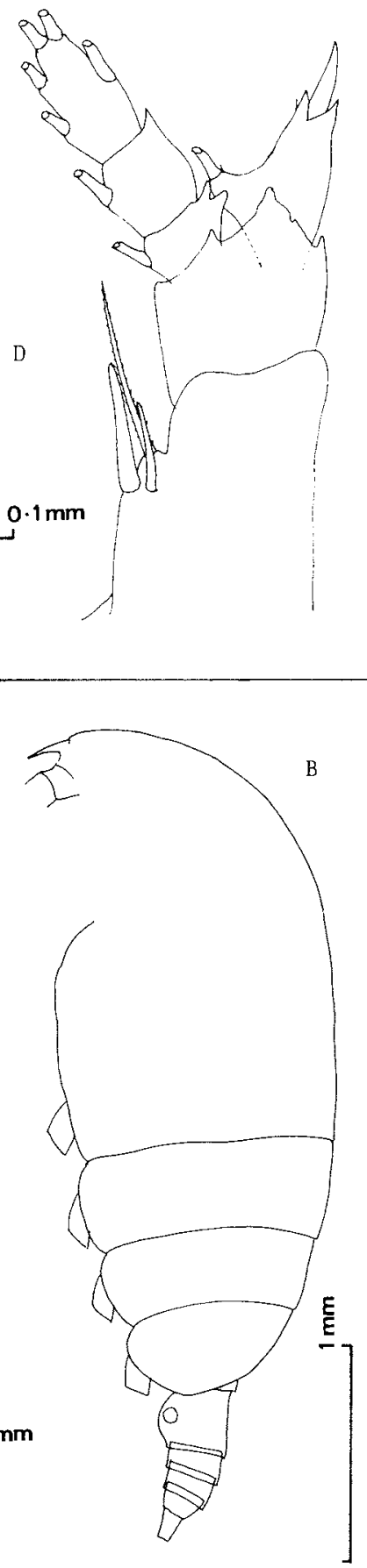

FIGURE 32 


\section{Nyan Taw}

Euchirella curticauda Giesbrecht, 1888

(figs $30 a-e)$

Previous Tasmanian Records: Nil.

Occurrence: Station E6, May, 1973 - 1 female.

Figure Explanations:

(a) female whole animal, lateral view,

(b) female anterior region of head, lateral view,

(c) female mandible,

(d) female fourth leg, posterior aspect,

(e) inner region of fj.rst basal segment of female fourth leg, posterior aspect.

Euchirella formosa Vervoort, 1949

Previous Tasmanian Records: Nil.

(figs $31 \mathrm{a}$ - d)

Occurrence: Station E6, May, 1973 - 1 female.

Figure Explanations:

(a) female whole animal, dorsal view,

(b) female anterior region of head, lateral view,

(c) female first leg,

(d) female fourth leg, posterior aspect (without middle and distal segments of exopodite).

\section{Euchirella rostrata (Claus)}

(figs $32 a-d$ )

Reference Specimen: Hammick and Fleminger, C.S.I.R.O., Cronulla, Bottle No. 19, Sample No. South Coast N.S.W.

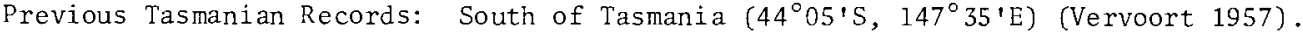

Occurrence: Inshore coasta1, Coastal and Oceanic.

Figure Explanations:

(a) female rostrum,

(b) female whole animal, lateral view,

(c) male fifth leg,

(d) female first basal segment of the fourth leg, posterior aspect.

Euchirella rostromagna (Wo1fenden, 1911)

$$
\text { (figs } 33 a-d \text { ) }
$$

Reference Specimen: Vervoort, C.S.I.R.O., Cronulla, Bottle No. 31, Sample No. Wm Barends A029.

Previous Tasmanian Records: Nil.

Occurrence: Coastal and Oceanic.

Figure Explanations:

(a) female whole animal, lateral view,

(b) female rostrum, lateral view,

(c) female first basal segment of the fourth leg, posterior aspect,

(d) female fourth leg, posterior aspect.

Euchirelza venusta Giesbrecht, 1892

$$
\text { (figs } 34 \mathrm{a} \text { - e) }
$$

Previous Tasmanian Records: Ni1.

Occurrence: Station E11, January, 1972 - 1 female.

Figure Explanations:

(a) female whole animal, dorsal view,

(b) female anterior region of head, lateral view,

(c) female last metasomal segment and urosome, lateral view,

(d) female fourth leg, posterior aspect,

(e) inner region of first basal segment of female fourth leg, posterior aspect. 


\section{Plankton of Southeastern Tasmania}

Previous Tasmanian Records: Ni1.

$$
\begin{aligned}
& \text { Euchirezza sp. } \\
& \text { (figs 35a - e) }
\end{aligned}
$$

Occurrence:- Station E 7, November, 1971 - 1 female.

Remarks: The male fifth legs of the present specimen generally resembles the fifth legs of the known species of Euchirelza. The right leg is very similar in structure to the right $1 \mathrm{eg}$ of $E$. messinensis. However, as with other species of the genus EuchirelZa, the main character which differs is the structure of the terminal part of the 5 th $1 \mathrm{eg}$. In the present specimen the outer segment of the terminal part is clawlike (fig. 35e) in appearance.

Figure Explanations:
(a) male whole animal, lateral view,
(b) male rostrum, lateral view,
(c) terminal portion of male left fifth $1 \mathrm{eg}$,
(d) male fifth leg,
(e) terminal portion of male right fifth leg.

$$
\begin{gathered}
\text { Undeuchaeta plumosa (Lobbock, 1856) } \\
\text { (figs 36a - d) }
\end{gathered}
$$

Previous Tasmanian Records: South of Tasmania ( $44^{\circ} 05^{\prime} \mathrm{S}, 147^{\circ} 35^{\prime} \mathrm{E}$ ) (Vervoort 1957). Occurrence: Coastal and Oceanic.

Figure Explanations:

(a) female whole animal, dorsal view,

(b) male fifth $1 \mathrm{eg}$,

(c) female last metosomal segment and genital segment, dorsal view,

(d) male whole animal, dorsal view.

\section{Family EUCHAETIDAE}

Euchaeta acuta Giesbrecht, 1892

Previous Tasmanian Records: Nil.

$$
\text { (figs } 37 a-1 \text { ) }
$$

Occurrence: Station E 11, December, 1971 - 8 females, I male

Station E 12, December, 1971 - 1 female, 1 male

Station E 7, November, 1972 - 4 females

Station E 6, May, 1973 - 1 male

Figure Explanations:

(a) female whole anima1, dorsal view,

(b) female genital segment, lateral view,

(c) exopodite of female fourth $1 \mathrm{eg}$,

(d) rostrum, latera 1 view,

(e) exopodite of female first leg,

(f) apical spine of the second maxilla,

(g) male whole animal, dorsal view,

(h) male furcal rami, dorsal view,

(i) male rostrum, lateral view,

(j) male fifth leg,

(k) portion of distal segments of male left fifth leg,

(1) portion of distal segment of male left fifth leg. (another specimen).

\section{Family PHAENNIDAE}

Phaenna spinifera Claus, 1863

$$
\text { (figs } 38 \mathrm{a}-\mathrm{d} \text { ) }
$$

Previous Tasmanian Records: Nil.

Occurrence: Station E 5, May, 1973 - 1 fernale. 


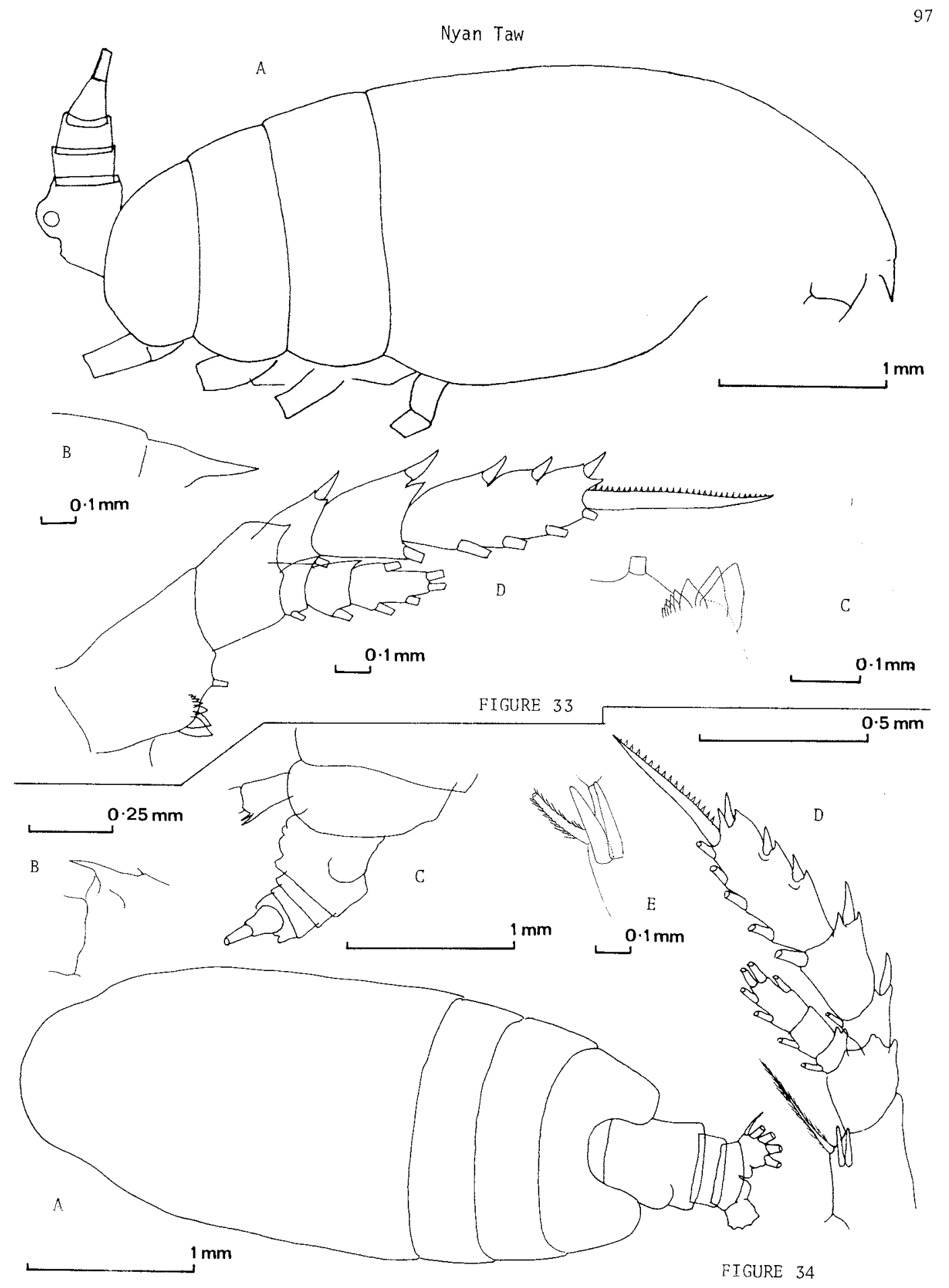


Plankton of Southeastern Tasmania

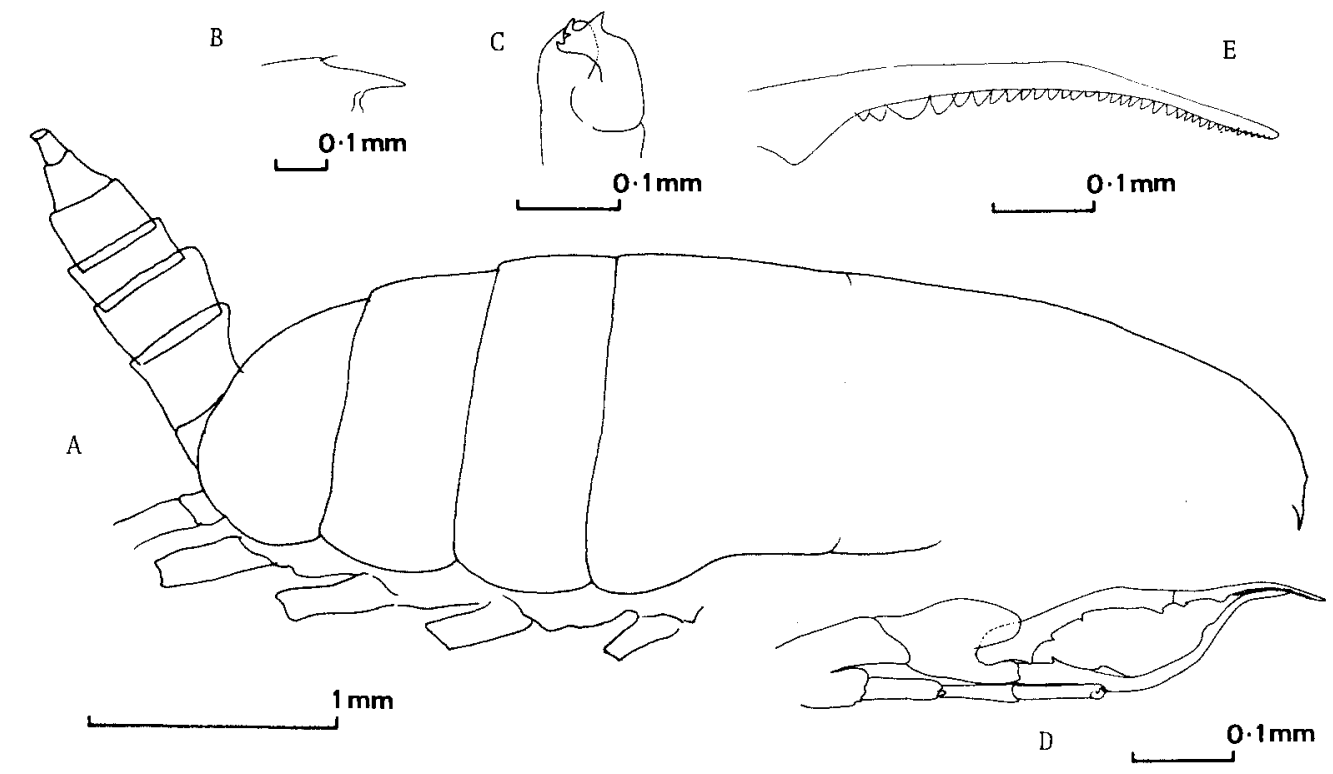

FIGURE 35

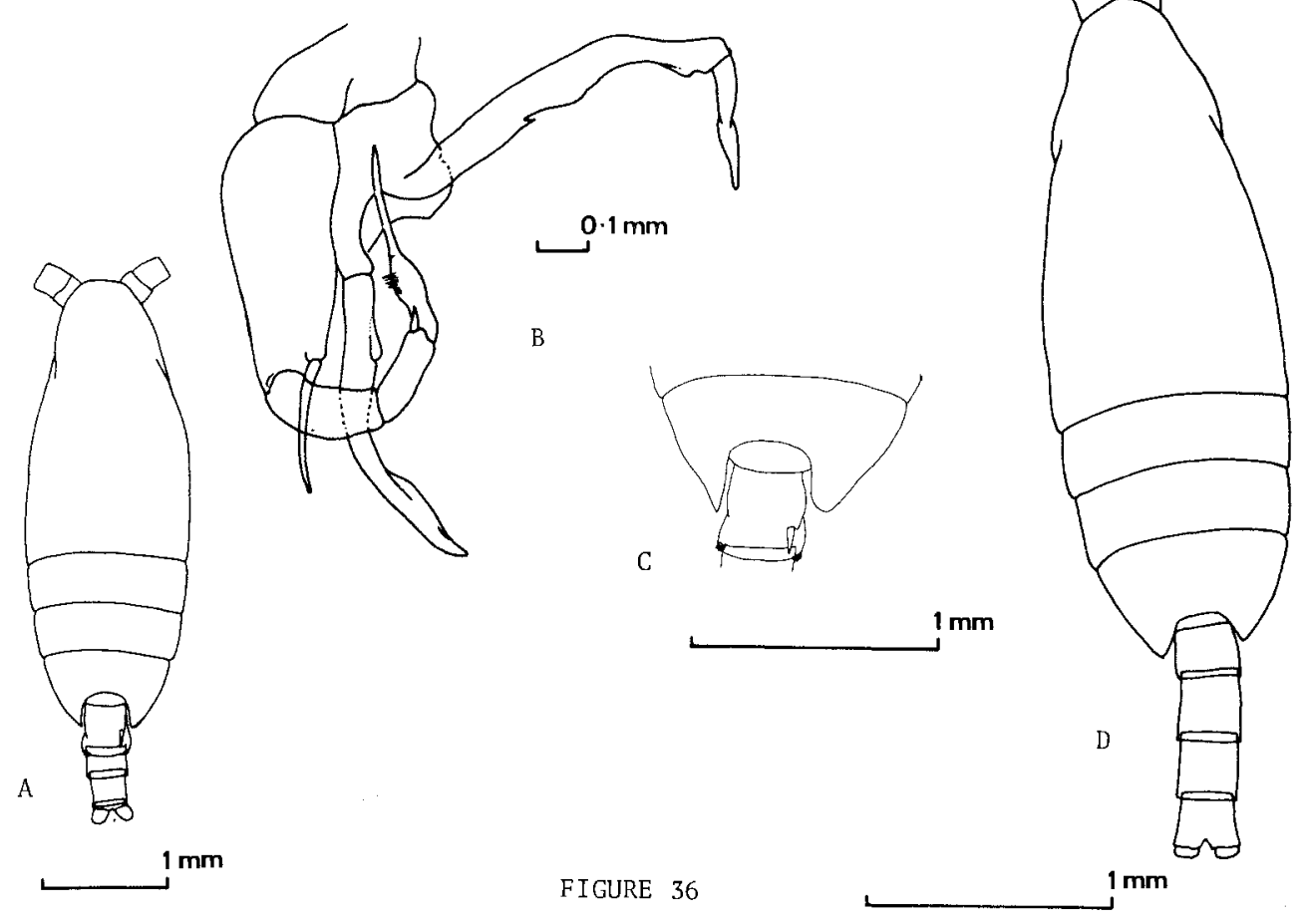




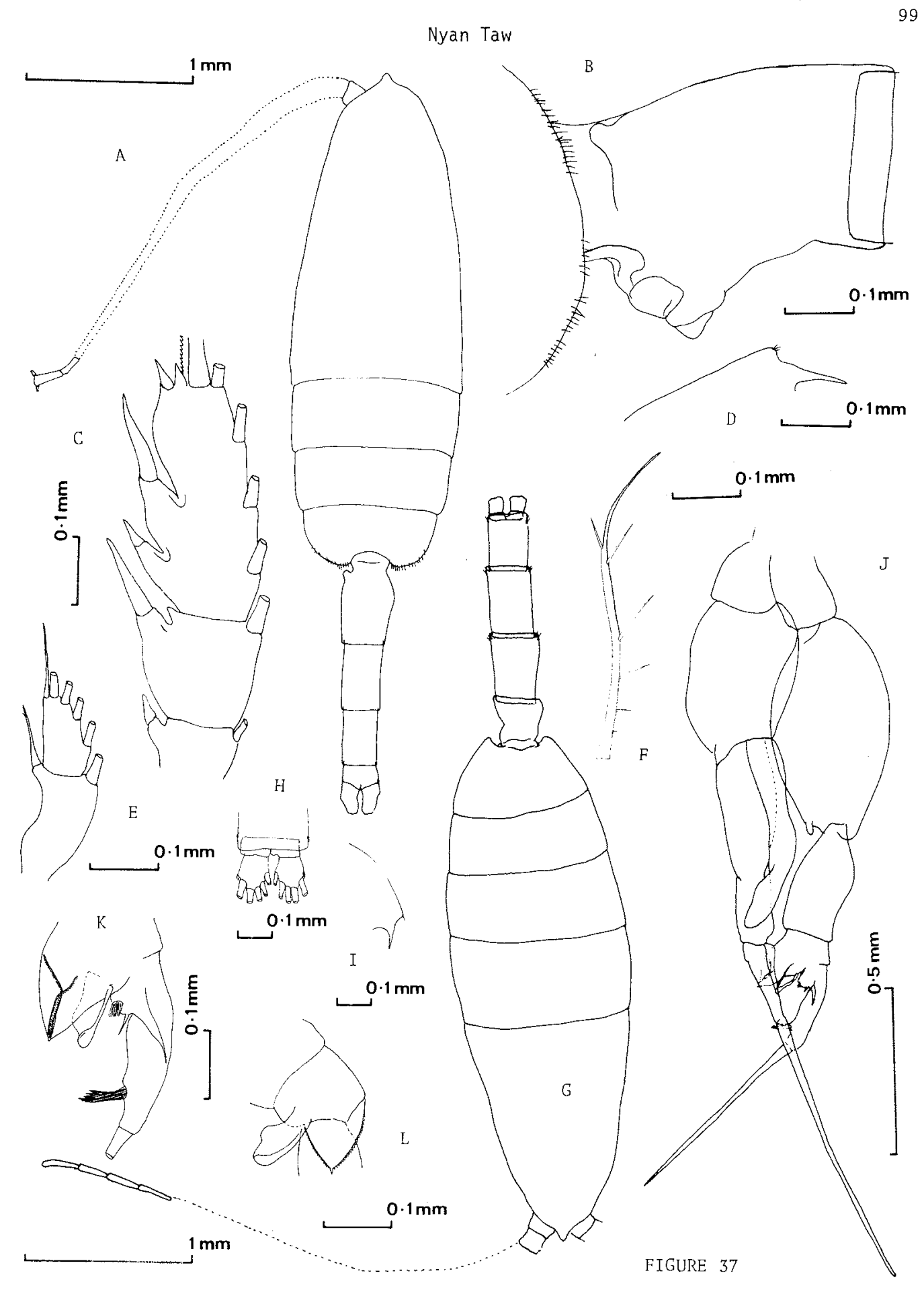


Plankton of Southeastern Tasmania

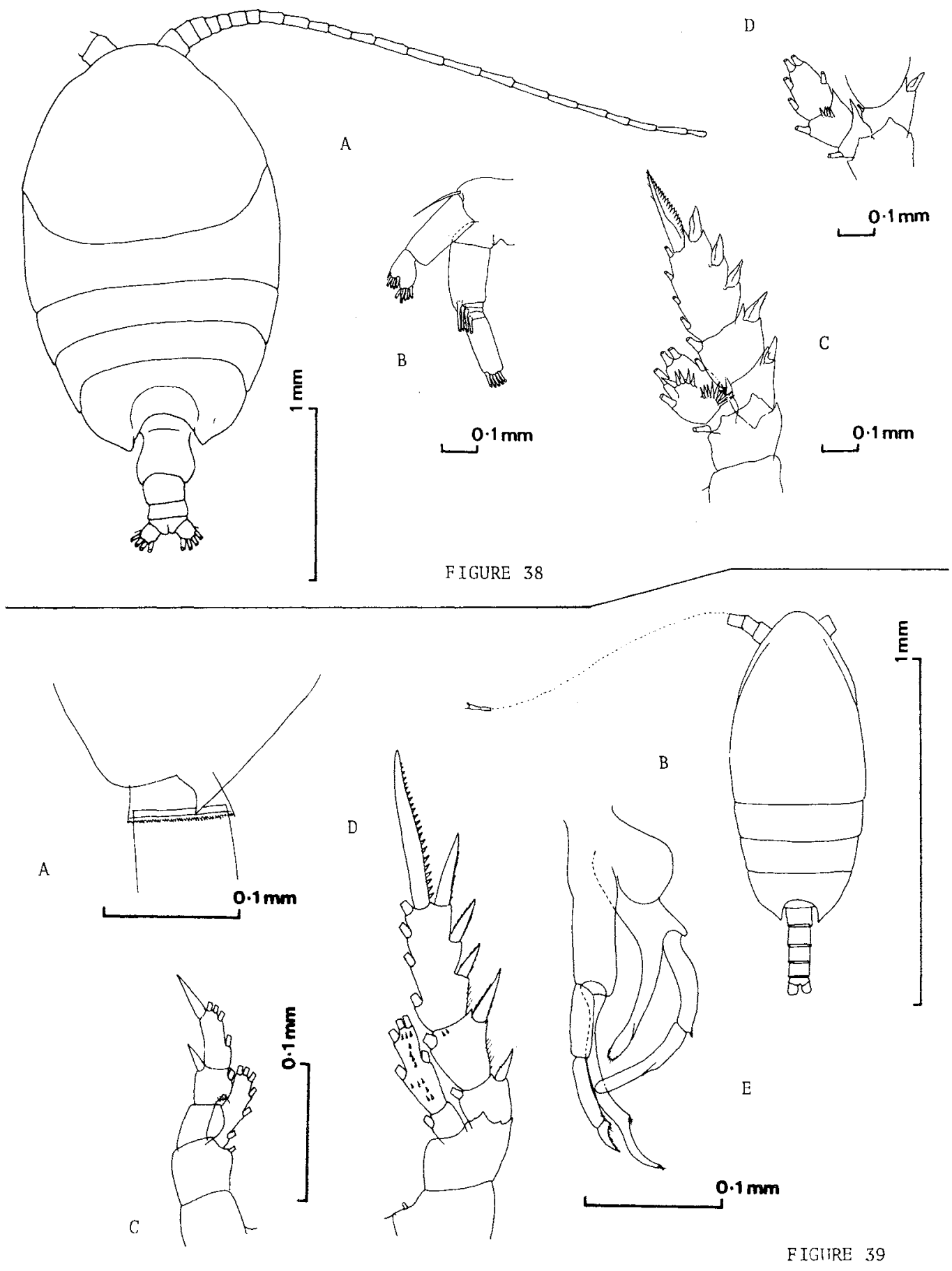


Figure Explanations:

(a) female whole animal, dorsal view,

(b) female second antenna,

(c) female second leg, posterior aspect,

(d) endopod and proximal exopodite segment of female fourth leg, posterior aspect.

\section{Family SCOLECITHRICIDAE}

Racorvitzanus sp.

(figs $39 a-e)$

Previous Tasmanian Records: Nil.

Occurrence: Station IC 3, December, 1971, midwater night plankton tow - 1 male.

Figure Explanations:

(a) male posterior boarder of last metasomal segment and lateral view,

(b) male whole animal, dorsal view,

(c) male first leg, posterior aspect,

(d) male second leg, posterior aspect,

(c) male fifth leg.

\section{Scolecithrix bradyi Geisbrecht}

$$
\text { (figs 40a-c) }
$$

Previous Tasmanian Records: Nil.

Occurrence: Station E 7, November, 1971 - 3 females

Station E 12, November, 1971 - 1 male

Station E 2, November, 1972 - 1 female

Figure Explanations:

(a) male whole animal, dorsal view,

(b) male fifth leg,

(c) female whole animal, lateral view.

Scolecithrix danae (Lubbock, 1856)

Previous Tasmanian Records: Nil.

(figs $41 \mathrm{a}-\mathrm{d}$ )

Occurrence: Station E 9, October, 1972 - 1 male and 1 female.

Figure Explanations:

(a) male whole animal, dorsal view,

(b) male fifth $1 \mathrm{eg}$,

(c) female posterior region of metasome and urosome, lateral view.

\section{Fami $1 Y$ CENTROPAGIDAE}

Boeckelza triartioulata (Thomson, 1883)

$$
\text { (figs } 42 \mathrm{a}-\mathrm{f} \text { ) }
$$

Previous Tasmanian Records: Freshwater Lakes and Lagoons of Tasmania (Bayly 1964) Figure Exp1anations:

(a) female whole animal, lateral view,

(b) male last metasomal segment and urosome, dorsal view,

(c) female fourth leg,

(d) process on the middle exopodite segment of female fourth leg,

(e) male fifth leg,

(f) inner region of second basal segment of male fifth leg and endopodite.

\section{Centropages australiensis Fairbridge, 1944}

$$
\text { (figs } 43 \mathrm{a}-\mathrm{d} \text { ) }
$$

Previous Tasmanian Records: Mouth of River Derwent (Ong 1967).

Occurrence: Inshore coastal, Coastal and Oceanic. 
Figure Explanations:

(a) female whole animal, dorsal view,

(b) male last metasomal segment and urosome, dorsal view,

(c) male right fifth leg,

(d) female fifth leg.

Centropages bradyi (Wheeler, 1899)

(figs $44 a-c$ )

Previous Tasmanian Records: South of Tasmania $44^{\circ} 05^{\prime} \mathrm{S}, 147^{\circ} 35^{\prime} \mathrm{E}$ (Vervoort 1957).

Occurrence: Inshore coastal, Coastal and Oceanic.

Figure Explanations:

(a) female whole animal, dorsal view,

(b) male right fifth leg,

(c) female fifth leg.

Previous Tasmanian Records: Nil.

GLadioferens inermis Nicholls, 1944

(figs $45 a-h$ )

Occurrence: Estuarine, Inshore coastal.

Figure Explanations:

(a) male whole animal, lateral view,

(b) male fifth leg,

(c) male second leg,

(d) male right first and second exopodite,

(e) female whole animal, dorsal view,

(f) female urosome, ventral view,

(g) female fifth leg,

(h) female fourth leg.

GLadioferens pectinatus (Brady, 1883)

(figs $46 a-h$ )

Previous Tasmanian Records: River Derwent estuary (Nicholls 1956, Ong 1967).

Occurrence: Estuarine, Inshore coastal.

Figure Explanations:

(a) male whole animal, dorsal view,

(b) male fifth leg,

(c) inner junction of proximal and middle segments of exopodite of male right

(d) (e) fifth leg - variation in form of distal projection,

(f) female whole animal, lateral view,

(g) female fifth leg,

(h) female urosome ventral view.

Gladioferens spinosus Henry, 1922

(figs $47 a-e$ )

Previous Tasmanian Records: Big Lake Waterhouse (Brehm, 1953).

Occurrence: Estuarine.

Figure Explanations:

(a) female whole animal, dorsal view,

(b) posterior portion of metasome and genital segment of female, dorsal view,

(c) male last metasomal segment and urosome, dorsal view,

(d) male fifth leg,

(e) process on the inner proximal exopodite segment of male right fifth leg.

\section{Gladioferens symmetrious Bayly, 1963}

$$
\text { (figs } 48 \mathrm{a}-\mathrm{d} \text { ) }
$$

Previous Tasmanian Records: Nil.

Occurrence: Mouth of North West Bay River, D'Entrecasteaux Channel. 


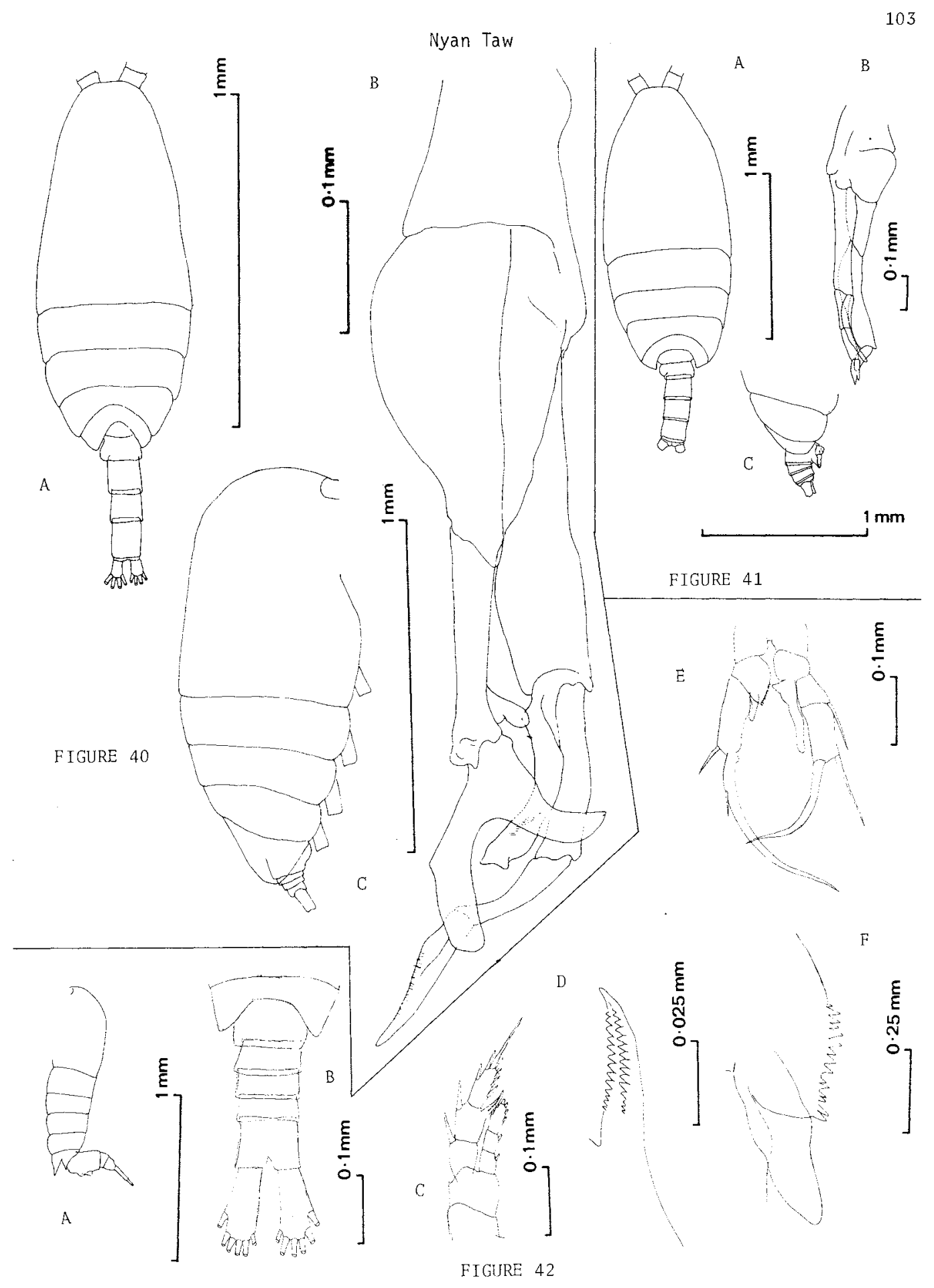


Plankton of Southeastern Tasmania

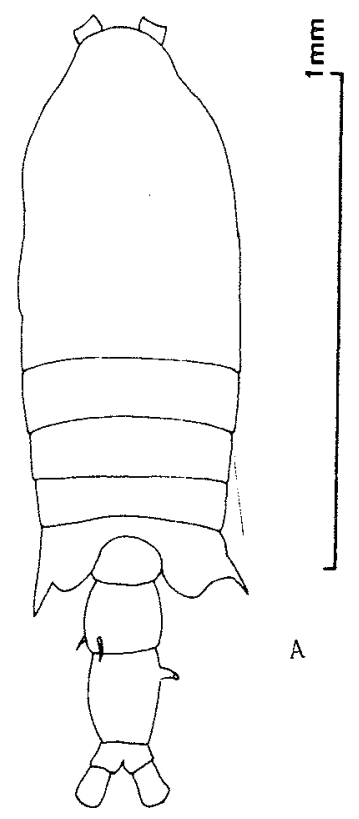

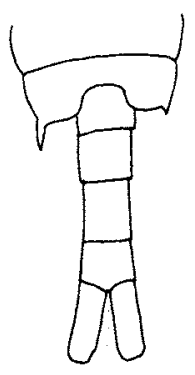

B

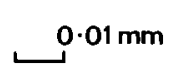

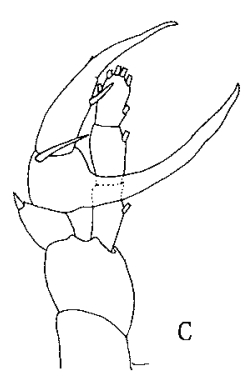

$0.1 \mathrm{~mm}$

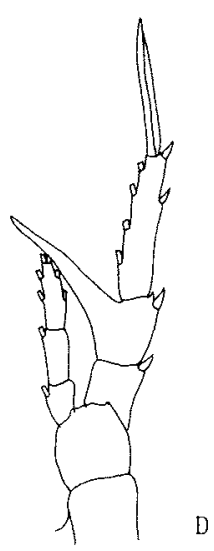

$0.1 \mathrm{~mm}$

FIGURE 43

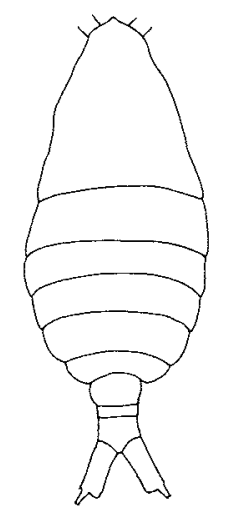

A
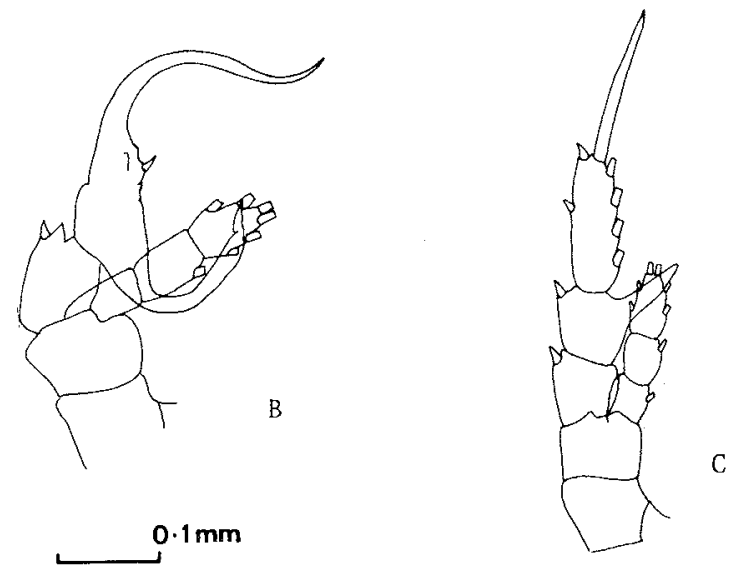

$1 \mathrm{~mm}$
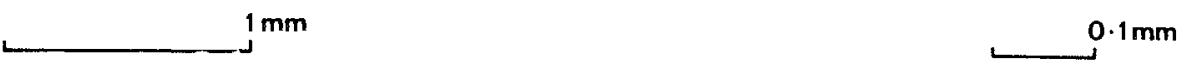

F IGURE 44 


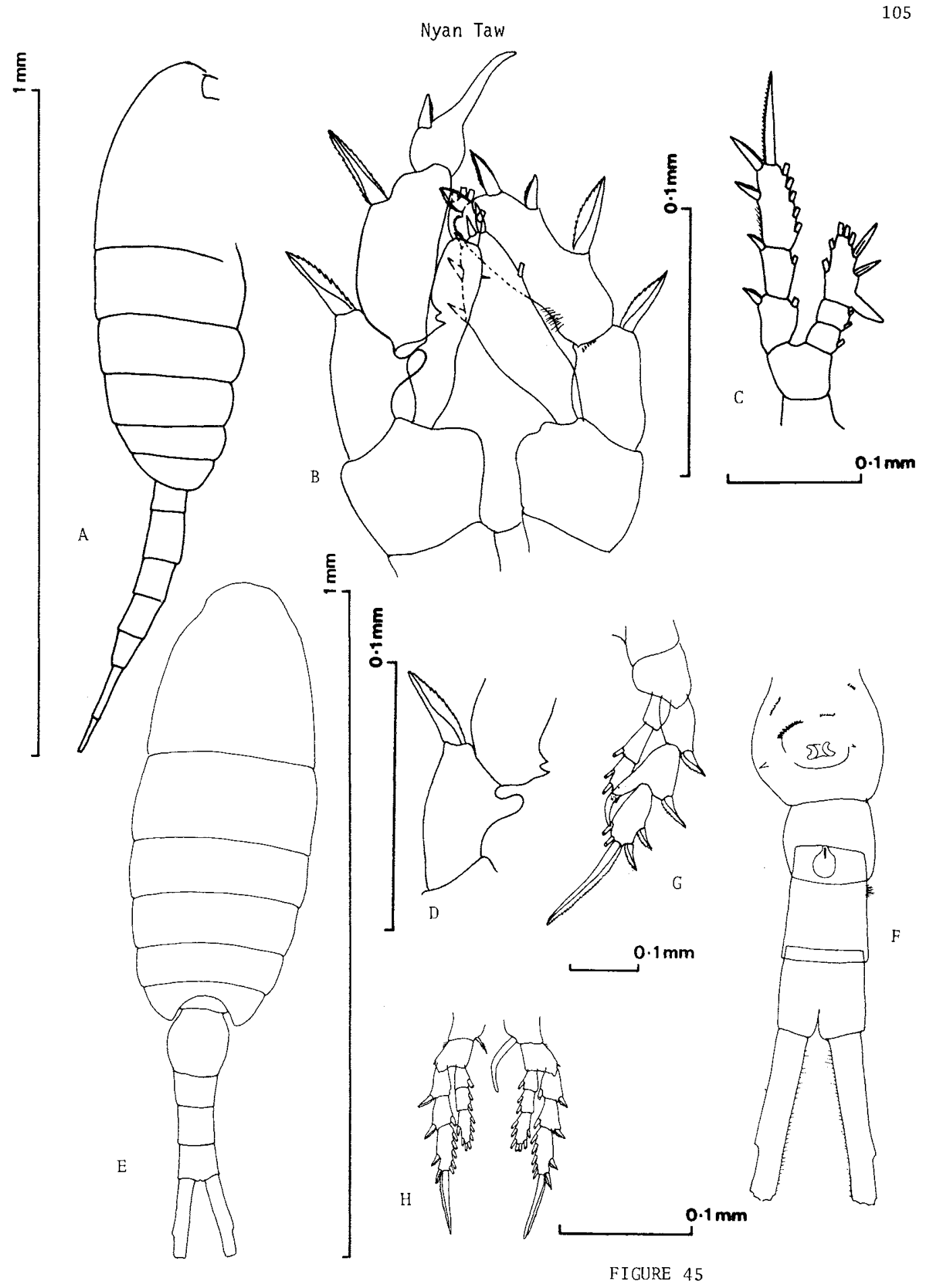


Plankton of Southeastern Tasmania

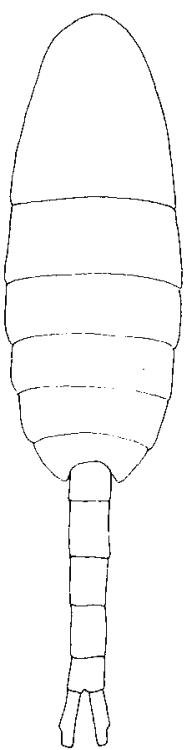

A

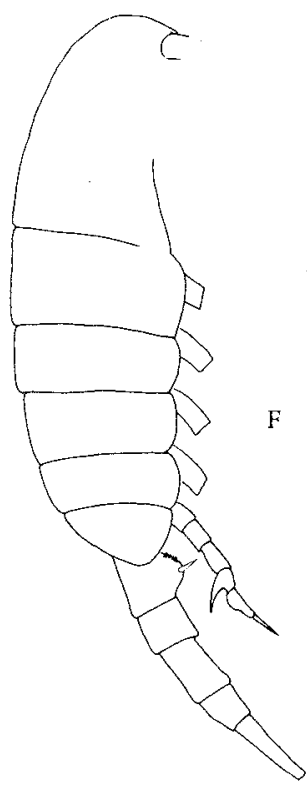

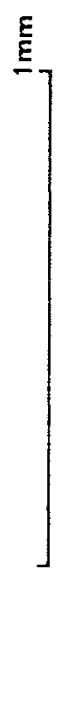
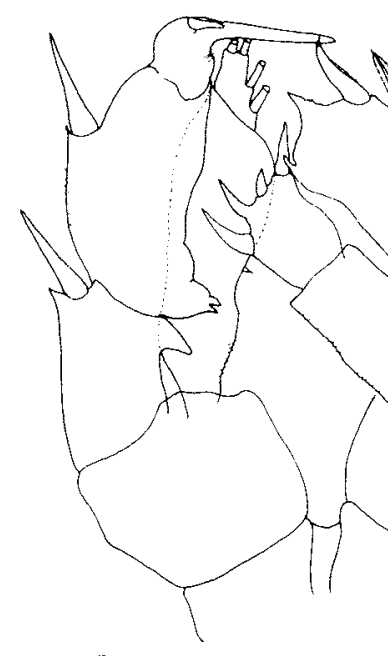

B
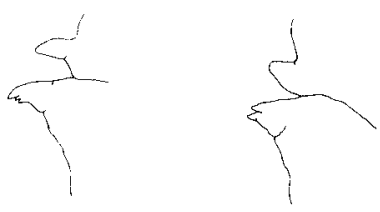

C

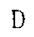

D

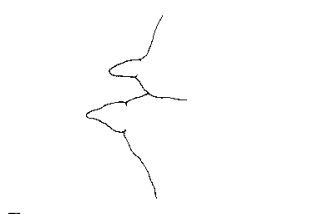

E

$0.1 \mathrm{~mm}$ $0.1 \mathrm{~mm}$

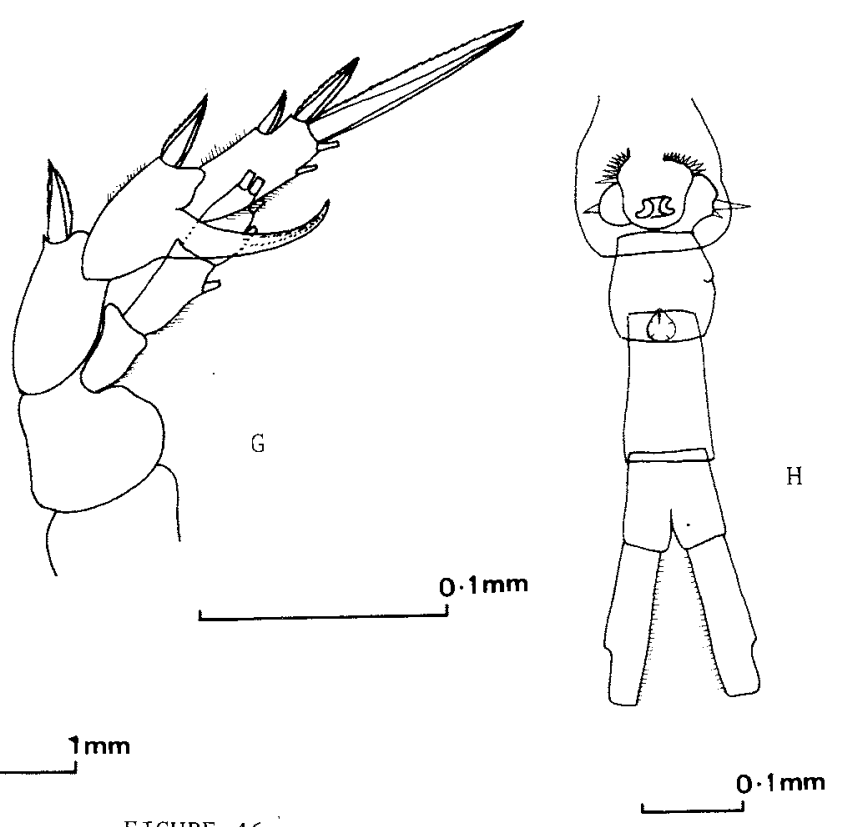

FIGURE 46 


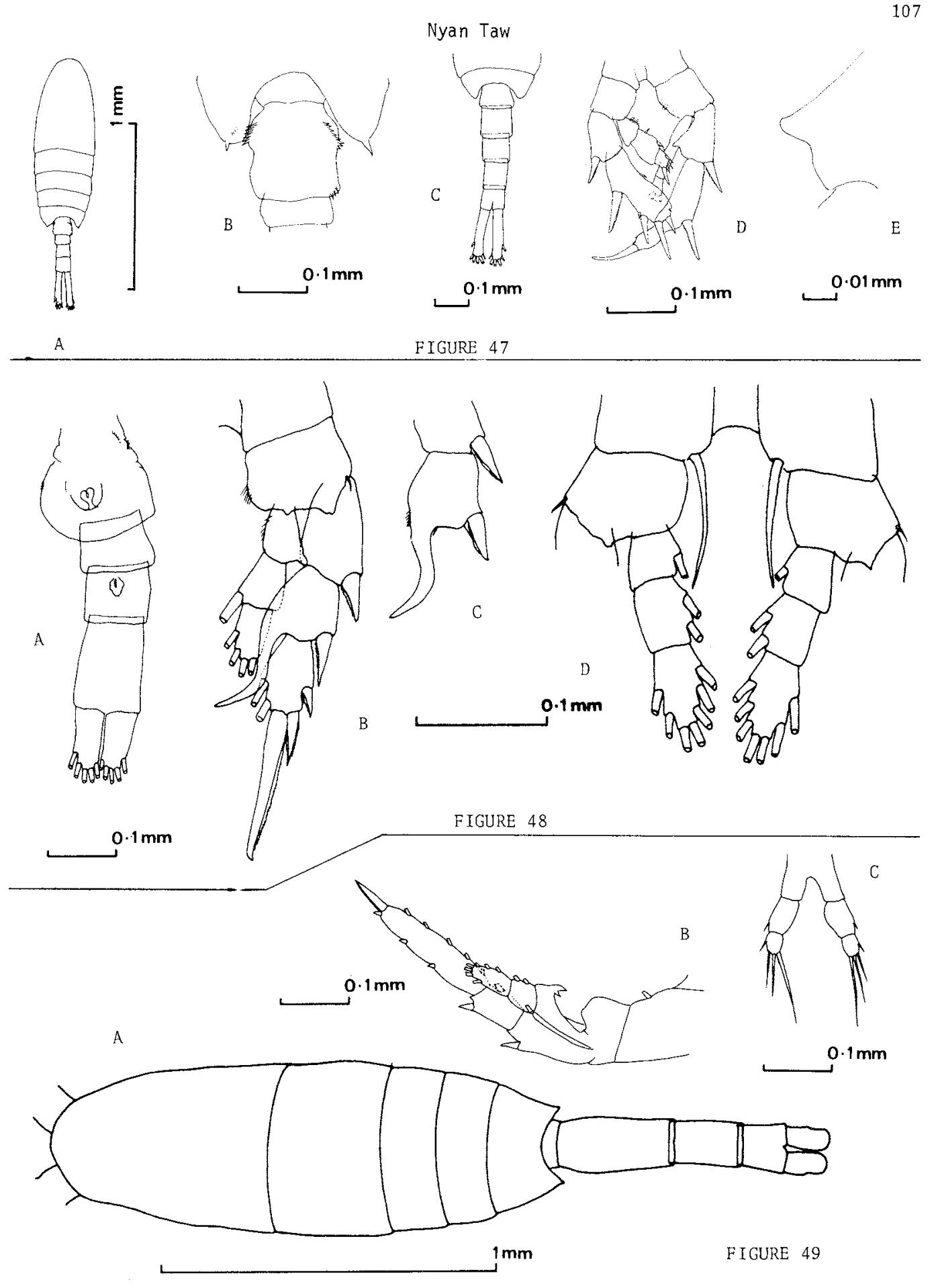



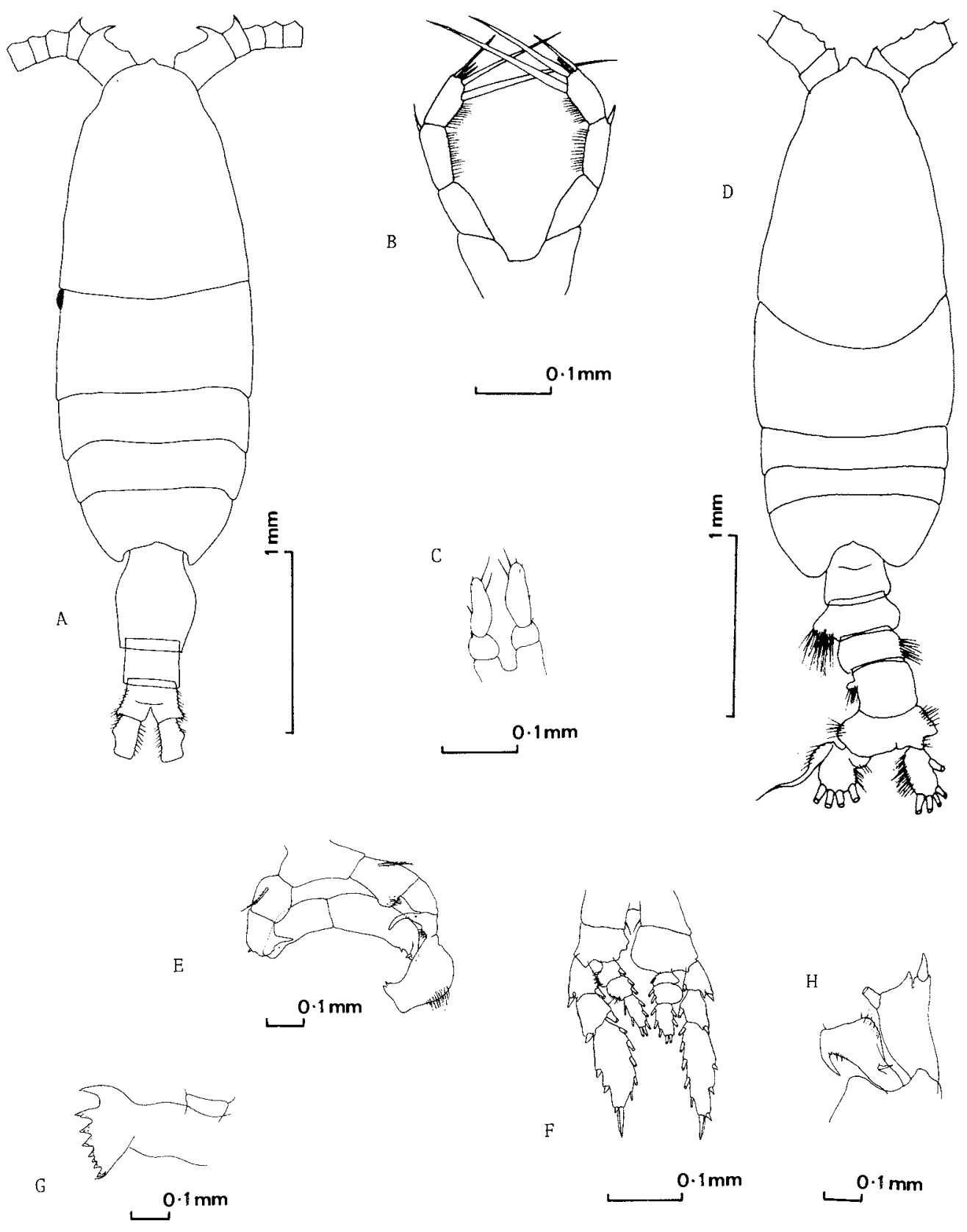

F IGURE 50 
Nyan Taw

Figure Explanations:

(a) female urosome, ventral view,

(b) female fifth leg,

(c) middle exopodite segment of female fifth leg,

(d) female second leg without expodite.

Family METRIDIIDAE

Metridia Zucens (Boeck, 1863)

(figs 49a - c)

Previous Tasmanian Records: Nil.

Occurrence: Station IC 3, June, 1972 - 1 female.

Figure Explanations:

(a) female whole animal, dorsal view,

(b) female second $1 \mathrm{eg}$, posterior aspect,

(c) female fifth $1 \mathrm{eg}$.

Pleuromama abdominalis (Lubbock, 1856)

(figs $50 a-h$ )

Previous Tasmanian Records: South of Tasmania ( $44^{\circ} 05^{\prime} \mathrm{S}, 147^{\circ} 35^{\circ} \mathrm{E}$ ) (Vervoort 1957). Occurrence: Inshore coastal, Coastal and Oceanic.

Figure Explanations:

(a) female whole anima1, dorsal view,

(b) female fifth $1 \mathrm{eg}$,

(c) immature female fifth $1 \mathrm{eg}$,

(d) male whole animal, dorsal view,

(e) male fifth leg,

(f) male fourth $1 \mathrm{eg}$,

(g) male mandible,

(h) proximal segments of male right second $1 \mathrm{eg}$.

Pleuromarma gracilis (C1aus, 1893)

(figs $51 \mathrm{a}-\mathrm{d}$ )

Previous Tasmanian Records: South of Tasmania (44 $05^{\prime} \mathrm{S}, 147^{\circ} 35^{\prime} \mathrm{E}$ ) (Vervoort 1957). Occurrence: Inshore coasta1, Coastal and Oceanic.

Figure Explanations:

(a) female whole animal, dorsal view,

(b) female genital segment, lateral view,

(c) female fifth $1 \mathrm{eg}$,

(d) male fifth leg.

Pleuromama xiphias (Giesbrecht, 1889)

(figs $52 \mathrm{a}$ - f)

Previous Tasmanian Records: South of Tasmania ( $44^{\circ} 05^{\prime} \mathrm{S}, 147^{\circ} 35^{\prime} \mathrm{E}$ ) (Vervoort 1957). Occurrence: Station E 6, May, 1973 - 6 males.

Figure Explanations:

(a) male whole animal, lateral view,

(b) male urosome, dorsal view,

(c) anterior region of male head, lateral view,

(d) proximal segments of male right first antenna,

(e) male fifth $1 \mathrm{eg}$,

(f) male right second leg with part of $1 \mathrm{eft} 1 \mathrm{eg}$. 
Previous Tasmanian Records: Nil.

(a) female whole animal, dorsal view,

(b) male fifth legs,

(c) female fifth legs,

(d) female fourth leg, posterior aspect.

Family PSEUDODIAPTOMIDAE

Pseudodioptomus cornutus Nicholls, 1944

Previous Tasmanian Records: Nil.

$$
\text { (figs } 54 \mathrm{a}-\mathrm{g} \text { ) }
$$

Occurrence: Inshore coastal.

Figure Explanations:

(a) male whole animal, lateral view,

(b) male right first antenna,

(c) male fifth leg,

(d) female whole animal, lateral view,

(e) female fifth legs,

(f) female last metasomal segment and genital segment,

(g) female fourth leg, posterior aspect.

Family LUCICUTIIDAE

Lucicutia flaviconnis (C1aus, 1863)

Previous Tasmanian Records: Nil.

Occurrence: Inshore coastal, Coastal and Oceanic.

Figure Explanations:

(a) female whole animal, dorsal view,

(b) female fifth leg,

(c) male fifth leg.

\section{Fami $1 Y$ HETERORHABDIDAE}

Heterorhabdus poppizliger (CIaus, 1863)

$$
\text { (figs } 56 a-e)
$$

Previous Tasmanian Records: Nil.

Occurrence: Inshore Coastal, Coastal and Oceanic.

Figure Explanations:

(a) male whole animal, dorsal view,

(b) male fifth leg,

(c) female posterior region of metasome and urosome, lateral view,

(d) female second maxilla,

(e) female fifth leg.

\section{Family CANDACIIDAE}

Candacia armata (Boeck, 1863)

Previous Tasmanian Records: Ni1.

$$
\text { (figs } 57 a-e)
$$




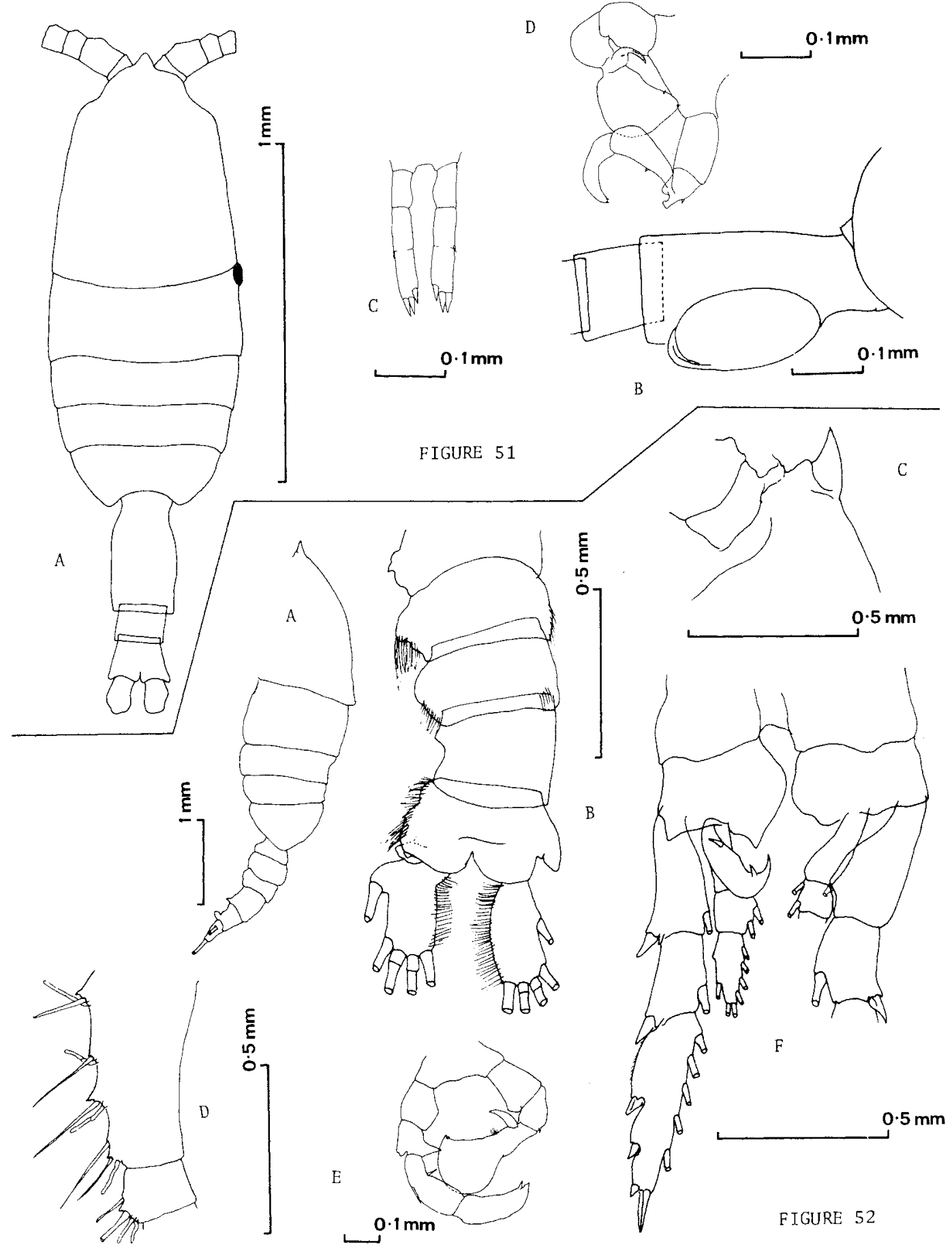


Plankton of Southeastern Tasmania

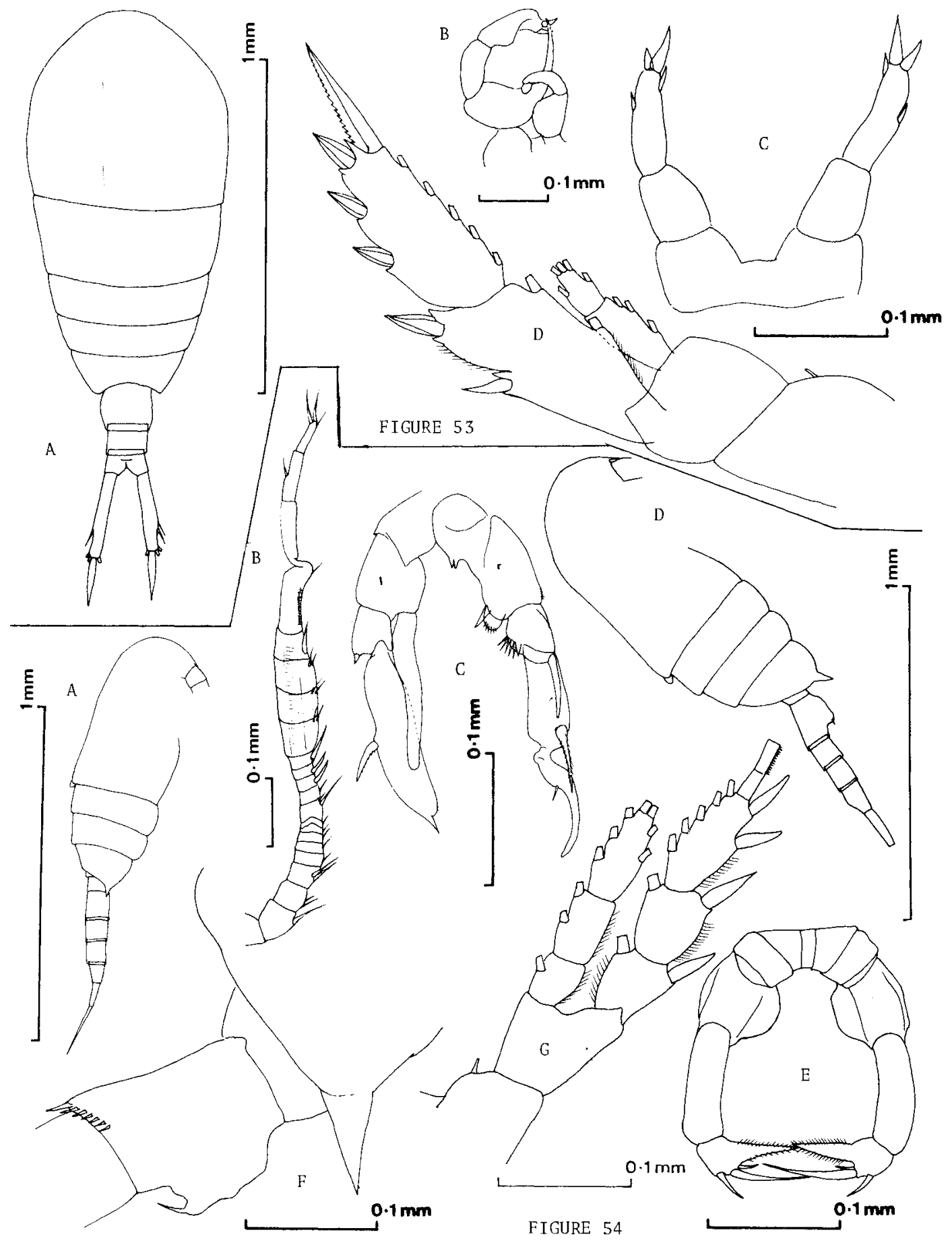




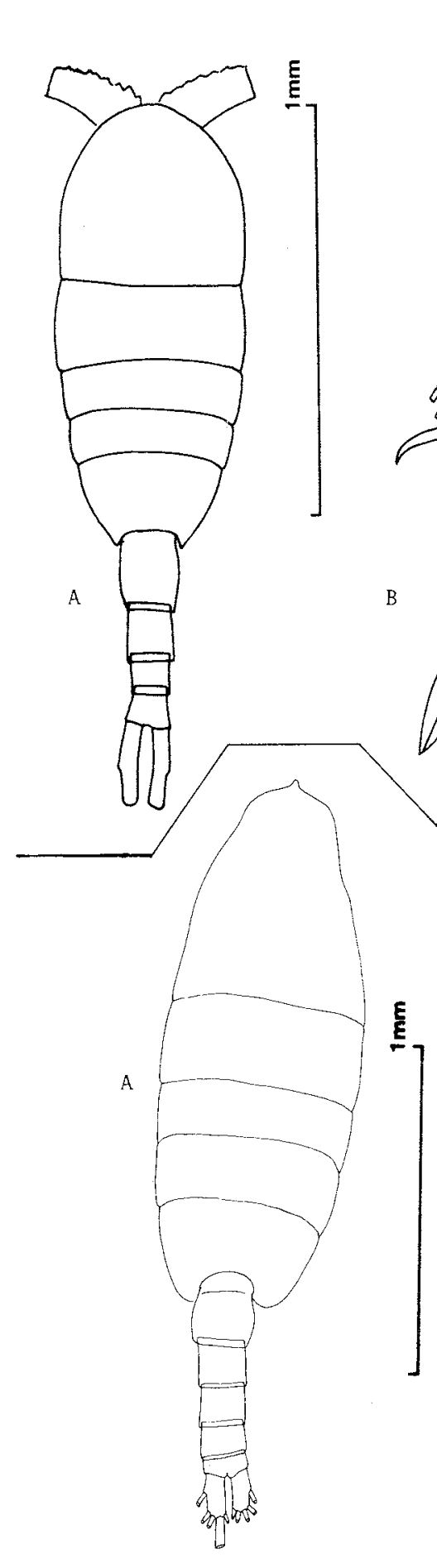

Nyan Taw
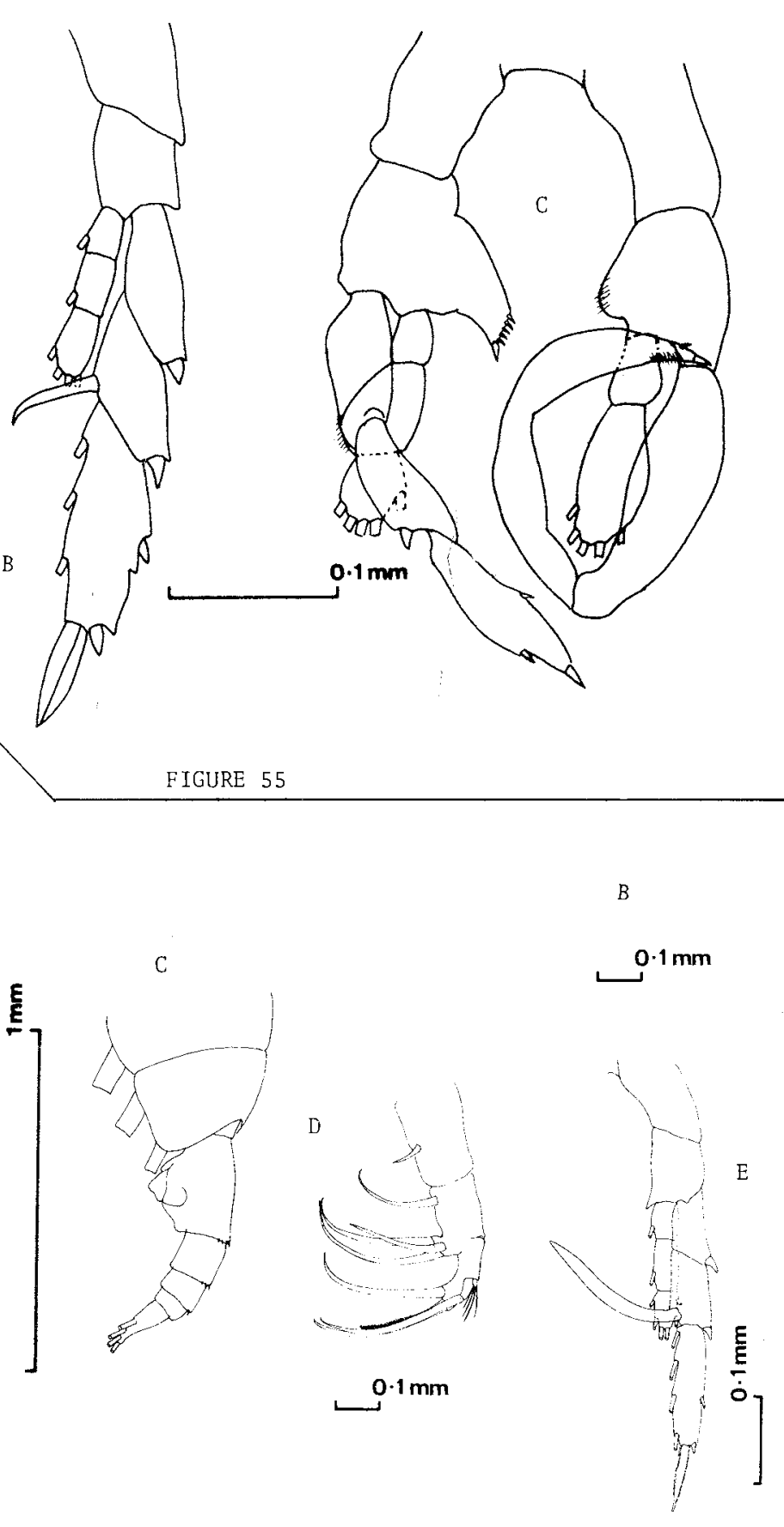

FIGURE 56 
Plankton of Southeastern Tasmania

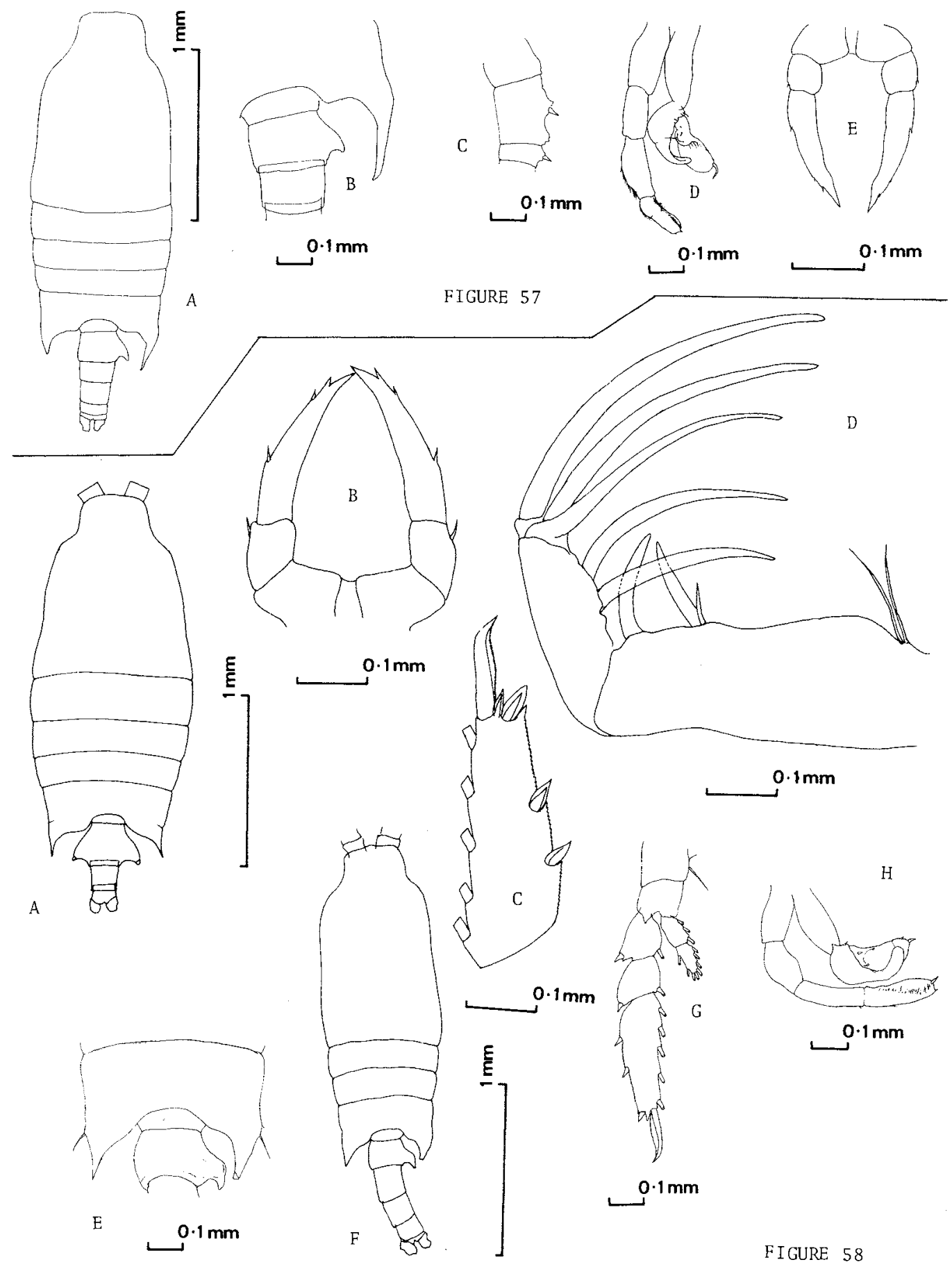




\section{Nyan Taw}

Occurrence: Station IC 3, September, 1971 - 1 female

Station E 11, November, 1972 - 1 male

Figure Explanations:

(a) male whole anima1, dorsal view,

(b) posterior portion of metasome and anterior portion of urosome of male, dorsal view,

(c) proximal segments of male right first antenna,

(d) male fifth leg,

(e) female fifth 1 eg.

Candacia bipinnata (Giesbrecht, 1888)

Previous Tasmanian Records: Nil.

Occurrence: Inshore coastal, Coastal and Oceanic.

Figure Explanations:

(a) female whole animal, dorsal view,

(b) female fifth 1 eg,

(c) terminal exopodite segment of male third leg,

(d) female first maxilliped,

(e) male last metasomal segment and first urosomal segment, dorsal view,

(f) male whole animal, dorsal view,

(g) male third leg:

(b) male fifth leg.

Candacia tenuimana (Giesbrecht, 1888)

(figs $59 a-d)$

Previous Tasmanian Records: Nil.

Occurrence: Station E 1, November, 1972 - 1 male.

Figure Explanations:

(a) male whole animal, dorsal view,

(b) posterior portion of male metasome and first urosomal segment, dorsal view,

(c) male left fifth $1 \mathrm{eg}$,

(d) male right fifth leg.

\section{Poracandacia simplex (Giesbrecht)}

Previous Tasmanian Records: Nil.

$$
\text { (figs } 60 a-c \text { ) }
$$

Occurrence: Station E 1, October, 1972 - 1 female.

Figure Explanations:

(a) female whole animal, dorsal view,

(b) female fifth $1 \mathrm{eg}$,

(c) female terminal exopodite segment of third leg.

\section{Fami Iy PONTELLIDAE}

Labidocera cervi Kramer, 1895

$$
\text { (figs 6la - g) }
$$

Previous Tasmanian Records: D'Entrecasteaux Channel (Ong, 1970).

Occurrence: Station IC 1, February, 1972 - 1 female. Off Roberts Point, D'Entrecasteaux Channe1 - 2 females, 3 males.

Figure Explanations:

(a) female whole animal, dorsal view,

(b) female last metasomal segment and urosome, lateral view,

(c) female mandible,

(d) female fifth leg,

(e) male last metasomal segment and urosome, dorsal view,

(f) male fifth leg,

(g) male terminal segments of right first antenna. 
116

\section{Plankton of Southeastern Tasmania}

Labidocera tasmanica Nyan Taw, 1974

(figs $62 \mathrm{a}-\mathrm{g}$ )

Previous Tasmanian Records: Storm Bay, Mouth of River Derwent and Northern parts of D'Entrecasteaux Channe1 (Nyan Taw 1974).

Occurrence: Inshore coastal and Coastal.

Figure Explanations:

(a) female whole anima1, dorsal view,

(b) female last metasomal segment and urosome, lateral view,

(c) male whole animal, dorsal view,

(d) male whole anima1, latera1 view,

(e) female fifth leg, posterior aspect,

(f) male fifth leg, posterior aspect,

(g) proximal expansion of distal segment of male right fifth leg.

\section{Fami1y ACARTIIDAE}

Acartia tranteri Bradford 1976

$$
\text { (figs } 63 \mathrm{a}-\mathrm{d} \text { ) }
$$

Reference Specimen: Tranter and Hammick, C.S.I.R.0., Cronulla, Bottle No. 12. Previous Tasmanian Records: Derwent River Estuary (Ong 1967 as A. clausi). Occurrence: Estuarine, Inshore coasta1, Coastal and Oceanic.

Identified as $A$. clausi, by Ong. Present specimens resemble $A$. tranteri and this name will be retained pending specialist examination.

Figure Explanations:
(a) female whole animal, dorsal view,
(b) male whole animal, dorsal view,
(c) female fifth leg,
(d) male fifth leg.

\section{Acartia danae Giesbrecht 1889}

$$
\text { (figs 64a - d) }
$$

Reference Specimen: Tranter and Hammick, C.S.I.R.O., Cronulla, Bottle No. 20. Previous Tasmanian Records: Nil.

Occurrence: Inshore coastal, Coastal and Oceanic.

Figure Explanations:

(a) female whole animal, dorsal view,

(b) female fifth leg,

(c) female second $1 \mathrm{eg}$,

(d) female fourth leg, posterior aspect.

\section{SuZcanus conflictus Nicholls, 1945}

$$
\text { (figs 65a - d) }
$$

Previous Tasmanian Records: Derwent Estuary (Ong 1967, 1970). Occurrence: Estuarine and Inshore coasta1.

Figure Exp1anations:
(a) female whole anima1, lateral view,
(b) female fourth $1 \mathrm{eg}$,
(c) female fifth leg,
(d) male fifth leg.

Order CYCLOPOIDA

Fami1y OITHONIDAE

(figs 66a - f) 


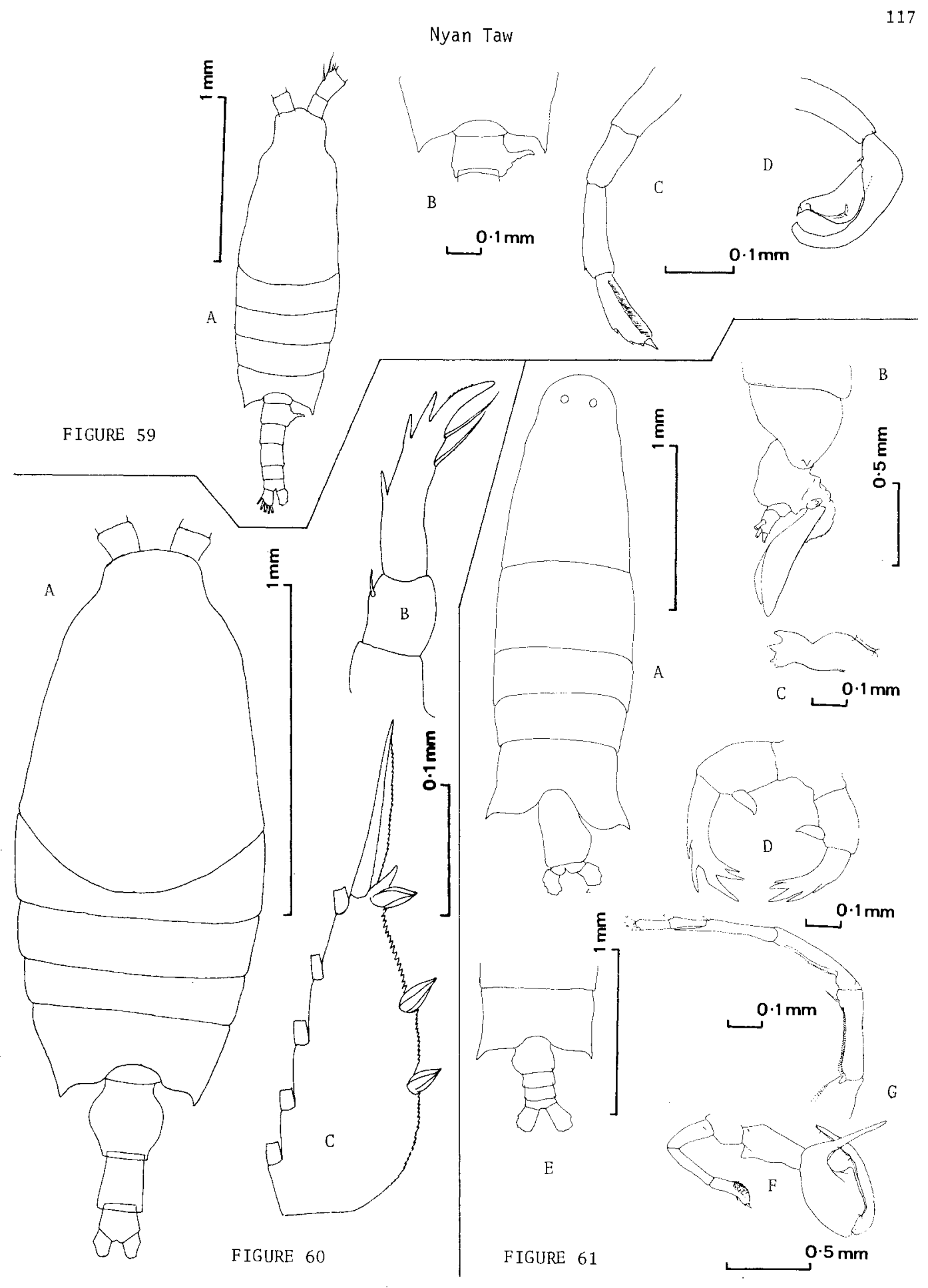


Plankton of Southeastern Tasmania

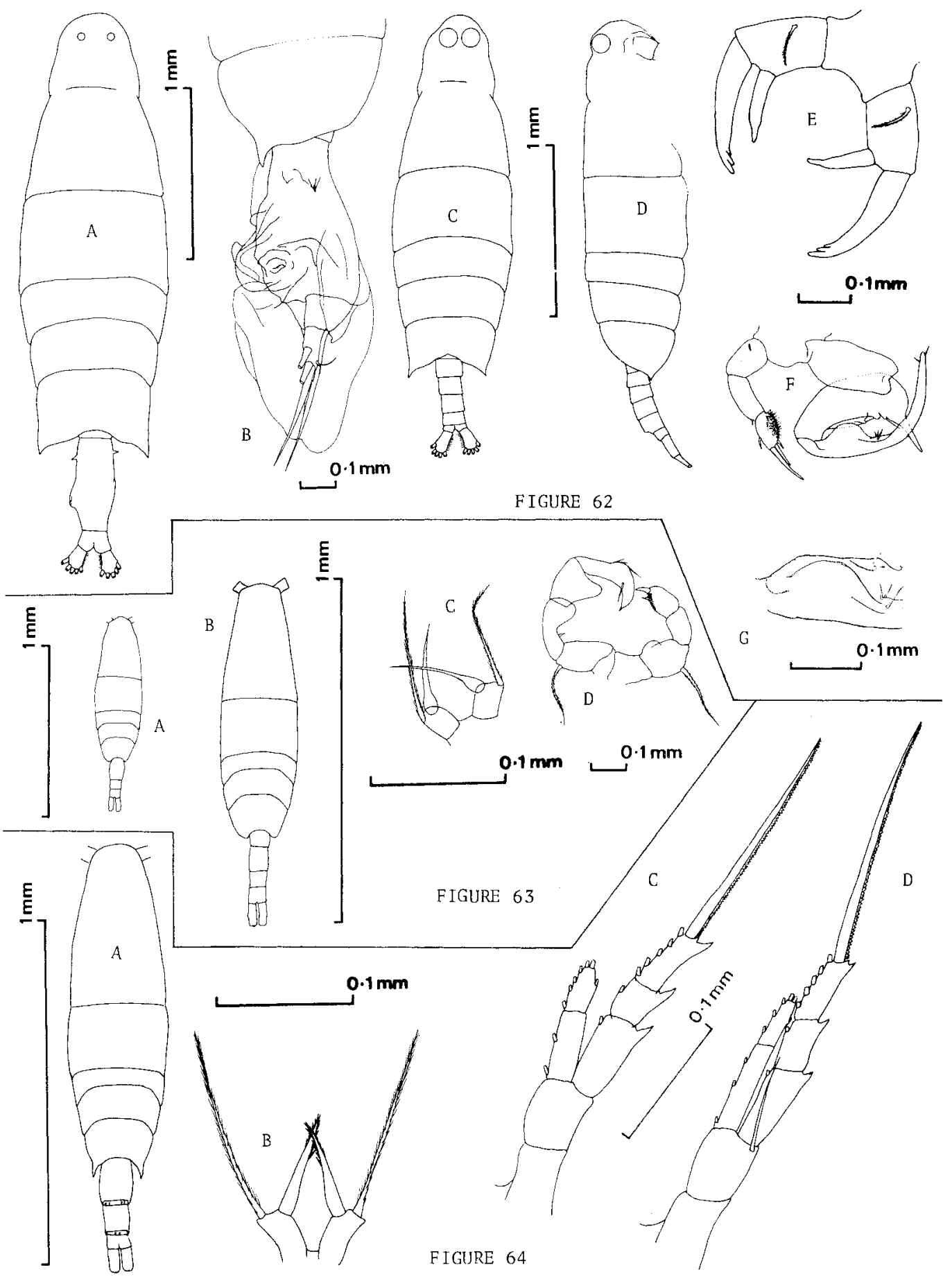


Nyan Taw

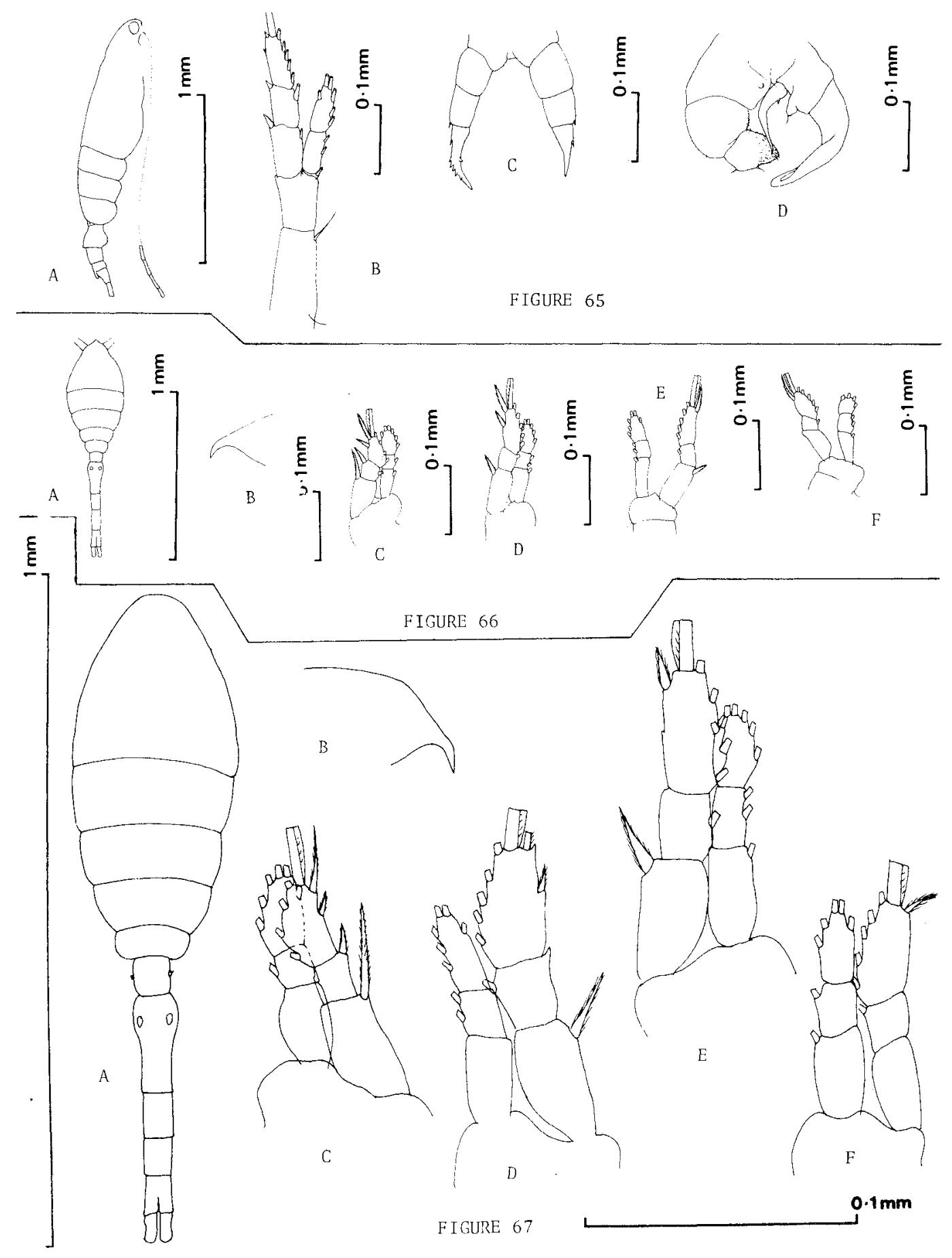


120

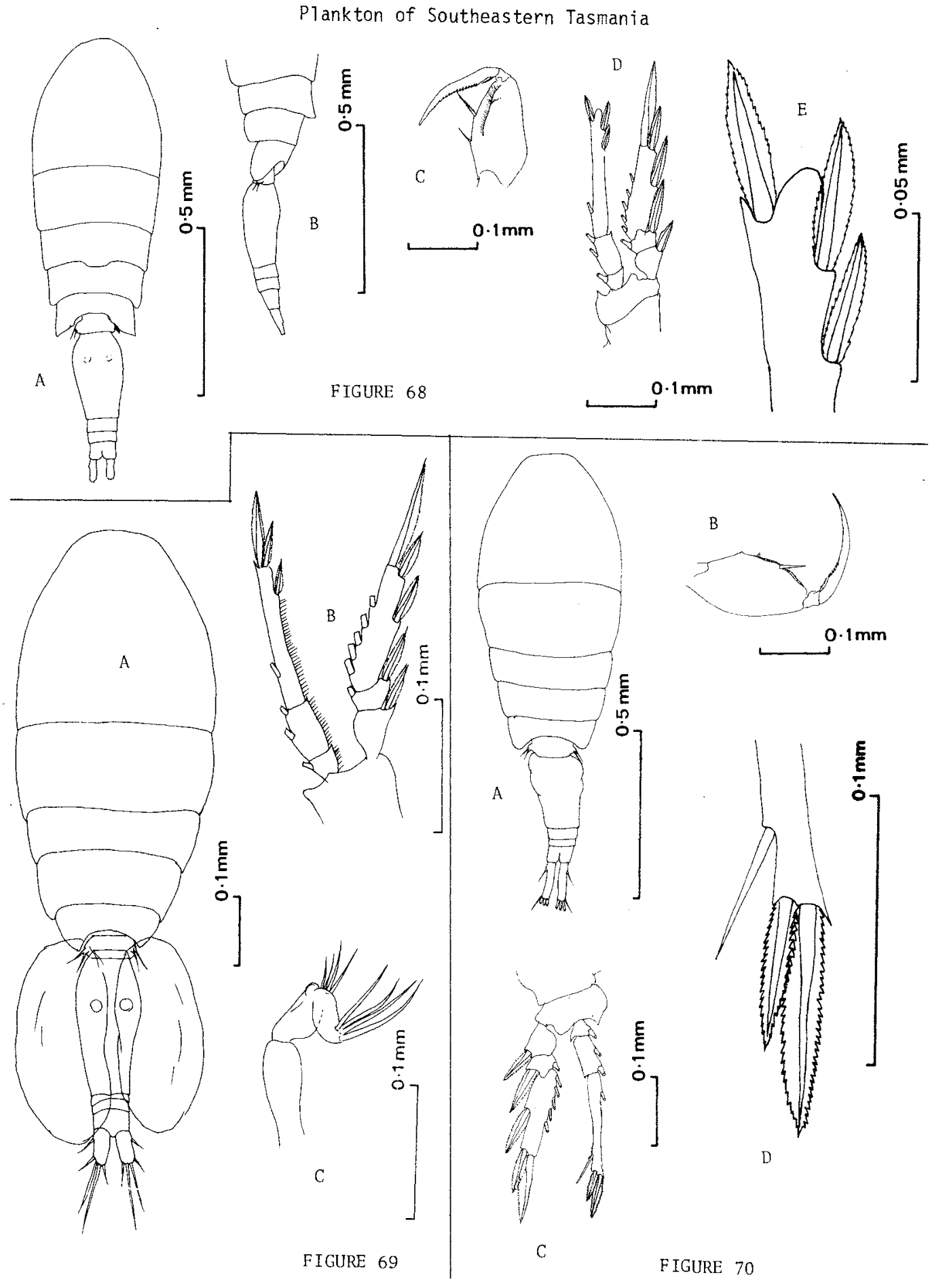


Nyan Taw

Previous Tasmanian Records: Ni1.

Occurrence: Inshore coastal (the occurrence of this species in the remaining areas was not determined due to the difficulties involved in identification.)

Figure Explanations:
(a) female whole animal, dorsal view,
(b) female rostrum, lateral view,
(c) female first leg,
(d) female second leg,
(e) female third leg,
(f) female fourth $1 \mathrm{eg}$.

Oithona tenuis Rosendorn, 1917

Previous Tasmanian Records: Nil.

$$
\text { (figs 67a - f) }
$$

Occurrence: Inshore coastal (the occurrence of this species in the remaining areas was not determined due to the difficulties involved in identification).

Figure Explanations:

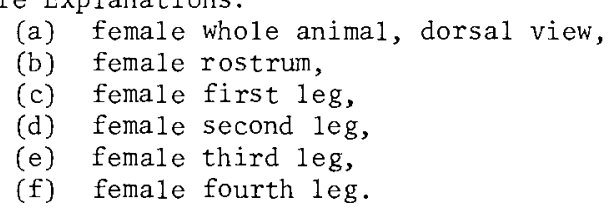

\section{Family ONCAEDIDAE}

Oncaea conifera Giesbrecht, 1891

(figs 68a - e)

Previous Tasmanian Records: South of Tasmania ( $44^{\circ} 05^{\prime} S, 147^{\circ} 35^{\prime} \mathrm{E}$ ) (Vervoort 1972). Occurrence: Coastal and Oceanic.

Figure Explanations:

(a) female whole animal, dorsal view,

(b) posterior portion of female metasome and urosome, lateral view,

(c) female maxilliped,

(d) female fourth leg,

(e) terminal portion of distal endopodite segment of female fourth leg.

Previous Tasmanian Records: Nil.

Oncaea media Giesbrecht, 1891

(figs 69a - c)

Occurrence: Inshore coastal, Coastal and Oceanic.

Figure Explanations:

(a) female whole animal, dorsal view,

(b) female fourth leg,

(c) female second antenna.

Oncaea mediterronea (Claus, 1863)

(figs $70 \mathrm{a}-\mathrm{d}$ )

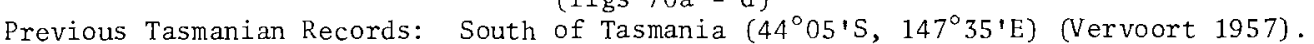
Occurrence: Coastal and oceanic.

Figure Explanations:

(a) female whole animal, dorsal view,

(b) female maxilliped,

(c) female fourth $1 \mathrm{eg}$,

(d) terminal portion of distal endopodite segment of female fourth leg. 
Previous Tasmanian Records: Nil.

$$
\text { (figs } 71 \mathrm{a}-\mathrm{f} \text { ) }
$$

Occurrence: Inshore coastal, Coastal and Oceanic.

Figure Explanations:

(a) female whole animal, dorsal view,

(b) terminal portion of distal endopodite segment of female fourth leg,

(c) terminal portion of distal endopodite segment of female third leg,

(d) female maxilliped,

(e) male maxilliped,

(f) male urosome, dorsal view.

\section{Order HARPACTICOIDA}

\section{Family TACHIDIIDAE}

Euterpina acutifrons (Dana, 1852)

Previous Tasmanian Records: Nil.

$$
\text { (figs } 72 a-f)
$$

Occurrence: Estuarine and Inshore coastal.

Figure Explanations:
(a) female whole animal, dorsal view,
(b) female fifth leg,
(c) male whole animal, lateral view,
(d) male first antennae,
(e) male second antennae,
(f) male fourth leg.

\section{Sub-C lass MALACOSTRACA}

\section{Order EUPHAUSIACEA}

Euphausia Zucens (Hansen, 1905)

$$
\text { (figs 73a - c) }
$$

Previous Tasmanian Records: Water around Tasmania (John 1936; Bradbury 1972). Occurrence: Coastal and Oceanic.

Figure Explanations:
(a) adult female whole animal, lateral view,
(b) anterior part of carapace and antennal peduncles of adult female, lateral view,
(c) adult male copulatory organ.

\section{Euphousia recurva Hansen, 1905}

$$
\text { (figs } 74 a-c)
$$

Previous Tasmanian Records: Northwest of Tasmania (Bradbury 1972). Occurrence: Coastal and Oceanic.

Figure Explanations:
(a) adult female whole animal, lateral view,
(b) anterior part of carapace and antennal peduncles of adult female, lateral view,
(c) adult male copulatory organ. 


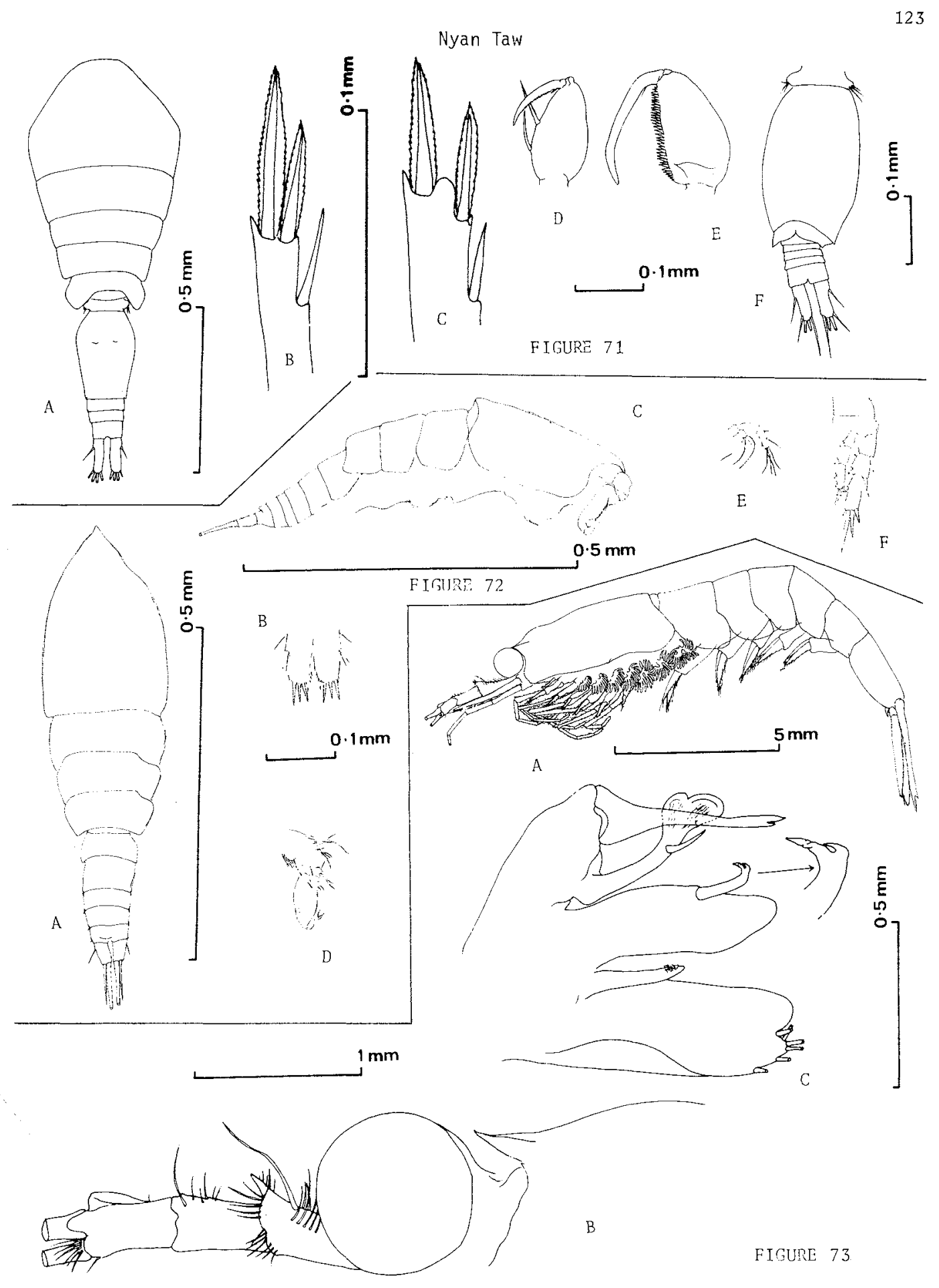


Plankton of Southeastern Tasmania
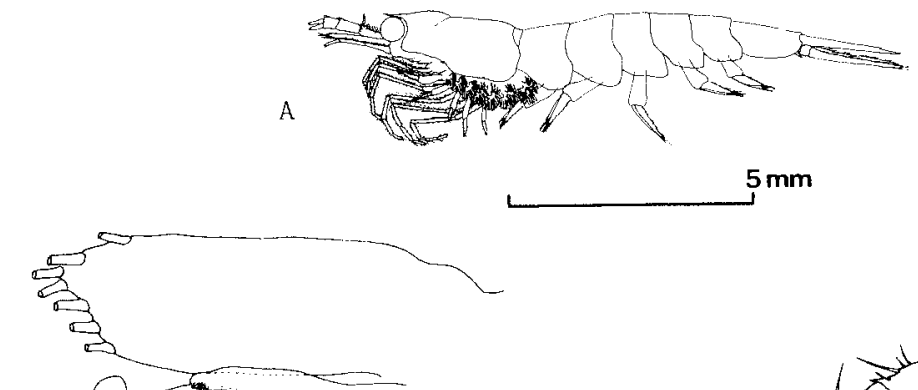

C

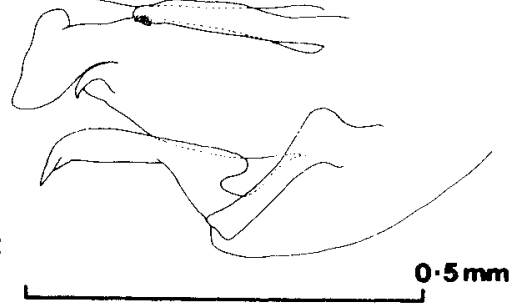

$0.5 \mathrm{~mm}$

FIGURE 74
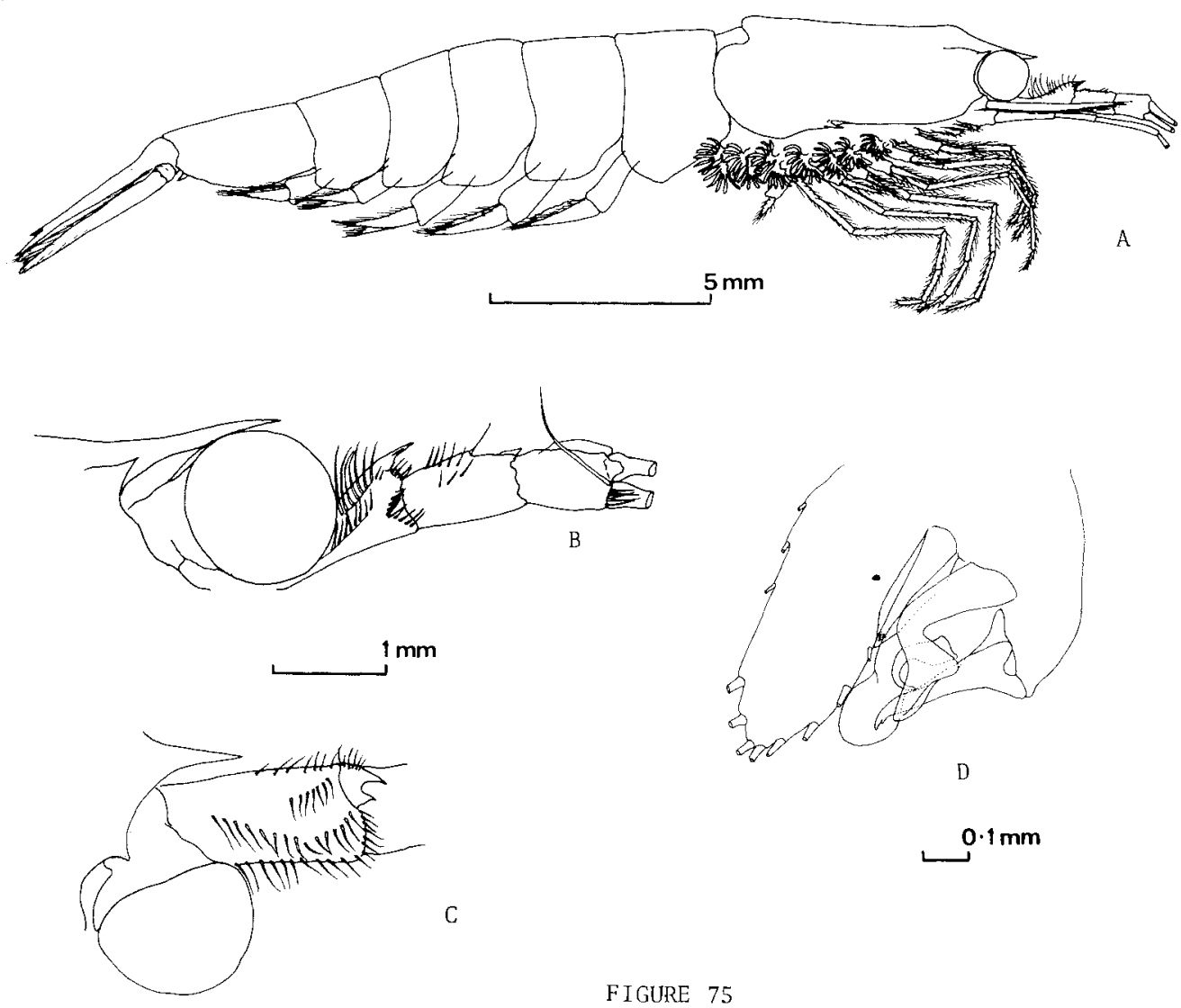

FIGURE 75 


\section{Nyan Taw}

\section{Euphausia simizis (Sars, 1885) \\ (figs $75 a-d)$}

Previous Tasmanian Records: South and eastern waters of Tasmania (John 1936; Bradbury 1972).

Occurrence: Station E 6, May, 1973 - 2 females, 2 males and 1 juvenile.

Figure Explanations:

(a) adult male whole animal, 1ateral view,

(b) anterior part of carapace and antennal peduncles of adult male, lateral

(c) and dorsal view,

(d) adult male copulatory organ.

\section{Euphausia similis var. armata (Hansen, 1905)}

(figs $76 a-c)$

Previous Tasmanian Records: Waters around Tasmania (John 1936; Bradbury 1972);

Southwestern Tasmania (Sheard 1953).

Occurrence: Station E 6, November, 1971 - 8 females and 11 juveniles.

Station E 6, May, 1973 - 8 females, 2 males and 5 juveniles.

Figure Explanations:

(a) adult female whole animal, lateral view,

(b) adult male copulatory organ,

(c) female tooth on the mid-dorsal posterior margin of the third abdominal segment.

\section{Euphausia Zongirostris (Hansen, 1905)}

(figs $77 a-c)$

Previous Tasmanian Records: Southwest of Tasmania (Sheard 1953); South of Tasmania (Bradbury 1972).

Occurrence: Station E 6, May, 1973-1 adult female.

Figure Explanations:

(a) adult female whole animal, lateral view,

(b) anterior part of carapace and antennal peduncles of adult female,

(c) dorsal and lateral views.

Nyctiphanes australis Sars, 1885

Previous Tasmanian Records: Ni1.

Occurrence: Inshore coastal and Coastal.

Figure Explanations:

(a) adult female whole animal, lateral view,

(b) adult male copulatory organ,

(c) anterior part of carapace and antennal peduncle of adult female, lateral view.

\section{Nematoscelis megalops Sars, 1885}

(figs $79 a-d$ )

Previous Tasmanian Records: Water around Tasmania (Bradbury 1972).

Occurrence: Coastal and Oceanic.

Figure Explanations:

(a) adult female whole animal, lateral view,

(b) terminal segment of second thoracic leg,

(c) spine of the terminal segment of second thoracic leg,

(d) pre-anal spine.

Thysonoessa gregaria Sars, 1885

Previous Tasmanian Records: Ni1.

(figs $80 a-e)$

Occurrence: Coastal and Oceanic. 


\section{Plankton of Southeastern Tasmania}

Figure Explanations:

(a) adult female whole animal, lateral view,

(b) distal segments of female second thoracic leg,

(c) adult male copulatory organ,

(d) adult female pre-anal spine,

(e) adult male pre-anal spine.

Sub-Class EUCARIDA

Order DECAPODA

Family SERGESTIDAE

Lucifer hanseni (Nobili, 1905)

(figs $81 \mathrm{a}-\mathrm{e}$ )

Previous Tasmanian Records: Derwent Estuary (Ong 1967).

Occurrence: Inshore coastal (the occurrence in the coastal and oceanic waters was not determined).

Figure Explanations:

(a) female whole animal, lateral view,

(b) male last abdominal segment and telson, lateral view,

(c) male telson, lateral view,

(d) male telson, dorsal view,

(e) male copulatory organ

Phy lum CHAETOGNATHA

Eukrohnia hamata (Mobius, 1875)

(figs $82 \mathrm{a}-\mathrm{c}$ )

Previous Tasmanian Records: Eastern coastal waters (Thomson 1947).

Occurrence: Station E 1, November, 1972 - 1 specimen.

Figure Explanations:

(a) whole anima1, ventral view,

(b) detail structure of head, ventral view,

(c) detail structure of the eyes, dorsal view.

\section{Pterosagitta draco (Krohn 1853)}

(fig. 83)

Previous Tasmanian Records: Eastern Coastal waters (Thomson 1947).

Occurrence: Coastal and Oceanic.

Figure Explanation: whole animal, ventral view.

\section{Sagitta gazellae (Ritter-Zahony, 1909)}

(fig. 84)

Sagitta gazelzae, David, 1955, pp. 244-254, figs. 1, 5a and b, 6b-e.

Previous Tasmanian Records: Eastern waters of Tasmania (David 1955; Thomson 1947 ?).

Occurrence: Coastal and Oceanic.

Figure Explanation: whole animal, ventral view.

Sagitta Zyra (Krohn, 1853)

(fig. 85)

Previous Tasmanian Records: Nil.

Occurrence: Coastal and Oceanic.

Figure Explanation: whole anima1, ventral view. 
Nyan Taw

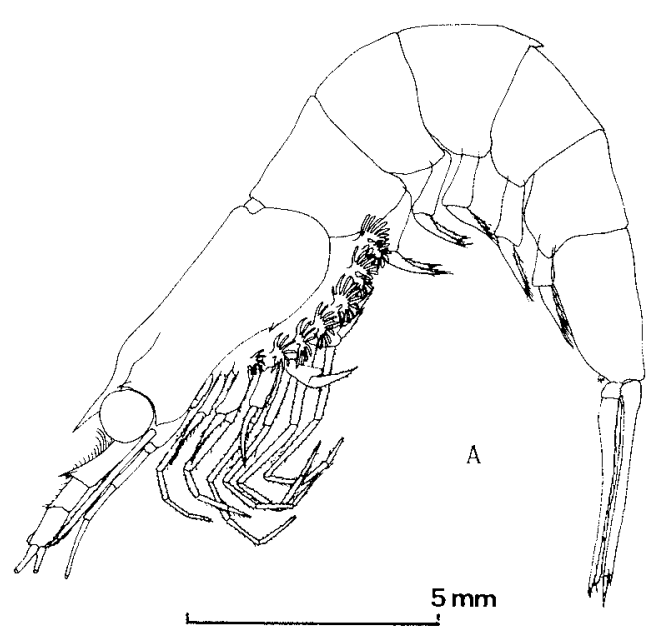

FIGURE 76
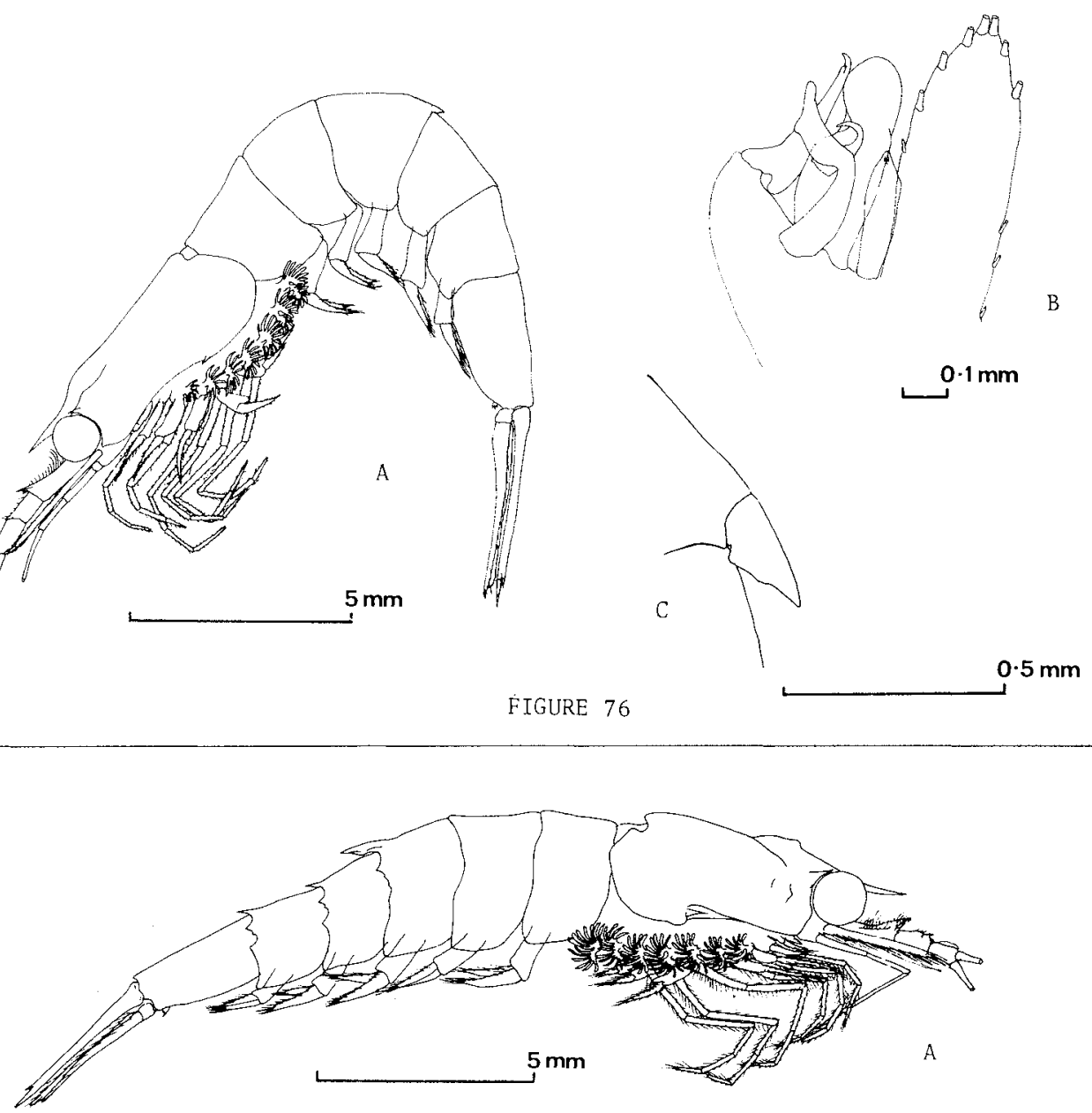

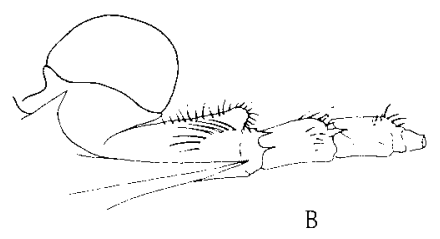

$1 \mathrm{~mm}$

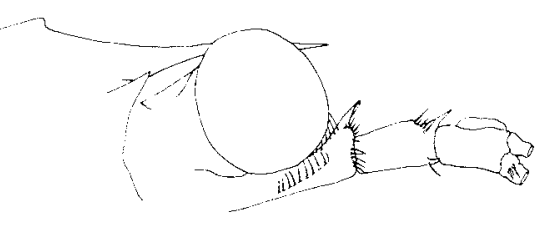

C

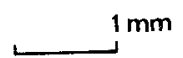

FIGURE 77 


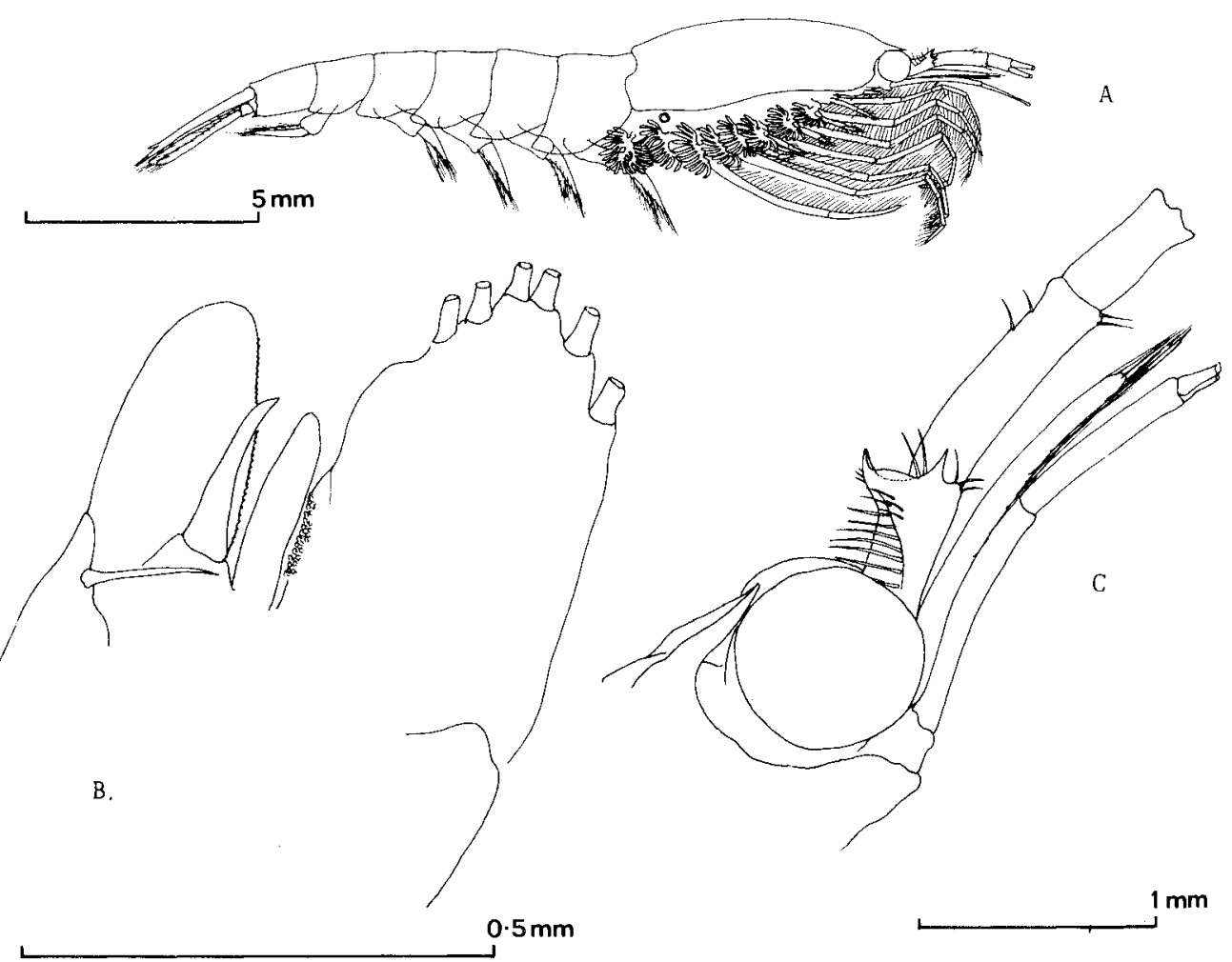

FIGURE 78

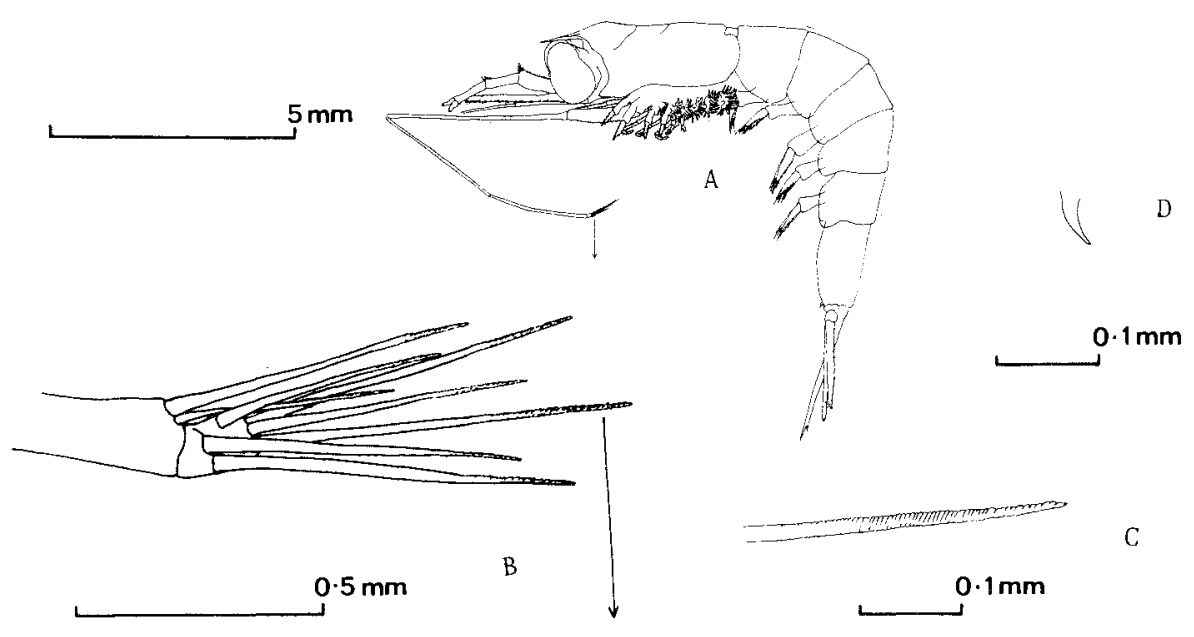

FIGURE 79 


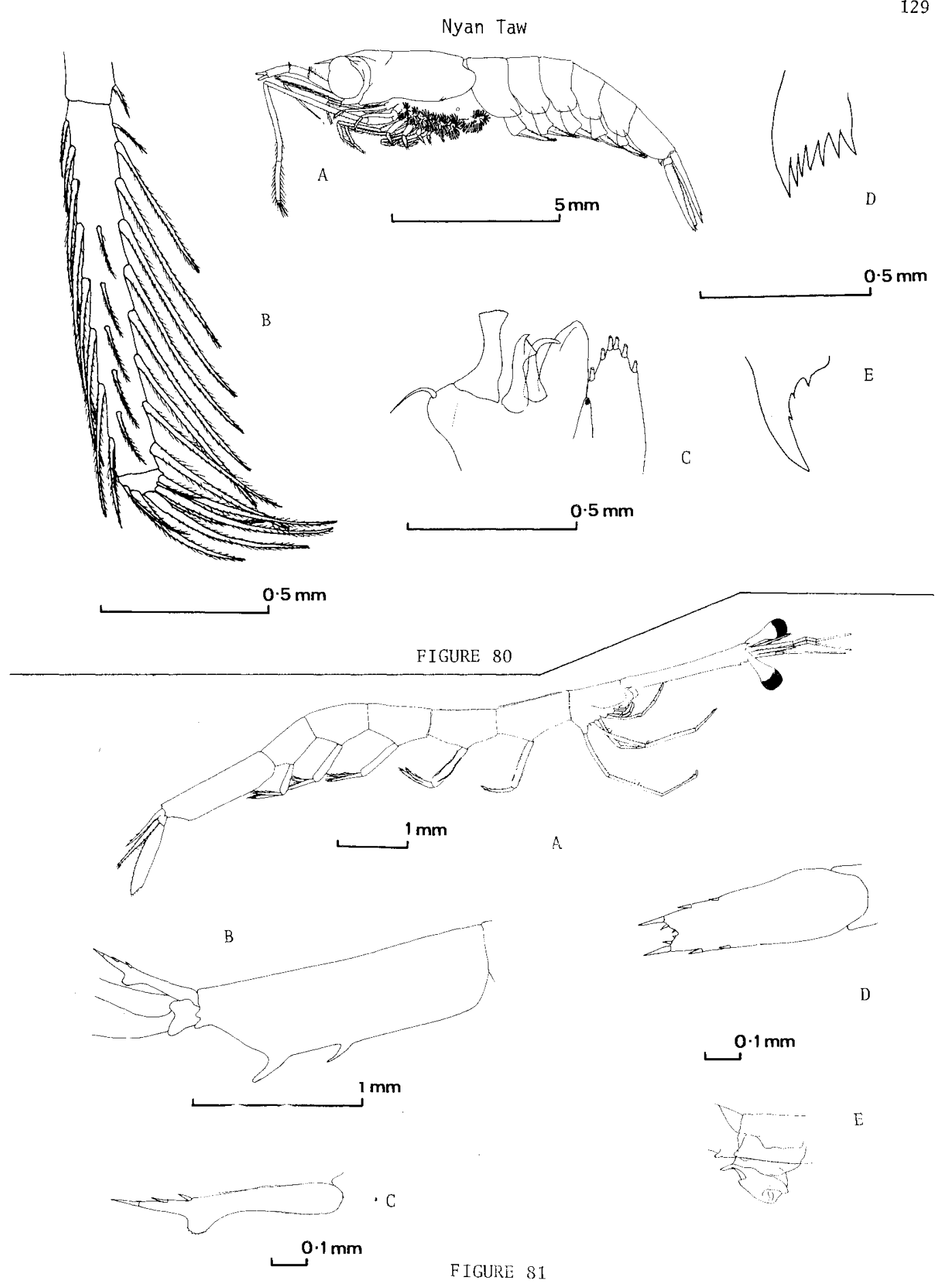


Plankton of Southeastern Tasmania
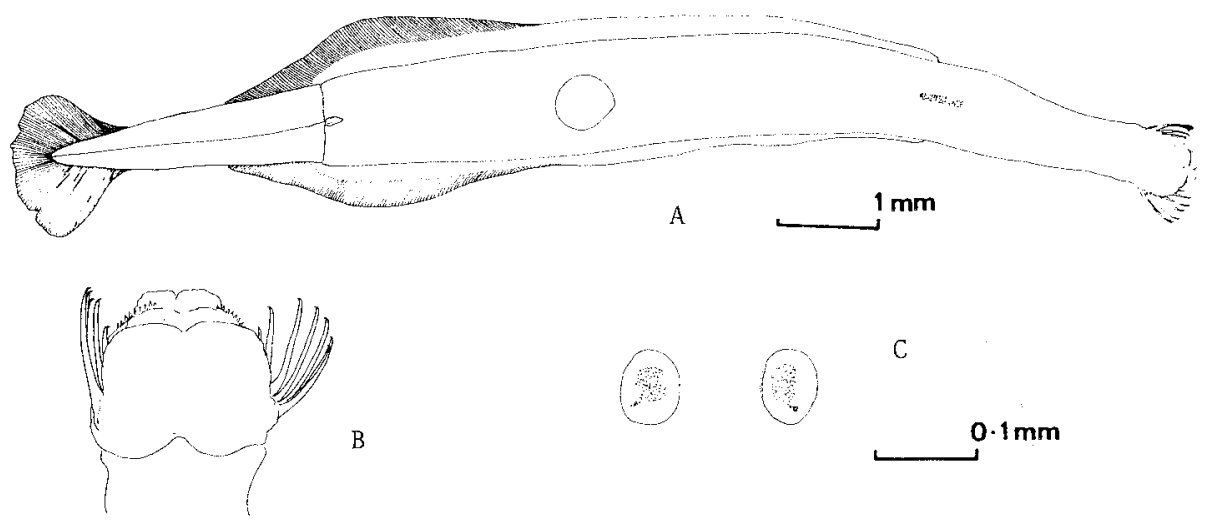

$0.5 \mathrm{~mm}$

F IGURE 82

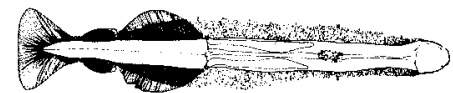

FIGURE 83
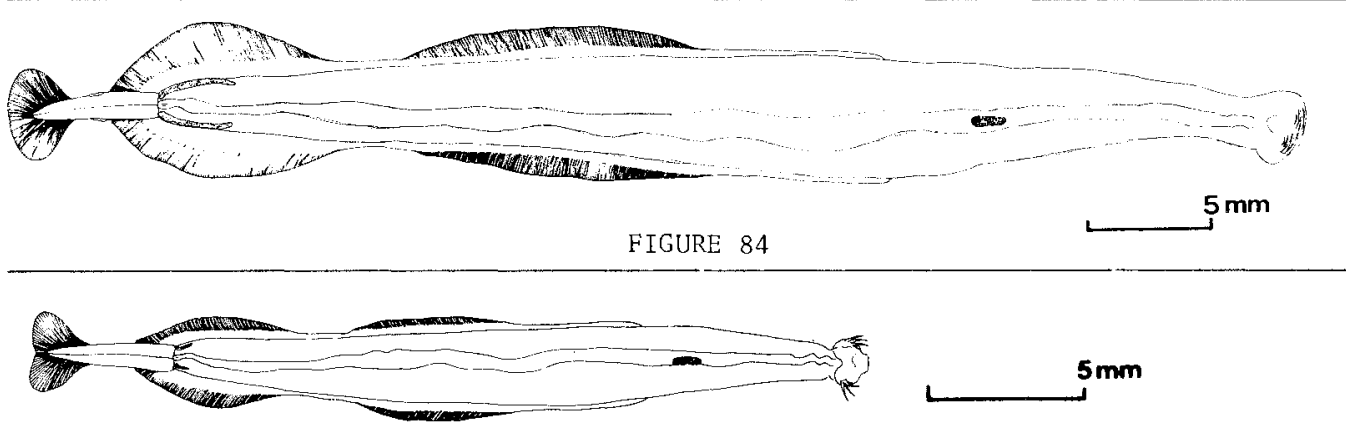

FIGURE 85

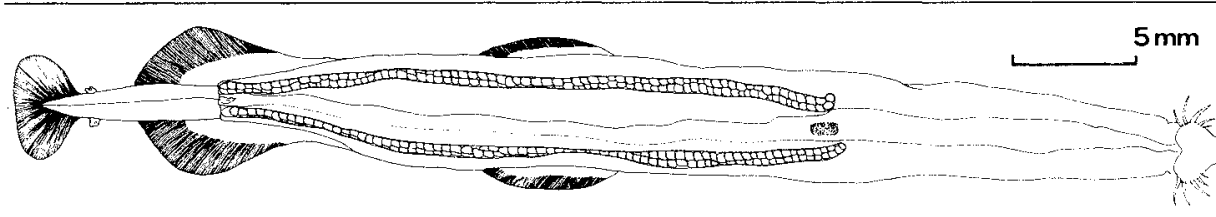

FIGURE 86

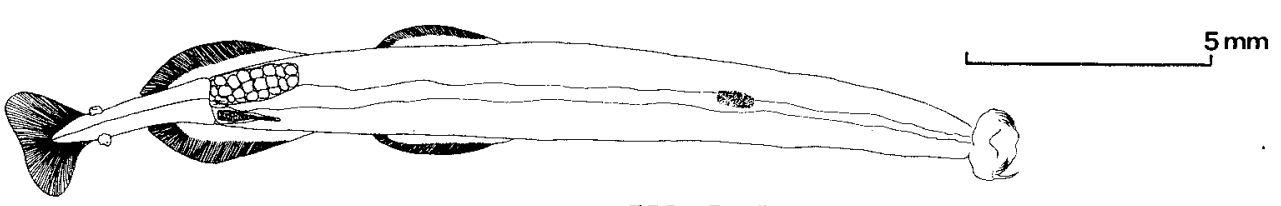

FIGUPE 87 
Nyan Taw

Sagitta hexaptexa (D'Orbigny, 1853)

(fig. 86)

Previous Tasmanian Records: Eastern coastal waters (Thomson 1947).

Occurrence: Station E 11, August, 1971 - 3 specimens

Station E 1, March, 1972 - 1 specimen

Station E 7, April, 1972 - 1 specimen

Station E 10, May, $1973-1$ specimen

Figure Explanation: whole anima1, ventral view.

Previous Tasmanian Records: Nil.

$$
\begin{gathered}
\text { Sagitta enflata (Grassi, 1881) } \\
\text { (fig. 87) }
\end{gathered}
$$

Occurrence: Station E 4, November, 1972 - 1 specimen.

Figure Explanation: whole anima1, ventral view.

Sagitta serratodentata tasmanica Thomson, 1947

(figs $88 \mathrm{a}-\mathrm{b}$ )

Previous Tasmanian Records: Eastern coastal waters (Thomson 1947). Occurrence: Inshore coasta1, Coastal and Oceanic.

Figure Explanations:

(a) whole animal, ventral view,

(b) seminal vesical.

\section{Sagitta serratodentata atzontica Tokioka, 1940}

(fig. 89)

Previous Tasmanian Records: Nil.

Occurrence: Station E 6, November, 1971.

Figure Explanation: seminal vesical.

\section{Sagitta planctonis (Steinhaus, 1896)}

(fig. 90)

Previous Tasmanian Records: Eastern Coastal waters (Thomson 1947; David 1956). Occurrence: Coasta1 and Oceanic.

Figure Explanation: whole animal, ventral view.

$$
\begin{aligned}
& \text { Sagitta minima (Grassi, 1881) } \\
& \text { (fig. 91) }
\end{aligned}
$$

Previous Tasmanian Records: Eastern coastal waters (Thomson 1947).

Occurrence: Estuarine, Inshore coastal, Coastal and Oceanic.

Figure Explanation: whole animal, ventral view.

$$
\begin{gathered}
\text { Sagitta guileri Nyan Taw, } 1975 \\
\text { (figs 92a - g) }
\end{gathered}
$$

Previous Tasmanian Records: Nyan Taw (1975a).

Occurrence: Estuarine and Inshore coastal.

Figure Explanations:

(a) whole animal, ventral view,

(b) ventral view of anterior region of the head, showing anterior and posterior teeth,

(c) detail structure of eye,

(d) detail structure of third right (counted from ventral side) hook,

(e) detail structure of distal region of third right hook,

(f) mature seminal vesicle,

(g) mature seminal vesicle (bursting). 


\title{
Plankton of Southeastern Tasmania
}

Phy lum TUNICATA

C1ass ACOPA or CADUCICHORDATA

\author{
Order PYROSOMIDA
}

Pyrosoma atzanticum atzanticum (Peron, 1804)

Previous Tasmanian Records: Eastern coastal waters (Thomson 1948).

Occurrence: Inshore coastal, Coastal and Oceanic.

Order CYCLOMYARIA

On1y oozooid stages (e.g. fig. 93) were taken in the present study.

Order DESMOMYARIA

Thetys vagina (Tilesius, 1802)

(fig. 94)

Previous Tasmanian Records: Waters around Tasmania (Thompson 1948, 1954).

Occurrence: Station E 5, June, 1972 - 5 Aggregate forms

Station E 7, June, 1972 - 12 Aggregate forms

Station E 9, June, 1972 - 3 Aggregate forms

Figure Explanation: aggregate form.

\section{Iasis zonaria (Pa11as, 1774)

$$
\text { (figs } 95 a-b)
$$

Previous Tasmanian Records: Waters around Tasmania (Thompson 1948, 1954).

Occurrence: Station E 3, November, 1971 - 8 Aggregate forms

Station E 4, December, 1971 - 7 Aggregate forms

Station E 1, March, 1972 - 1 solitary form, 4 Aggregate forms. Figure Explanations:

(a) solitary form, dorsal view,

(b) aggregate form, dorsal view.

Thalia democratica (Forska1, 1775)

$$
\text { (figs } 96 \mathrm{a}-\mathrm{b} \text { ) }
$$

Previous Tasmanian Records: Eastern coastal waters (Thompson 1948).

Occurrence: Station E 10, October, 1972 - 2 Aggregate forms

Station $E$ 7, November, 1972 - 2 Aggregate forms, 1 solitary form Figure Explanations:

$$
\text { Station E 9, November, } 1972 \text { - } 3 \text { Aggregate forms }
$$

(a) solitary form, dorsal view,

(b) aggregate form, dorsal view.

$$
\begin{gathered}
\text { Salpa fusiformis Cuvier, } 1804 \\
\text { (figs } 97 \mathrm{a} \text { - b) }
\end{gathered}
$$

Previous Tasmanian Records: Waters around Tasmania (Thompson 1948, 1954).

Occurrence: Inshore coastal, Coastal and Oceanic.

Figure Explanations:

(a) aggregate form, ventral view,

(b) solitary form, dorsal view. 
Nyan Taw
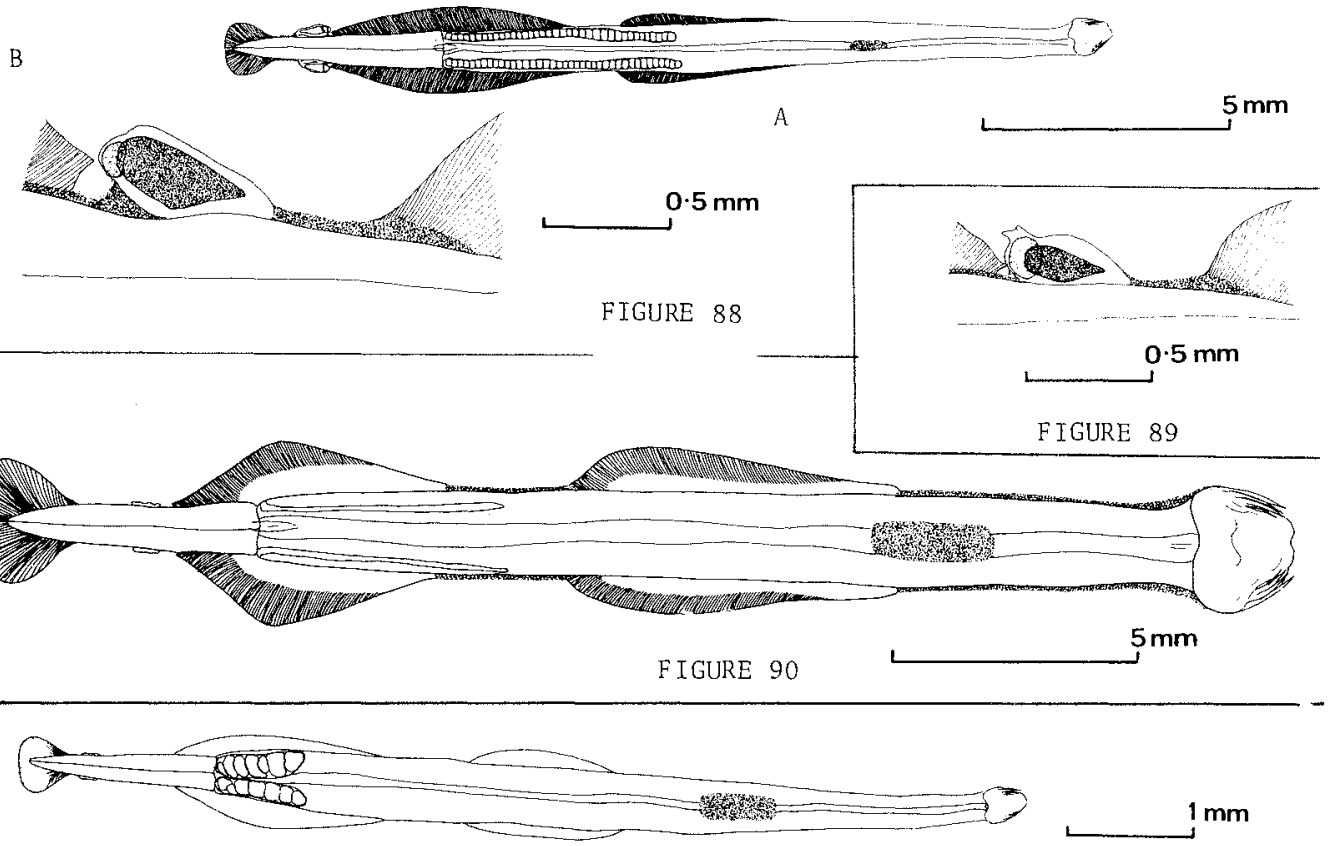

FIGURE 91
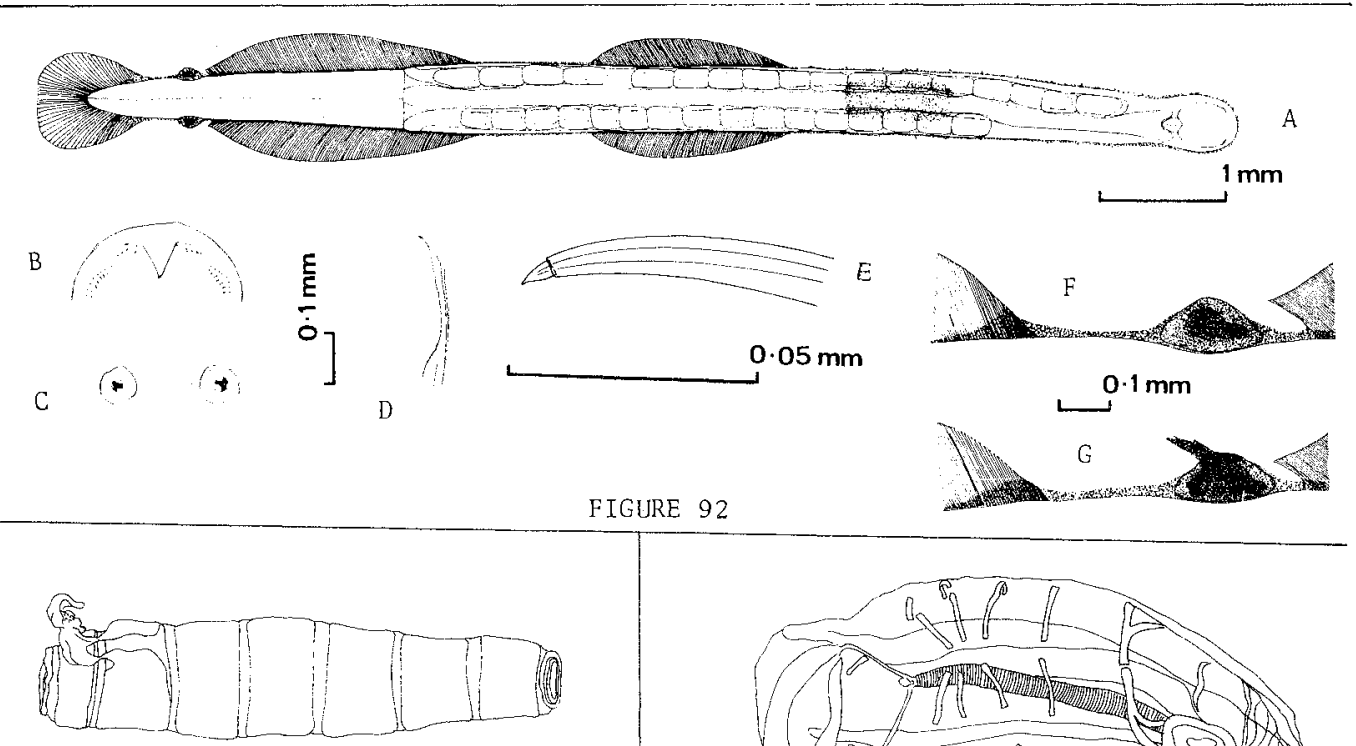

$5 \mathrm{~mm}$

FIGURE 93

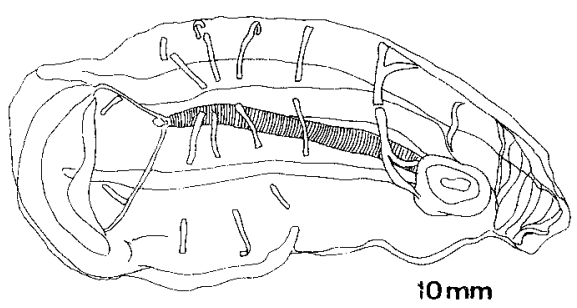

F IGURE 94 


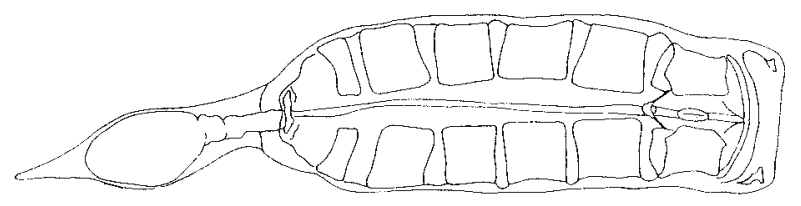

A
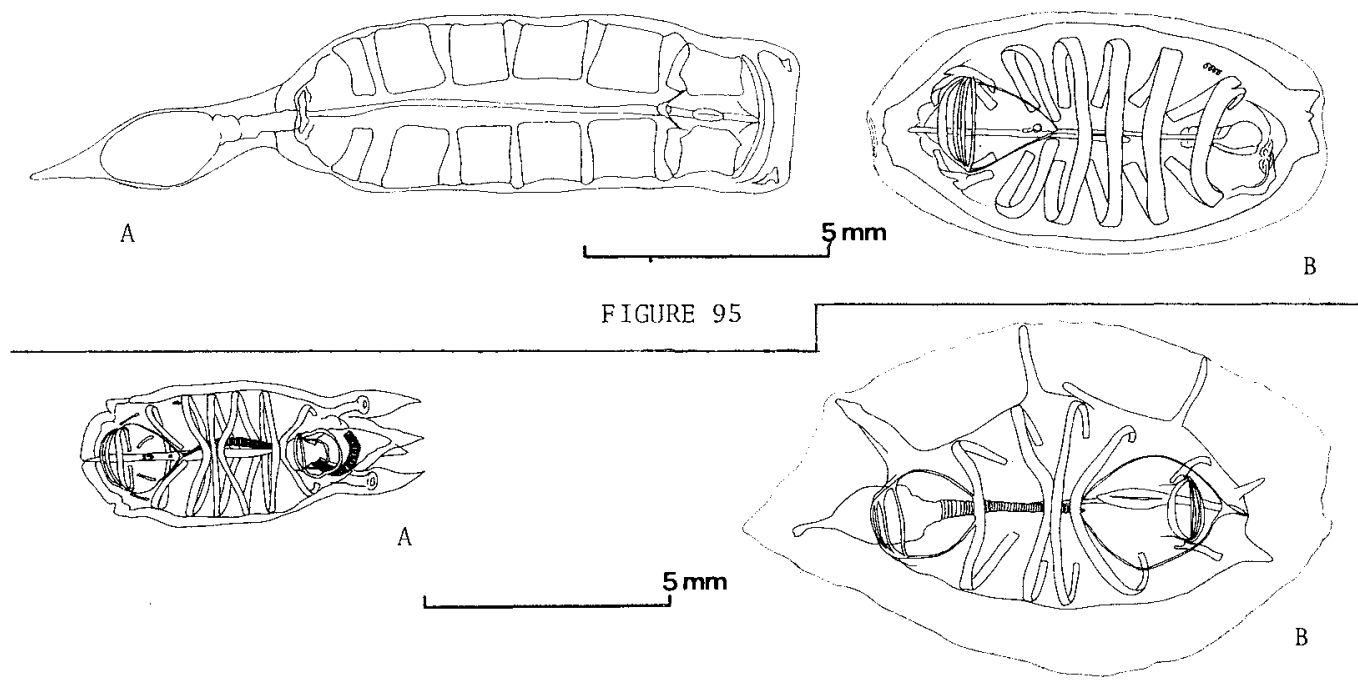

FIGURE 96

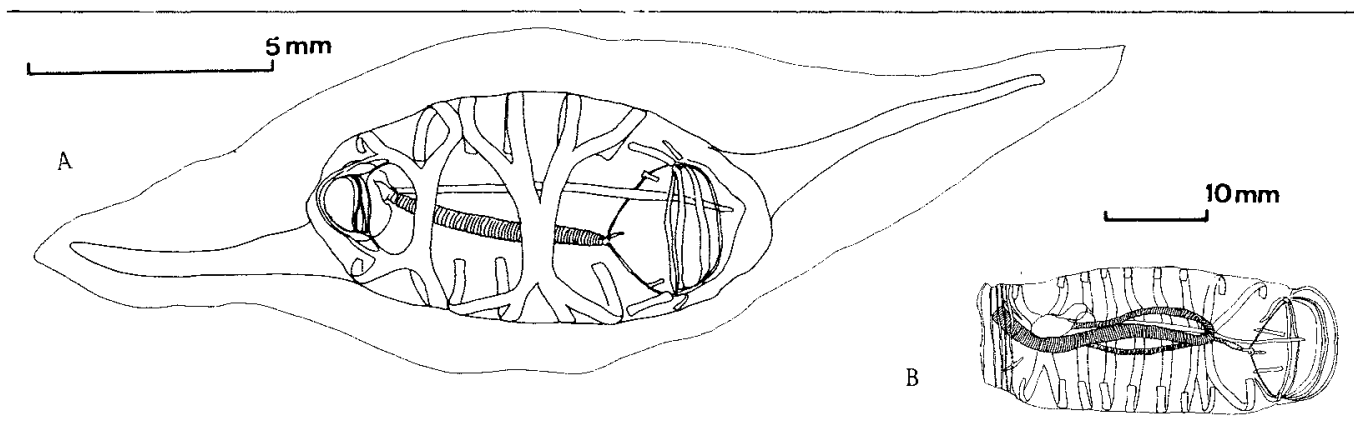

F IGURE 97
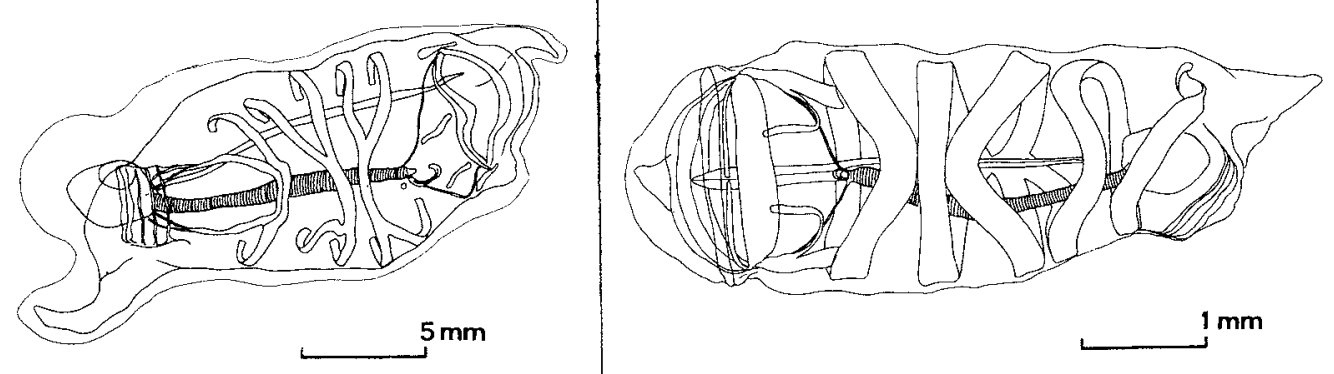

FIGURE 98

FIGURE 99 
Nyan Taw

Salpa maxima (Forska1, 1775)

(fig. 98)

Previous Tasmanian Records: Eastern coastal waters (Thompson 1948).

Occurrence: Inshore coastal, Coastal and Oceanic.

Figure Explanation: aggregate form, dorsal view.

Ihlea magathanica (Apstein, 1894)

(fig. 99)

Previous Tasmanian Records: Eastern coastal waters (Thompson 1948).

Occurrence: Inshore coastal, Coastal and Oceanic.

Figure Explanation: aggregate form, dorsal view.

\section{ACKNOWLEDGEMENTS}

I would sincerely like to thank the following:

Dr. E.R. Guiler for his encouragement and critical examination of the manuscript; Professor B. Johnson and Dr. J.L. Hickman for their encouragement and keen interest in the work; the skipper of the Zoology Department Research Vessel Neotrigonia; Mr. Tas Sward for his help in the field; Miss Khin Khin U for bringing to my attention an unrecorded copepod specimen; and to the staff and members of Zoology Department, University of Tasmania for their help in many ways.

Dr. A.G. Nichols for his helpful advice on the taxonomic work on the copepods in the early stages; Dr. D.J. Tranter and Mr. F.B. Griffiths of the Division of Fisheries and Oceanography, CSIRO, Cronulla for the loan of some reference specimens; Dr. T. Dix, Sea Fisheries Division, Tasmanian Department of Agriculture, for the permission to study the zooplankton samples; Mr. D.C. Wolfe for his help in the field and in the Sea Fisheries Laboratory.

This work has been carried out while the author held a Colombo Plan Fellowship for which he is grateful.

\section{REFERENCES}

Bayly, I.A.E., 1964: A revision of the Australasian species of the freshwater genera Boeckelza and Hemiboeckelza (Copepoda: Calanoida). Aust. J. mar. freshwat. Res., $15,180-238$.

Bradbury, J.H., 1972: Seasonal distribution of Euphausidae in the Southern Ocean adjacent to Australia. M. Sc. Thesis, University of Adelaide.

Bradford, J.M., 1970: Records of pelagic copepods off Kaikoura, New Zealand. N.Z. J. mar. freshwat. Res., 4(4), 351-363.

1972: Systematics and Ecology of New Zealand Central East Coast

Plankton Sampled at Kaikoura. Bul2. N.Z. Dep. Scient. Ind. Res., 207, 89.

, 1976: Partial revision of the Acartia sub-genus Acartiura (Copepoda:

Calanoidea: Acartiidae). N.Z. J. mar. freshw. Res., 10, 159-202.

Brehm, V., 1953: Contribution to the freshwater microfauna of Tasmania. Pap. Proc. R. Soc. Tasm., 87, 33-62.

Brodsky, K.A., 1959: On the phylogenetic relations of some Calonus (Copepoda) species of the Northern and Southern Hemisphere. Zooz. Zh., 33, 1537-1553 (in Russian). , 1961: Comparison of Calanus species (Copepoda) from the Southern and Northern Hemispheres. Inf. Ser. N.Z. Dep. scient. ind. Res., 33, 22pp.

Dakin, W.J. and Colefax, A.N., 1933: The Marine Plankton of the Coastal Waters of New South Wales. 1. The chief planktonic forms and their seasonal distribution. Proc. Linn. Soc. N.S.W., 58, 186-222.

, 1940: The plankton of the Australian coastal waters off New South Wales. Part I. Monogr. Dept. Zool. Uni. Sydney, 1, 1-215.

David, P.M., 1955: The Distribution of Sagitta gazeZzae Ritter-Zahony. Discovery Rept., $27,235-278$. 
David, P.M., 1956: Sagitta plonctonis and related forms. Buzz. Brit. Mus. Nat. Hist., $4(8), 437-451$.

Farrañ, G.P., 1936: Copepoda. Scient. Rep. Gt. Barpier Reef Exped. 5(3), 73-142.

Guiler, E.R., 1955: Observation on the hydrology of the River Derwent, Tasmania. Pap. Proc. R. Soc. Tasm., 89, 65-80.

Heron, G.A. and Bowman, T.E., 1971: Postnaup1iar stages of the copepod crustaceans Clausocalanus Laticeps, C. brevipes and Ctenocalanus citer (Calanoida: Pseudocalanidae). BIOLOGY OF THE ANTARCTIC SEAS IV: Antarctic Research Series. (Eds. George A. L1ano and I. Eugene Wa1len.) 17, 141-165. (American Geophysical Union: Washington, D.C.)

Jillett, J.B., 1971: Zooplankton and Hydrology of Hauraki Gulf, New Zealand. BuZZ. N.Z. Dep. scient. ind. Res., 204, $103 \mathrm{pp.}$

John, D.D., 1936: The southern species of the genus Euphausia. Discovery Rept., 14, 193-325.

Kott, P., 1957: Zooplankton of east Australian waters. Rept. CSIRO Div. Fisheries \& Oceconogrophy, 14, 1-31.

Miller, A.R., 1950: A study of mixing processes over the edge of the Continental She1f. J. mar. Res., 9(2), 145-160.

Nichol1s, A.G., 1944: Littoral Copepoda from South Australia (II) Calanoida, Cyclopoida, Notodelphyoida, Monstrilloida and Caligoida. Rec. South Austr. Mus., $8,1-62$.

$11,501-514$

Nyan Taw, 1974: A new Species of Labidocera (Copepoda: Calanoida) from Tasmania and its Postnaupliar Developmental Stages. Aust. J. mor. freshwat. Res., 25(2), $261-272$.

1975a: A new Species of Sagitta (Chaetognatha) from D'Entrecasteaux Channel, Tasmania. Pap. Proc. R. Soc. Tasm., 109, 77-83.

b: Zooplankton and hydrology of the south east coastal waters of Tasmania. Ph.D. Thesis, University of Tasmania.

Ong, J.E., 1967: A general survey of primary productivity and the spatial and temporal distribution of the zooplankton of the surface waters of the Derwent River estuary. B.Sc. (Hons.) Thesis, University of Tasmania.

, 1970: Ultrastructural studies of the cephalosome of some maxine and estuarine Calanoid Copepods. Ph.D. Thesis, University of Tasmania.

Ong, J.E. and Lake, P.S., 1970: The ultrastructural morphology of the mid-gut diverticulum of the calanoid copepod Calanus helgolondicus (Claus) (Crustacea). Aust. J. Zoot., 18, 9-20.

Rose, M., 1933: Copepodes pelagiques. Ann. Inst. Oceanogr., Paris, 13, 117-133.

Sheard, K., 1953: Taxonomy, distribution and development of the Euphausiacea (Crustacea). Rep. B.A.N.Z. Antarct. Res. Exped., Ser. B., 8(1), 1-72.

Thomson, J.M., 1947: The Chaetognatha of Southeastern Australia. Bulz. Coun. seient. Ind. Res. Melb., 222, 1-43.

Thompson, H., 1948: PELAGIC TUNICATES OF AUSTRALIA. HANDBOOK. Cown. scient. Ind. Res. Meib., 196pp. $1(4), 183-5$.

Vervoort, W., 1957: Copepods from Antarctic and sub-Antarctic plankton samples. Rep. B.A.N.Z. Antaret. Res. Exped., 3(3), 1-160.

Wi1son, C.B., 1932: The Copepods of the Woods Hole Region, Mass. BuZZ. U.S. natn. Mus., 158, 635pp. 